\title{
CARACTERIZAÇÃO CITOLÓGICA E GENÉTICA DE LINHAGENS DE Aspergillus nidulans PORTADORAS DE DUPLICAÇÃO CROMOSSÔMICA E DO GENE bncA1
}

\author{
ÁGATA CRISTIANE HUPPERT GIANCOLI \\ Bióloga
}

Orientadora Profa. Dra. ALINE APARECIDA PIZZIRANI-KLEINER

Dissertação apresentada à Escola Superior de Agricultura "Luiz de Queiroz", Universidade de São Paulo, para obtenção do título de Mestre em Agronomia. Área de concentração: Microbiologia Agrícola.

\section{PIRACICABA}

Estado de São Paulo - Brasil

Junho -2000 


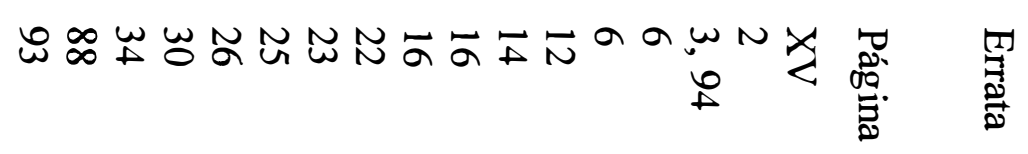

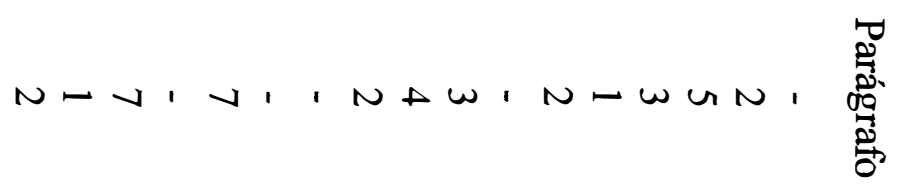
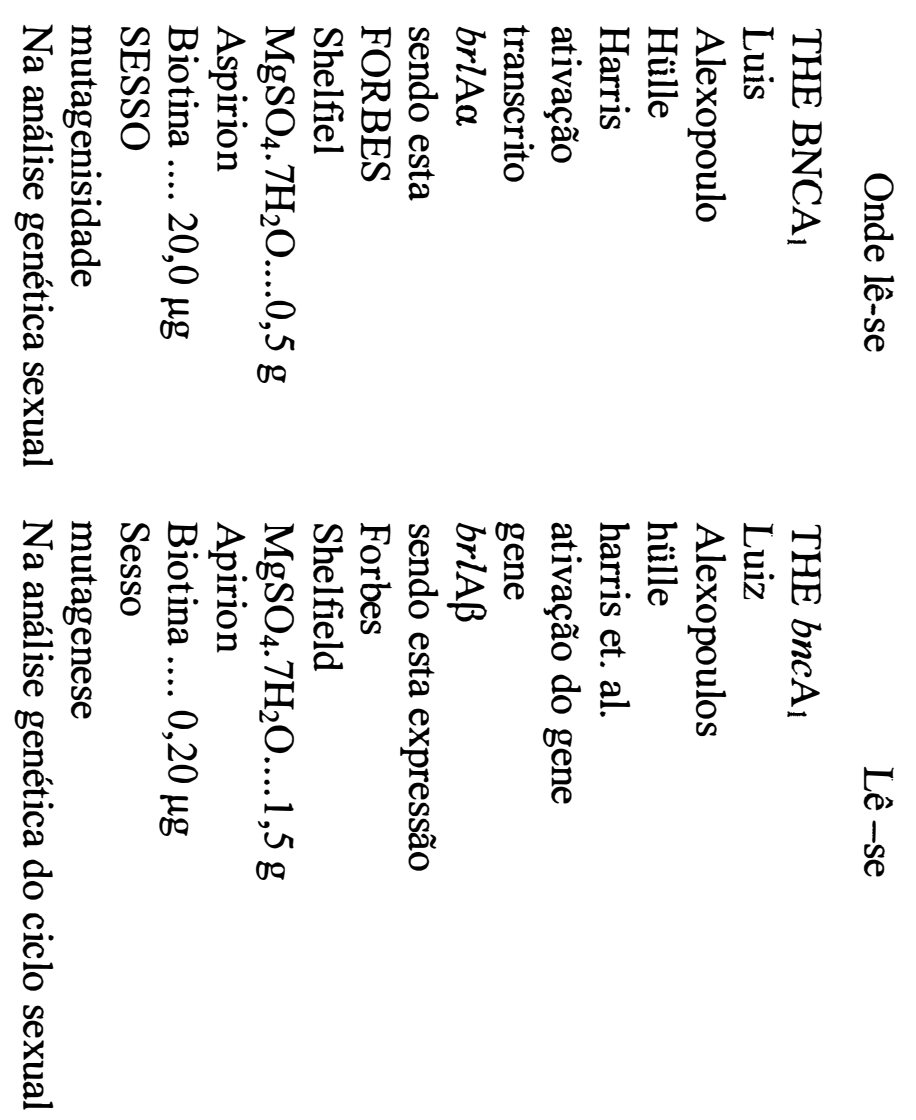
Dados Internacionais de Catalogação na Publicação (CIP) DIVISĀO DE BIBLIOTECA E DOCUMENTAÇĀO - Campus "Luiz de Oueiroz"/USP

\author{
Giancoli, Ágata Cristiane Huppert \\ Caracterizaçāo citológica e genética de linhagens de Aspergillus nidu/ans portadoras \\ de duplicaçāo cromossômica gene bncA 1 / Ágata Cristiane Huppert Giacoli. - - \\ Piracicaba, 2000. \\ 103 p. : il. \\ Dissertaçāo (mestrado) - - Escola Superior de Agricultura Luiz de Queiroz, 2000. \\ Bibliografia. \\ 1. Aspergilo 2. Ciclo de vida 3. Fungo 4. Gene 5. Genética do desenvolvimento \\ 6. Linhagem 7. Marcador genético 8. Mutaçāo 9. Regulaçāo genética I. Título
}

CDD 589.24

"Permitida a cópia total ou parcial deste documento, desde que citada a fonte -0 autor" 
Ivone Huppert Giancoli

Ofereço e Dedico

à Rodrigo, Flaviana e Herminio, pela constante ajuda éncentivo. 


\section{AGRADECIMENTOS}

- Profa. Dra. Aline Aparecida Pizzirani-Kleiner, pela orientação, amizade e confiança.

- Prof. Dr. João Lúcio de Azevedo, pelo auxilio nas discussões

- Prof. Dr. Walter Maccheroni Jr, pela amizade e sugestões.

- Aos profs. Dr. Elliot. Kitajima e Breno Leite, pela ajuda e sugestões para o desenvolvimento dos trabalhos de Microscopia Eletrônica no Núcleo de Apoio à Pesquisa - Microscopia Eletrônica Aplicada à Pesquisa Agropecuária NAPE/MEPA, da Escola Superior de Agricultura "Luiz de Queiroz" ESALQ/USP.

- Profa. Dra. Maria Helena Fungaro, pelas sugestões e correções.

- Professor Valter pelas correções.

- José Antônio da Silva (Zezo), pela amizade neste anos, e auxilio durante a execução da parte experimental.

- Graça e Silvania pela ajuda na Microscopia Eletrônica

- Elisabete Rodrigues e Carlos Macedonio, pela ajuda no processamento dos dados.

- As bibliotecárias da ESALQ, em especial Silvana (BG)

- À família Seraide pela acolhida

- Aos amigos do laboratório de Microrganismos, minha Segunda família, Fernando Barcelos, Wellington Araújo, Joelma Marcon, Rose Bueno, Estela, Paulo Lacava, Rudi, Ricardo Iara(זpa), Júlia, André, Cláudio, Margarete, Priscilla, Fernando, Danila, Cláudia, Marcelo, Rodrigo e Leonardo. 
- às amigas Cristiane, Rosangela, Luciana, Kalinca, Renato, Ricardo Mateus e Heiko pela convivência sempre agradável.

- Todos os funcionários e colegas do Departamento de Genética e Melhoramento de Plantas, pela acolhida

- Aos colegas do curso de Pós Graduação de Microbiologia Agrícola

- Aos professores dos cursos de Pós Graduação em Microbiologia Agrícola e Genética e Melhoramento de Plantas, por conduzir minha formação acadêmica.

- À Claudemir e Flaviana pela ajuda na digitalização da fotos

- À Capes pelo auxílio financeiro.

- Agradeço, Anafrain (Fanico), Vanderlei e Hermínio.

- Todos os anjos que acompanham meu caminho. 


\section{SUMÁRIO}

Página

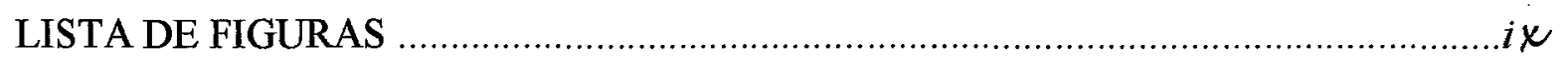

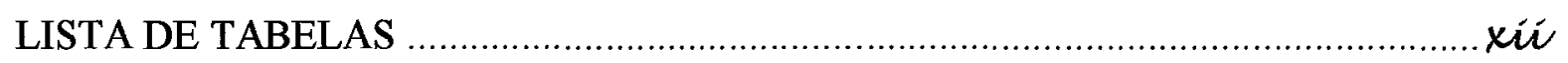

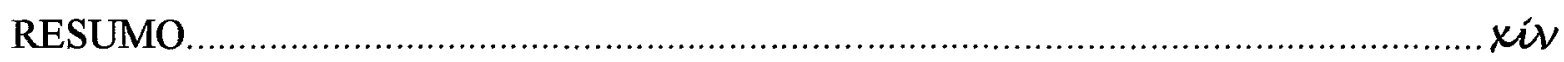

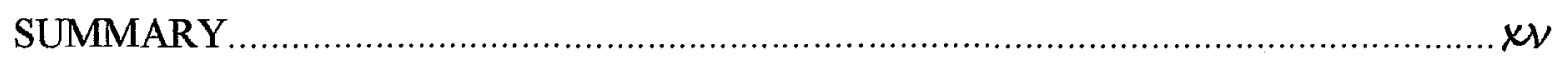

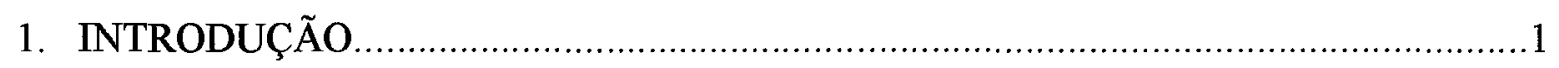

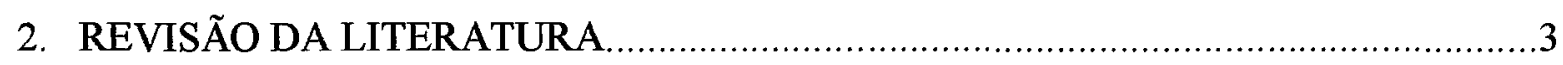

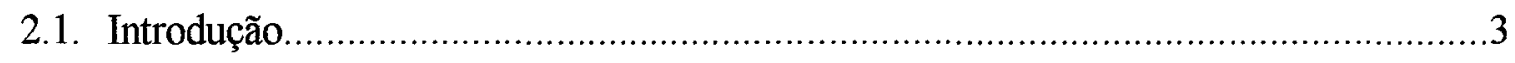

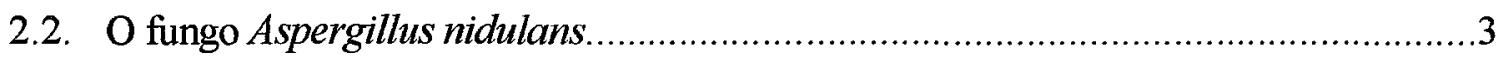

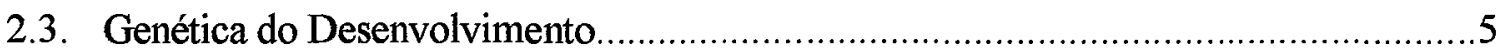

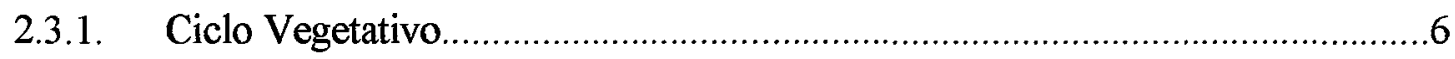

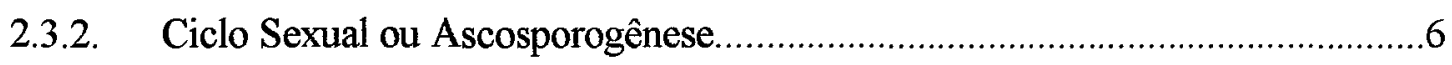

2.3.3. Ciclo Assexual ou Conidiogênese....................................................................

2.4. Aquisição da Competência.....................................................................................

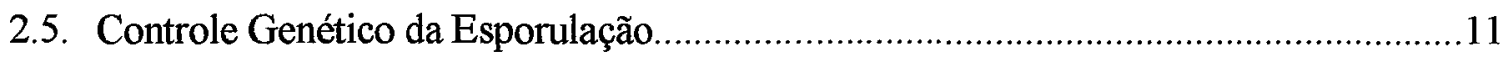

2.6. Relação entre o Ciclo Sexual e Assexual.....................................................................17

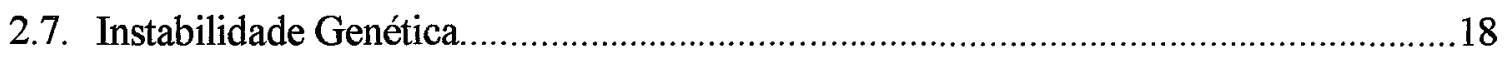

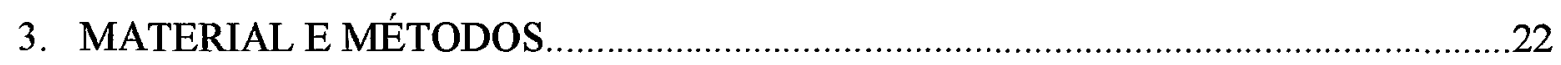

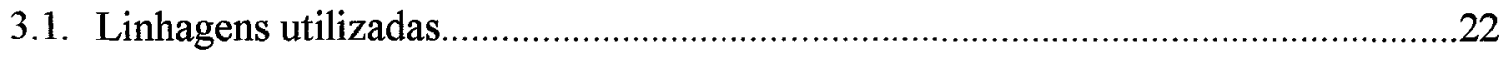

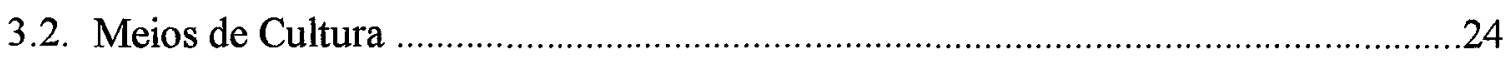

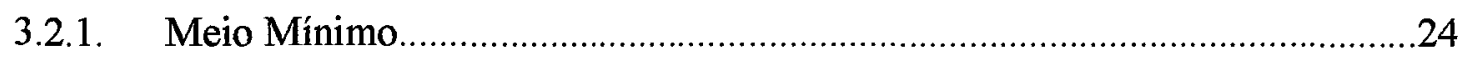




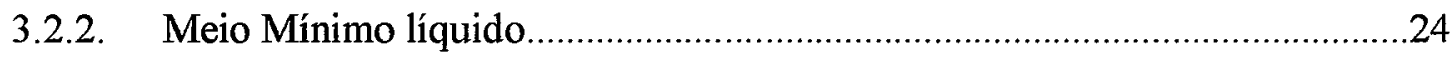

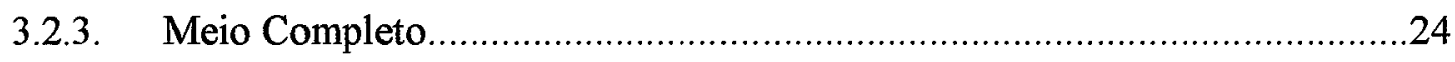

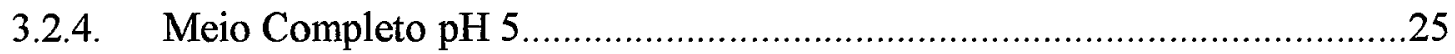

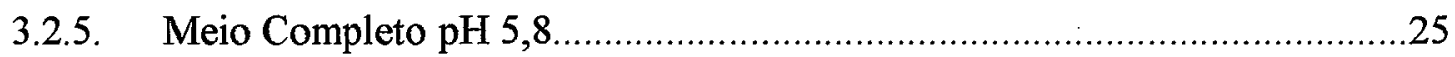

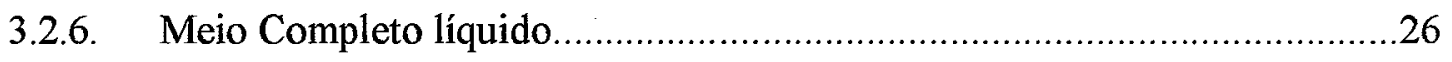

3.2.7. Meio Mínimo acrescido de 2\% de Meio Completo............................................

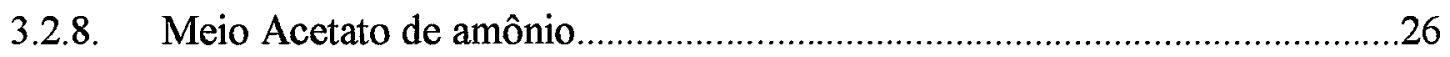

3.2.9. Meio de Galactose

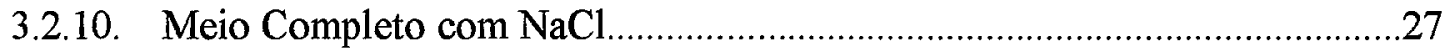

3.2.11. Meio Completo com solução de $\mathrm{KCl} 0,6 \mathrm{M}$ em tampão fosfato $\mathrm{pH} 5,0 \ldots \ldots .27$

3.2.12. Meio Completo com solução de $\mathrm{KCl} 0,6 \mathrm{M}$ em tampão fosfato $\mathrm{pH} 5,8$......28

3.2.13. Meio Completo com solução de $\mathrm{KCl} 0,6 \mathrm{M}$ em tampão fosfato $\mathrm{pH} 7,0 \ldots \ldots .28$

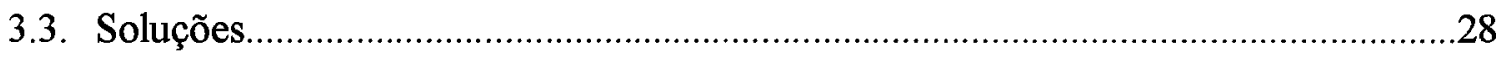

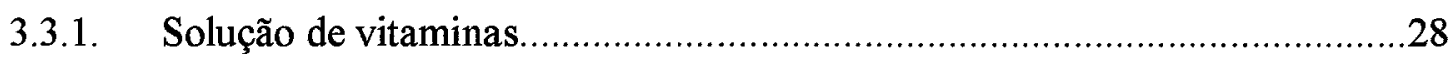

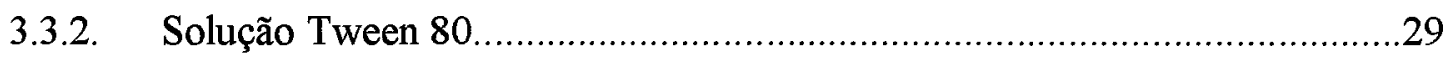

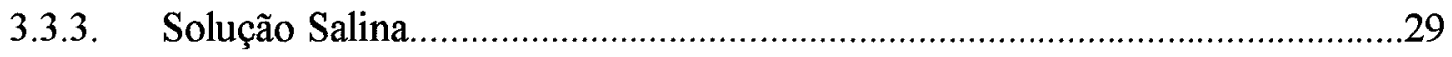

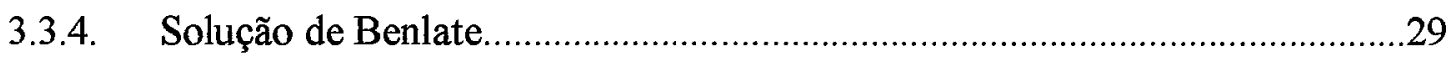

3.3.5. Solução de suplementos adicionais para o meio mínimo................................30

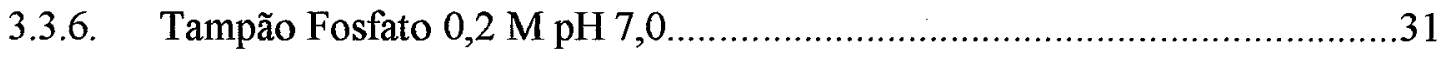

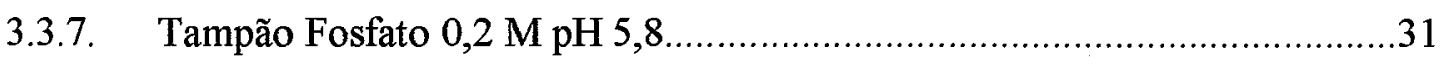

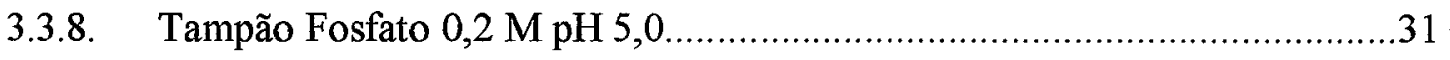

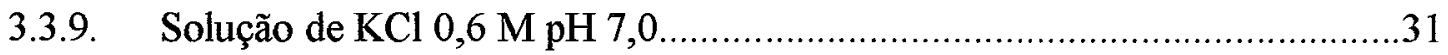

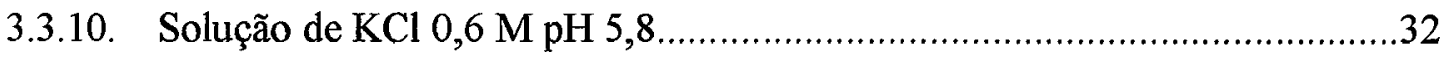

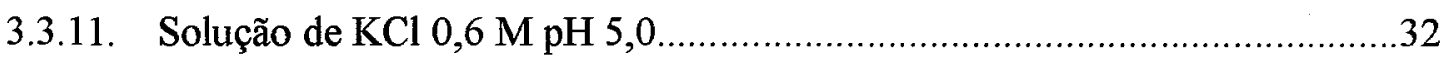

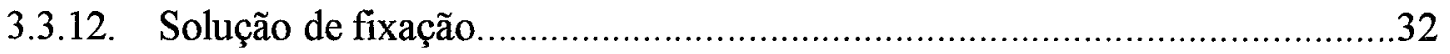

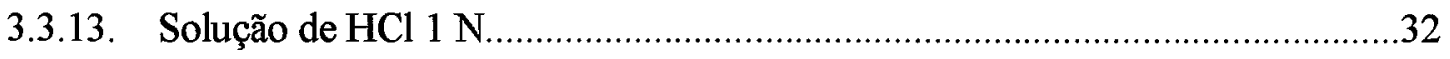

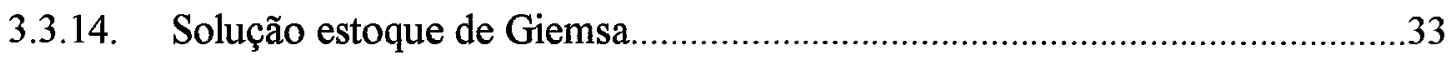

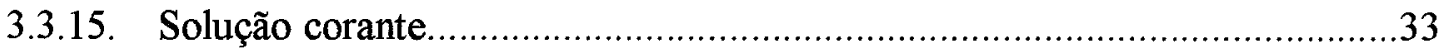

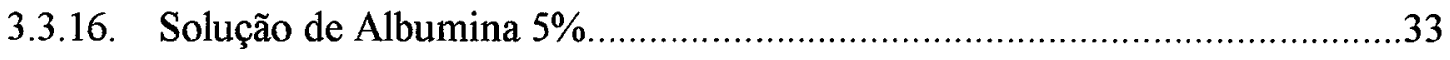

3.3.17. Fixação de fungos para Microscopia Eletrônica de Varredura.......................33 
3.3.18. Tampão Cacodilato de sódio $0,2 \mathrm{M}, \mathrm{HCl} 0,1 \mathrm{M} \mathrm{pH} 7,4 \ldots \ldots \ldots \ldots \ldots \ldots \ldots \ldots \ldots \ldots . . . .34$

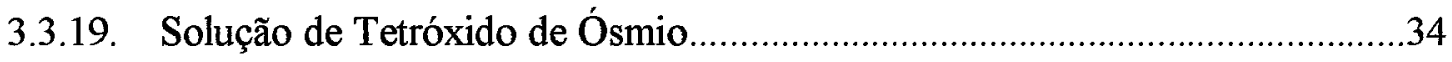

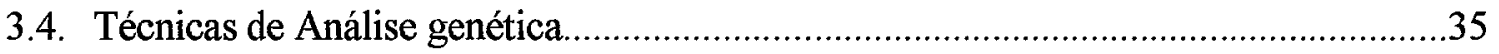

3.4.1. Isolamento de setores deteriorados da linhagem A e Abnc de Aspergillus

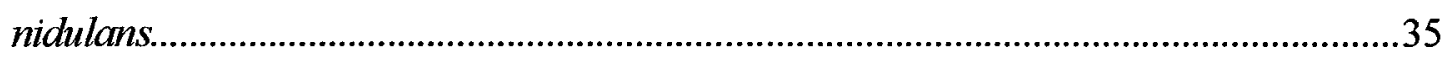

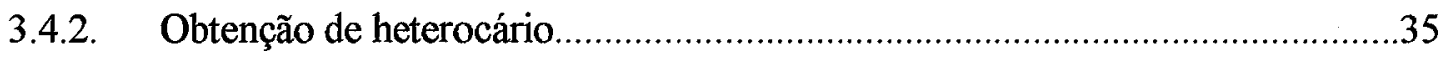

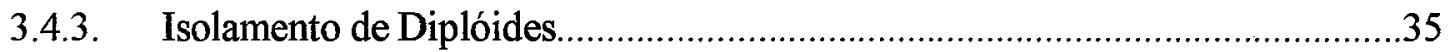

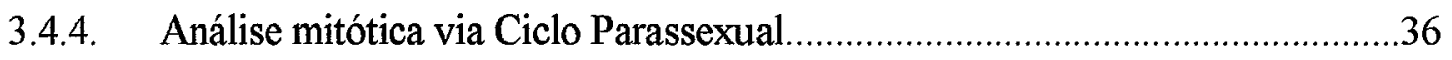

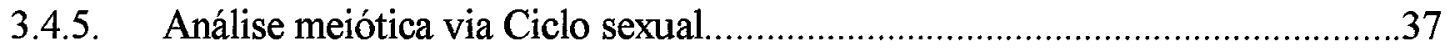

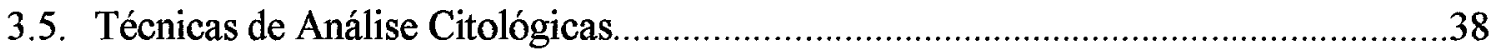

3.5.1. Conidiogênese

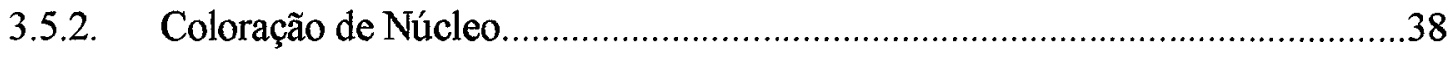

3.5.3. Coloração de Conídio................................................................................

3.5.4. Método de fixação e desidratação de fungos para Microscopia Eletrônica de Varredura (MEV) ................................................................................................. 39

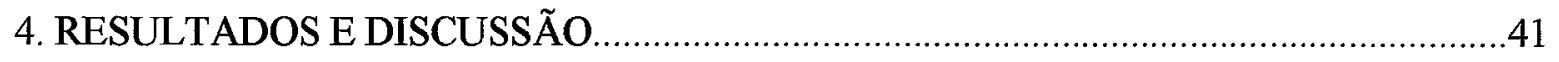

4.1. Obtenção espontânea de setores deteriorados, originários das linhagens A e Abnc de Aspergillus nidulans................................................................................................................... 41

4.2. Características Morfológicas dos Setores Deteriorados................................................45

4.2.1. Teste de auxonografia dos Variantes deteriorados...............................................49

4.2.2. Porcentagem de conídios bi e trinucleados dos Variantes deteriorados da linhagem Abnc.

4.2.3. Resposta da conidiação dos Variantes Deteriorados provenientes da linhagem Abnc, frente a estabilizadores osmóticos e pH ..............................................................51

4.2.4. Medidas do diâmetro de núcleos e conídios dos Variantes Deteriorados

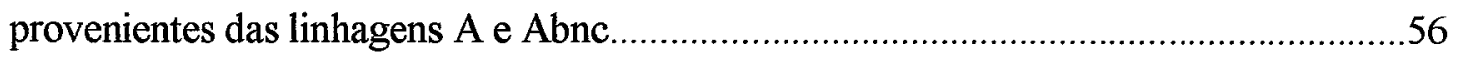

4.3. Conidiogênese

4.3.1. Comparação entre as linhagens MSE, A, MSE/bnc e Abnc....................................60

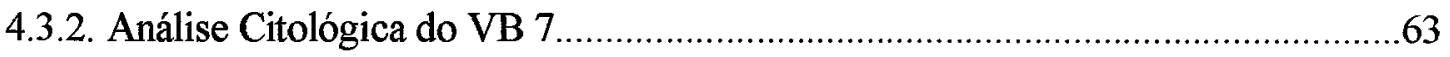




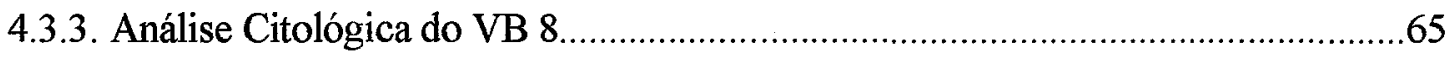

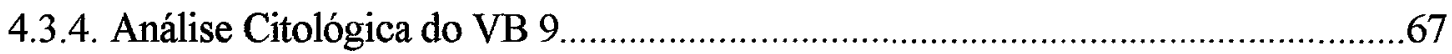

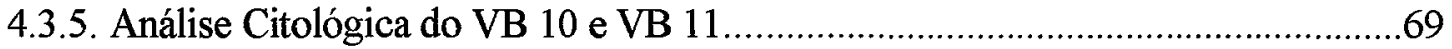

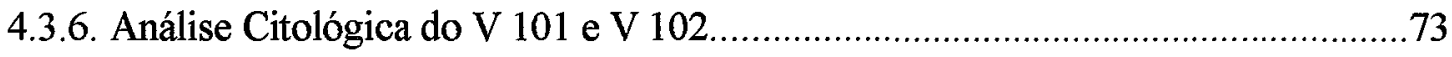

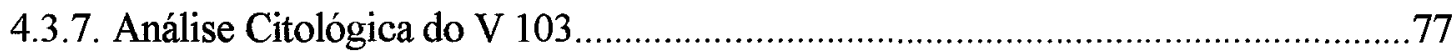

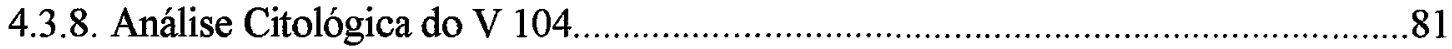

4.3.9 Comparação das Análises Citológicas entre os Variantes Deteriorados

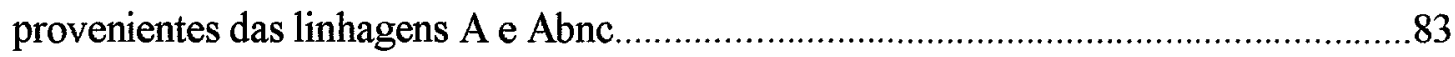

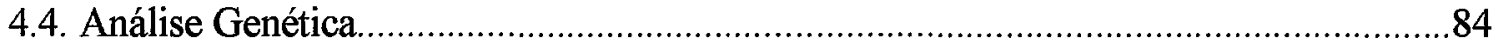

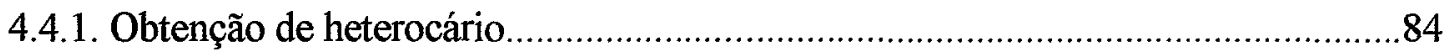

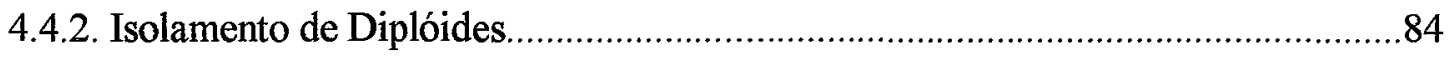

4.4.3 Haploidização

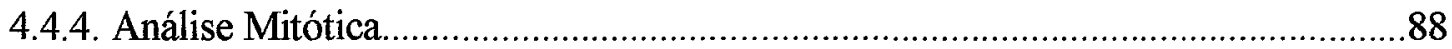

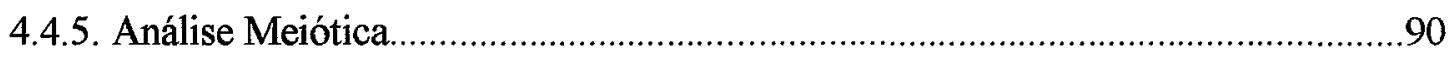

5. CONCLUSÃO.

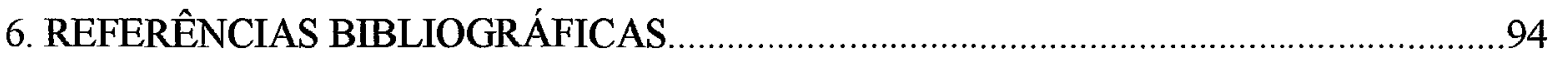

ANEXO A 


\section{LISTA DE FIGURAS}

Páginas

Figura 1 Aspectos Morfológicos dos Variantes Deteriorados originários da linhagem A; a. V 101, b. V 102, c. V 103, d. V $104 \ldots \ldots \ldots \ldots \ldots \ldots \ldots \ldots \ldots \ldots . . . . . . . . . . . . . . . . .46$

Figura 2 Aspecto Morfológico dos Variantes Deteriorados originários da

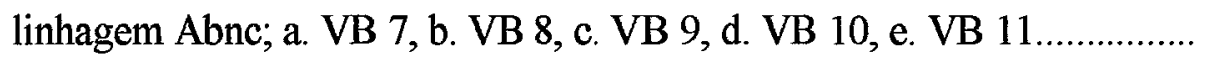

Figura 3 Micrografias de Microscopia Eletrônica de Varredura das linhagens padrões; a MSE aumentos 1000 x, b. MSE/bnc aumento 2000 x; c. linhagem A aumentos $2000 \mathrm{ex}$; $\mathrm{d}$. Abnc aumentos 2000x.

Figura 4 Micrografías de microscopia ótica das linhagens padrões após coloração de Giemsa - HCl. a. linhagem MSE 38 horas; b. linhagem Abnc 38 hora, c.linhagem MSE/bnc 42 horas; d linhagem A 38 hora; d. Aumento $1.000 \mathrm{x}$

Figura 5 Micrografias de microscopia ótica da linhagem VB7 após coloração de Giemsa - $\mathrm{HCl}$; a b. conidióforo com 38 e 54 horas respectivamente. Aumento $1.000 \mathrm{x}$

Figura 6 Micrografias de Microscopia Eletrônica de Varredura da linhagem VB7. A. conidióforo com desorganização temporal e espacial, aumento 3350 vezes; b. conidióforo com formação anormal de esterígmas, aumento 2970 vezes; c. conidióforo normal, aumento 2500 vezes; d, e conidióforos com anormalidades características dos Variantes Deteriorados, aumento 5030 e 4620 vezes respectivamente; f. conidióforo anormal, com formação de novos conidióforos a partir da métula, aumento 4500 vezes. 
Figura 7 Micrografias de microscopia ótica da linhagem VB8 após coloração de Giemsa $-\mathrm{HCl}$, a. conidióforo com desarranjo de esterígmas, 34 horas; b. conidióforo com número reduzido de métulas, 56 horas; c. conidióforo com desenvolvimento alongado de métulas, 42 horas. Aumento de $1.000 \mathrm{x}$

Figura 8 Micrografias de Microscopia Eletrônica de Varredura da linhagem VB8. A, b, c, conidióforo anormal, apresentando menor quantidade e desorganização dos esterígmas, aumento 3630, 4030, 3020 vezes respectivamente.

Figura 9 Micrografias de microscopia ótica da linhagem VB9 após coloração de Giemsa - $\mathrm{HCl}$, a. b conidióforos com elongação de métulas 42 horas. Aumento de 1.000x.......

Figura 10 Micrografias de Microscopia Eletrônica de Varredura da linhagem VB9. a, b conidióforos com desorganização dos esterígmas, aumentos 3580 e 4650 vezes respectivamente; c. conidióforo normal com longas cadeias de conídios, aumento 2970 vezes..

Figura 11 Micrografias de microscopia ótica da linhagem VB 10 após coloração de Giemsa - $\mathrm{HCl}$; a. conidióforo com início do desenvolvimento de métulas, 32 horas; b. conidióforo com métulas alongadas e indiferenciadas, 64 horas, Aumento de $1.000 \mathrm{x}$

Figura 12 Micrografias de Microscopia Eletrônica de Varredura da linhagem VB 10. a, b, c conidióforos com desenvolvimento anormal, aumentos 3190,3870 e 3320 vezes, respectivamente.

Figura 13 Micrografias de microscopia ótica da linhagem VB 11 após coloração de Giemsa - $\mathrm{HCl}$; a. a, b, c. conidióforos com métulas alongadas e indiferenciadas, 34, 64 e 42 horas respectivamente. Aumento de $1.000 \mathrm{x}$

Figura 14 Micrografias de Microscopia Eletrônica de Varredura da linhagem VB 11. a, b, c, conidióforos com desenvolvimento anormal, aumentos 2750 , 3110,3370 vezes, respectivamente. 
Figura 15 Micrografias de microscopia ótica da linhagem V 101 após coloração de Giemsa - $\mathrm{HCl}$, a, b. conidióforos com desorganização de esterígmas, 34 e 38 horas respectivamente. Aumento de $1.000 \mathrm{x}$

Figura 16 Micrografias de microscopia Eletrônica de Varredura da linhagem V 101.a conidióforo normal com células de Hülle, aumento 2630, b. conidióforo com desorganização e esterígmas, aumento 3730 vezes.....

Figura 17 Micrografias de microscopia ótica da linhagem V 102 após coloração de Giemsa - $\mathrm{HCl}$; a, b. conidióforo com número reduzido, desorganização e indiferenciação dos esterígmas, 34 e 64 horas respectivamente. Aumento de $1.000 \mathrm{x}$

Figura 18 Micrografias de microscopia Eletrônica de Varredura da linhagem V 102. a, b, c conidióforos com desenvolvimento anormal dos esterígmas, aumento 3570,2990 e 3340 vezes respectivamente.

Figura 19 Micrografias de microscopia ótica da linhagem V 103 após coloração de Giemsa- $\mathrm{HCl}$; a conidióforos indiferenciados 54 horas. Aumento de $1.000 \mathrm{x}$

Figura 20 Micrografias de Microscopia Eletrônica de Varredura da linhagem V 103. a, b conidióforo com haste ramificada, aumentos 1870 e 3490 respectivamente; c, d conidióforos com desenvolvimento normal, aumentos 3360 e 3300 respectivamente

Figura 21 Micrografias de Microscopia Eletrônica de Varredura da linhagem V 103. a. conidióforo normal, aumentos $1460 ; \mathrm{b}$, células de Hülle envolvendo cleistotécios, aumento 1330; c, d conidióforos com desenvolvimento anormal, com formação de novos conidióforos a partir das métulas, aumentos 3030 e 3420 respectivamente.

Figura 22 Micrografias de microscopia ótica da linhagem V 104 após coloração de Giemsa - HC; a, b. conidióforos com desorganização de esterígmas, 64 e 32 horas respectivamente. Aumento de 1.000 vezes. 
Figura 23 Micrografias de Microscopia Eletrônica de Varredura da linhagem V 104. a, b conidióforo com desenvolvimento anormal dos esterígmas, aumentos 4970 e 2600 respectivamente.

82

\section{LISTA DE TABELAS}

Páginas

Tabela 1 Freqüência total de Setores da linhagem $\mathrm{A}$, obtida neste trabalho após inoculação por ponto central e incubação por 7 dias a $37^{\circ} \mathrm{C}$

Tabela 2 Freqüência total de Setores da linhagem Abnc, obtida neste trabalho após inoculação por ponto central e incubação por 7 dias a $37^{\circ} \mathrm{C}$

Tabela 3 Frequêencia total de Setores da linhagem Abnc reconstruída, obtida neste trabalho após inoculação por ponto central e incubação por 7 dias a $37^{\circ} \mathrm{C}$

Tabela 4 Freqüência de setores, obtida por diferentes autores, a partir de inoculação por ponto da linhagem $\mathrm{A}$, crescida à temperatura de $37^{\circ} \mathrm{C} .$.

Tabela 5 Descrição dos aspectos morfológicos dos variantes deteriorados, provenientes da linhagem A.

Tabela 6 Descrição dos aspectos morfológicos dos variantes deteriorados, proveniente da linhagem Abnc

Tabela 7 Auxonografia dos Variantes deteriorados e das linhagens padrões utilizados neste trabalho.

Tabela 8 Porcentagem de conídios bi e trinucleados dos variantes deteriorados da linhagem Abnc.

Tabela 9 Descrição morfológica das colônias deterioradas frente a variações de pHs e estabilizadores osmótico. 
Tabela 10 Quantificação da esporulação em diferentes pHs e estabilizadores osmóticos

Tabela 11 Média do diâmetro dos conídios uninucleados e binucleados das linhagens MSE, A, bi meth, MSE/bnc, Abnc, V 101, V 102, V 103, V104, VB 7, VB 8, VB 9, VB 10, VB 11

Tabela 12 Média do diâmetro dos núcleos das linhagens MSE, A, bi meth, MSE/bnc, Abnc, V 101, V 102, V 103, V104, VB 7, VB 8, VB 9, VB 10 , VB 11

Tabela 13 Média e desvio padrão do diâmetro dos conídios e núcleos diplóides, obtidos nos cruzamentos, após coloração Giemsa-HCl.............................

Tabela 14 Total de setores obtidos por benlate e purificados dos cruzamentos........

Tabela 15 Total de setores obtidos por radiação U.V. e purificados dos cruzamentos

Tabela 16 Análise Genética Mitótica dos Cruzamentos........................................... 89

Tabela 17 Localização dos determinantes de deterioração nos grupos de ligação... 90

Tabela 18 Teste de $\mathrm{x}^{2}$ para os cruzamentos analisados............................................. 91

Tabela 19 Análise Meiótica dos cruzamentos........................................................ 92 


\title{
CARACTERIZAÇÃo CITOLÓGICA E GENÉTICA DE LINHAGENS DE Aspergillus nidulans PORTADORAS DE DUPLICAÇÃO CROMOSSÔMICA E DO GENE bncA1
}

\author{
Autora: Ágata Cristiane Huppert Giancoli \\ Orientadora: Dra. Aline Aparecida Pizzirani-Kleiner
}

RESUMO

'O estudo da Genética do Desenvolvimento consiste de uma área de grande interesse e complexidade. Entre os organismos estudados, o fungo filamentoso Aspergillus nidulans tem demostrado um excelente organismo para diversos estudos, como genéticos (clássico e moleculares) devido à sua facilidade de obtenção de um grande número de mutantes e à facilidade da manipulação do material genético.

Neste trabalho foram estudadas linhagens de Aspergillus nidulans que possuem duplicação cromossômica e também o gene bncA1. A primeira etapa foi isolar setores deteriorados provenientes das duas linhagens, seguindo a análise da conidiogênese. Os resultados revelam que o gene $b n c A 1$ causa modificações na estrutura do conidióforo causando formações de métulas e fiálides alongadas, multinucleadas e septadas. Os variantes deteriorados que não carregam o gene $b n c \mathrm{~A} 1$ apresentam métulas e fiálides alongadas. No deteriorado V 103, foi detectada uma nova mutação que altera a estrutura do conidióforo sem interferir na formação dos conídios. A segunda parte do trabalho analisou geneticamente os variantes deteriorados portadores do gene $b n c \mathrm{~A} 1$, sendo determinado o grupo de ligação de cada determinante de deterioração assim como a distância de cada marcador genético utilizado. 


\title{
CYTOLOGICAL GENETIC CHARACTERIZATION OF ASPERGILLUS NIDULANS STRAINS CARRIER OF CHROMOSOMAL DUPLICATION AND OF THE BNCA1 GENE
}

\author{
Author: Ágata Cristiane Huppert Giancoli \\ Adviser: Dra. Aline Aparecida Pizzirani-Kleiner
}

SUMMARY

The study of the Development is an area of great interest and complexity. Among the organisms studied, the filamentous fungus Aspegillus nidulans has shown to be an excellent organism for several studies, such as the genetic ones (classical and molecular) due to the facilities to obtain a high number of mutants from it and to manipulate its genetic material.

Aspegillus nidulans strains, carrier of chromosomal duplication and the bncAl gene, were studied in this work. The first stage was to isolate the deteriorated sectors proceeding from two strains and them carry out the conidiumgenesis analysis. The results showed that the $b n c \mathrm{Al}$ gene modifies the conidiophore structure, being responsible for the formation of metulas and elongated, multinucleate and septate phialides. The deteriorated variants that do not carry the $b n c \mathrm{~A} 1$ gene present metulas and elongated phialides. In the deteriorated V 103, a new mutation that alters the conidiophore structure without interfering in the formation of conidia was detected. The second stage of this study analyzed genetically the deteriorated variants carrier of the bncAl gene, determining the connection group of each determinant of deterioration, as well as the distance of each genetic marker used. 


\section{INTRODUÇÃO}

No decorrer da história da genética, diversos estudos têm sido abordados, dos quais merece destaque a elucidação dos mecanismos da Regulação Gênica, em que diversos genes estabelecem relações e controle sobre diferentes tecidos, coordenando o desenvolvimento do organismo como um todo.

Durante a década de 60 , iniciaram-se os estudos sobre o controle do ciclo celular em eucariotos, tendo como organismos padrões Saccharomyces cerevisae e o fungo filamentoso Aspergillus nidulans.

O fungo Aspergillus nidulans é considerado organismo-modelo para estudos genéticos e vem sendo empregado, desde o final dos anos 40, fornecendo importantes contribuições, tanto para a genética básica como aplicada. Até o presente, os estudos genéticos nesse organismo proporcionaram importantes resultados em diversas aéreas como: na obtenção de mutantes, mapeamento genético clássico e molecular, no estudo da instabilidade meiótica e mitótica, transformação, clonagem de genes, no metabolismo celular, no desenvolvimento e diferenciação e na regulação do ciclo celular.

O estudo realizado nesta dissertação caracterizou citologicamente os variantes deteriorados originários da linhagem A de Aspergillus nidulans (Nga e Roper, 1968) a qual é portadora de um segmento do cromossomo I duplicado e translocado para o cromossomo II, gerando instabilidade mitótica que pode ser visualizada pela formação de setores deteriorados, melhorados e heterocarióticos. Também foram caracterizados citológica e geneticamente setores deteriorados provenientes da linhagem Abnc deste fungo, que além de possuir a duplicação cromossômica I $\rightarrow$ I possui a mutação bncA1 que 
produz, além de conídios uninucleados, também conídios binucleados e trinucleados (Pizzirani-Kleiner et al, 1986a, 1986b). A comparação citológica destas duas linhagens demostrou alterações no desenvolvimento temporal e espacial do conidióforo. Estas alterações provavelmente estão relacionadas com os determinantes de deterioração, que se transpõe pelo genoma deste fungo. Além disso a mutação no gene $b n c \mathrm{~A} 1$ causa profundas modificações no conidióforo como fiálides segmentadas e conídios bi e trinucleados. Setores deteriorados originários da linhagem Abnc foram caracterizados genética e citologicamente por Pascon (1994), demostrando que as modificações morfológicas pertencem ao grupo de "modificadores do conidióforo". As análises realizadas nesse trabalho apresentam as mesmas evidências, além de apresentar novos mutantes para o desenvolvimento do conidióforos.

Este trabalho caracterizou-se pela continuidade de uma das linhas de pesquisa do Setor de Genética de Microrganismos da Escola Superior de Agricultura " Luís de Queiroz " ESALQ/USP, sendo realizada análise citológica e genética dos variantes deteriorados originários das linhagens $\mathrm{A}$ e Abnc de $A$. nidulans. 


\section{REVISÃO DA LITERATURA}

\subsection{Introdução}

A revisão da literatura objetivou uma breve abordagem sobre o fungo filamentoso Aspergillus nidulans, ressaltando:

a. sua classificação e características gerais, que o levam a ser um microrganismo modelo para estudos genéticos;

b. ciclo de vida, com ênfase para o ciclo assexual, com o estudo da genética do desenvolvimento, que descreve vários processos morfogenéticos que exigem um refinado processo de regulação gênica.

c. estudo da Instabilidade Genética, destacando as linhagens A e Abnc, que apresentam uma duplicação e translocação $I \rightarrow \Pi$, além do gene bncAl presente na linhagem Abnc, conferindo uma alteração na formação do conidióforo.

\subsection{O fungo Aspergillus nidulans}

O fungo filamentoso Aspergillus nidulans ou Emericella nidulans foi descrito por Eidam (1883, citado por Rocha 1997), sendo sua classificação, segundo Alexopoulo (1962), descrita como pertencente ao: 


\author{
Super Reino Eukaryonta \\ Reino Myceteae (Fungi) \\ Divisão Amastigomycota \\ Sub divisão Ascomycotina \\ Classe Ascomycetes \\ Subclasse Plectomycetidae \\ Ordem Eurotiales \\ Família Eurotiaceae \\ Gênero Aspegillus \\ Espécie nidulans
}

Aspergillus nidulans significa apresório de água benta que faz ninhos. Esta denominação refere-se ao ciclo assexual, onde a formação do conidióforo assemelhase a um apresório. A segunda parte refere-se ao ciclo sexual, onde os cleistotécios (corpos de frutificação) estão cercados por células de Hülle, lembrando o aspecto de um ninho (Clutterbuck e Timberlake, 1992).

O estudo genético de Aspergillus nidulans tiveram êxito com pesquisas realizadas por Guido Pontecorvo, na década de 50 (Pontercorvo, 1952, 1953, 1954), levando esse microrganismo a consagrar-se como modelo biológico para estudos acadêmicos e aplicados.

As vantagens desse fungo para pesquisas consistem na presença de ciclo sexual, assexual e parassexual descritos (Pontecorvo, 1952, Clutterbuck, 1997), ciclo de vida curto, haplóide, homotálico, onde o ciclo sexual se completa sem necessidade de cruzamento entre linhagens sexualmente definidas, além de ser facilmente cultivado em meio de cultura definido e temperatura de $37^{\circ} \mathrm{C}$ (Azevedo e Costa, 1973). 


\subsection{Genética do Desenvolvimento}

O estudo da genética do desenvolvimento é extremamente complexo, envolvendo diversos processos morfogenéticos que exigem refinado processo de regulação. Cada tecido apresenta peculiaridades no seu desenvolvimento espacial e temporal durante as sucessivas mitoses. Além disso, ocorre restrita relação entre os ciclos de multiplicação celular e os processos de diferenciação celular, nos quais uma quantidade enorme de genes interage.

Devido a esses fatores, o fungo filamentoso Aspergillus nidulans tem-se revelado um organismo modelo para o estudo da Genética do Desenvolvimento, devido a características como: seu ciclo de vida rápido, haplóidia, presença de poucos tipos celulares distintos, mas com função bem diferenciada, além de uma morfogênese bem definida, possibilidade de sincronismo na conidiogênese, tornando viável o isolamento e a análise de compostos bioquímicos específicos. (Miller, 1990; Morpurgo, 1994).

O fungo Aspergillus nidulans apresenta seu ciclo de vida dividido em três fases:

a. Ciclo vegetativo;

b. Ciclo Assexual ou conidiogênese;

c. Ciclo Sexual ou Ascosporogênese.

Entre os ciclos de vida, ocorre uma estreita relação. Em condições normais, primeiramente ocorre o desenvolvimento vegetativo e após tem-se o início da conidiogênese, que acarreta na diminuição do desenvolvimento vegetativo para o amadurecimento do conidióforo (Adams et al, 1990). Estudos genéticos e bioquímicos demostraram que os ciclos de vida são induzidos por substâncias como o fator psi (precocious sexual inducer), (Champe, et al, 1987; Champe \& El-Zayat, 1989). O fator psi é subdividido em três partes: psiA, psiB e psiC, os quais fazem parte dos metabólicos de ácidos graxos (Mazur et al, 1990). 


\subsubsection{Ciclo Vegetativo.}

No desenvolvimento do ciclo vegetativo, que pode ocorrer através de fragmentos de hifas, esporos sexuais e assexuais, ocorre inicialmente o aumento do volume do esporo, seguindo de sucessivas divisões mitóticas, originando o tubo germinativo (Harris, 1998).

O tubo germinativo apresenta desenvolvimento apical, com divisões mitóticas dos núcleos mais próximos do ápice, ocorrendo ainda a formação periódica de septos. Os septos delimitam células com 8 a 16 núcleos. Os septos proporcionam a passagem de organelas e núcleos entre as células (Morris, 1976). Após o desenvolvimento do primeiro tubo germinativo, um segundo tubo é emitido em orientação oposta ao primeiro Deste modo, em meio de cultura sólido, as hifas ramificam-se e crescem de forma subapical, formando uma colônia com crescimento radial (Pontecorvo et al, 1953).

\subsubsection{Ciclo Sexual ou Ascosporogênese}

O ciclo sexual em Aspergillus nidulans caracteriza-se por apresentar organelas especializadas denominadas de corpo de frutificação ou cleistotécios. Em condições normais de crescimento, em meio sólido, os cleistotécios começam a desenvolver-se após 5 - 10 dias, depois da inoculação. Os cleistotécios são corpos esféricos com o diâmetro entre 100 a $200 \mu \mathrm{m}$, que possuem diversas células adjacentes, denominadas de células de Hülle (Pontecovo, 1953). Um dos eventos precoces, conhecido na morfogênese do ciclo sexual, é o desenvolvimento dos primórdios dos cleistotécios, sendo esta etapa caracterizada pela produção da enzima lacase II , a qual em conjunto com a lacase I, são responsáveis pela síntese de pigmento verde dos conídios (Clutterbuck, 1972). A lacase I é encontrada unicamente nos esterígmas secundários ou fiálides dos conidióforos, enquanto a lacase II é expressa unicamente nos primórdios dos cleistotécios e nas células de Hülle (Herman et al, 1983) 
As células de Hülle caracterizam-se por serem grandes, globosas e produtoras de lacase $\Pi$, estando intimamente relacionadas com o desenvolvimento dos cleistotécios. Na fase de primórdios, essas células já estão associadas aos cleistotécios nascentes. As células de Hülle possuem aproximadamente $12 \mu \mathrm{m}$ de diâmetro e sua função específica encontra-se obscuras mas supõe-se que seja de suprir a hifa primordial de lacase II (Hermam et al, 1983).

O início do desenvolvimento dos cleistotécios ocorre com a diferenciação da extremidade de uma hifa (hifa ascógena), que encurva como um gancho (crozier). Os dois núcleos presentes neste primórdio de asco sofrem mitose, seguida da fusão dos dois núcleos resultantes. $\mathrm{O}$ núcleo diplóide originado sofre divisões meióticas, originando quatro células, que irão sofrer sincronicamente mitose, originando oito células. Uma nova mitose ocorre nessas oito células formadas, mas sem a ocorrência de citocinese, levando a formação de oito ascósporos binucleados em cada asco. Este processo repete-se centenas de vezes, sempre com os mesmos dois núcleos iniciais, presentes na hifa ascógena. Todos os ascos formados são originários de uma mesma célula diplóide inicial, mas cada célula é resultante de uma meióse (Pontecorvo, 1953; Kirk \& Morris, 1991).

\subsubsection{Ciclo Assexual ou Conidiogênese.}

O crescimento vegetativo tem início com a germinação do esporo, podendo este ser um conídio ou um ascósporo. A germinação do esporo direciona a formação de hifas tubulares que crescem de forma polar, por extensão apical, e ramificamse formando uma rede inter-conectada de células, denominadas de micélio. Após 16 horas, aproximadamente, da germinação do esporo, ocorre a primeira evidência fenotípica de especialização da hifa a qual é observada dentro da colônia (Lee \& Adams, 1994). A hifa aérea ramificada diferencia-se em um conidióforo, estrutura reprodutora do ciclo assexual de Aspegillus nidulans (Adams et al, 1998). O processo de desenvolvimento e de diferenciação do conidióforo, até a formação dos conídios, constitui a Conidiogênese. 
A ultraestrutura do desenvolvimento e diferenciação do conidióforo de $A$. nidulons, analisada por Mims et al. (1988) e revisada por Timberlake \& Clutterbuck (1994), pode ser dividida, considerando-se cinco estágios de desenvolvimento:

1. o primeiro estágio do desenvolvimento do conidióforo envolve a transformação de uma célula de hifa em uma célula pé, estrutura que sustenta e desenvolve o conidióforo. A célula pé pode ser distinguida das outras células por possuir duas camadas de parede celular (Oliver, 1972). A camada exterior ou parede primária é constituída pela parede da própria hifa basal e a camada mais interna ou parede secundária limita o início e o final da célula pé (Oliver, 1972; Yager, 1992). Em relação ao núcleo, a célula pé pode ser uninucleada, ou ocorrer mais de um núcleo, como foi demostrado em heterocários (Clutterbuck \& Spathas, 1984; Pizzirani-Kleiner \& Azevedo 1986a, 1986b). A partir da célula pé, há o desenvolvimento da haste do conidióforo que é multinucleado e asseptado. A região apical da haste é rica em vesículas que possuem substâncias precursoras e polimerizadoras da parede celular, estas vesículas fundem-se a membrana plasmática promovendo o alongamento da haste (Gooday, 1983);

2. a partir da célula pé forma-se a haste do conidióforo, que sofre um alargamento gradual do seu ápice, formando uma vesícula, que também possui dupla camada de parede celular. Durante a formação da vesícula do conidióforo, ocorre um acúmulo de vesículas intracelulares, que possuem em seu interior substâncias precursoras e polimerizadoras da parede celular no ápice da vesícula (Oliver, 1972). A vesícula do conidióforo possui vários núcleos que sofrem divisão mitótica;

3. com a vesícula formada, tem início o desenvolvimento das métulas (Oliver, 1972), as quais surgem como protuberâncias na superfície interna da parede da vesícula, isto provavelmente pela dissolução da parede secundária (Oliver, 1972). Durante o desenvolvimento das métulas, são observados agregados nas protuberâncias das vesículas, de onde emergem as métulas. As vesículas citoplasmáticas persistem no ápice das métulas até seu completo desenvolvimento. A sua função, provavelmente está relacionada com a formação da parede celular do fungo. Oliver (1972) também observou um grande número de vesículas citoplasmáticas, que estão aderidas na parede celular das métulas, provavelmente responsáveis pela síntese de novas paredes celulares. Em relação 
ao núcleo, ocorre a migração nuclear da região apical da vesícula para a métula, tornando-a uninucleada, e posteriormente sofre divisão mitótica. A delimitação entre vesícula e métula ocorre pela deposição de um septo descontínuo, com poro central que permite a comunicação citoplasmática entre os dois compartimentos;

4. no ápice das métulas ocorre o brotamento das fiálides. $\mathrm{O}$ núcleo que está na métula sofre divisão mitótica, originando um núcleo filho, que migra para a fiálide, sendo que outro núcleo permanece na métula. A comunicação citoplasmática entre a métula e fiálide ocorre pela formação de septos descontínuos com poro central;

5. ao completar o desenvolvimento das fiálides tem início a formação dos conídios primários, os quais são originários do ápice das fiálides. Durante este processo ocorre uma divisão mitótica do núcleo presente na fiálide. $\mathrm{O}$ núcleo fillho migra para o conídio em formação (Sewall et al., 1990; Bergen \& Morris, 1983; Pascon, 1994). A formação da parede celular dos conídios tem início com o prolongamento das paredes primárias e secundárias das fiálides. No decorrer da maturação dos conídios ocorre, deposição de novas membranas, tornando-os impermeáveis e garantindo a sua dormência.

\subsection{Aquisição da competência}

O fungo Aspergillus nidulans pode manter-se indefinidamente no estágio vegetativo do seu ciclo de vida. A esporulação assexual e sexual ocorrem unicamente na exposição de superficies aeradas. Aproveitando-se desta condição, é possível sincronizar e induzir o desenvolvimento da conidiogênese (Axelrod, 1972; Law \& Timberlake, 1980).

O estabelecimento da competência é dependente de condições particulares empregadas para cada meio de cultura, mas geralmente a competência é adquirida após 20 horas de crescimento a $37^{\circ}$ C. Antes deste período, as colônias são incapazes de entrar na conidiogênese mesmo que ocorra a indução por aeração. Miller (1990) e Axelrod et al (1973) observaram que, antes de 20 horas de crescimento, as células não respondem à indução, e após este período a resposta leva horas para se realizar. As células capazes de responder imediatamente à indução são consideradas como competentes. 
O processo de controle para aquisição da competência obedece a um controle endógeno, isto porque fatores como densidade de células e fornecimento contínuo de meio de cultura não surtem efeito sobre o início da conidiogênese (Pastushok \& Axelrod, 1976).

A conidiogênese em linhagens selvagens de $A$. nidulans necessitam de exposição à luz (Käfer, 1960; Timberlake \& Clutterbuck, 1994), sendo essa dependência determinada pelo locus velvet ( $v e \mathrm{~A})$. As linhagens utilizadas em laboratório não necessitam de luz para a conidiogênese, decorrente de uma mutação ve $\mathrm{A}_{1}$ no locus veA (Mooney et al, 1990).

Clutterbuck (1969) e Martinelli \& Clutterbuck (1971) foram os primeiros a estudarem e descreverem mutantes para o desenvolvimento em Aspergillus nidulans. A análise de mutantes para os diferentes passos da conidiogênese tem permitido esclarecer o desenvolvimento e diferenciação em $A$. nidulans. Esses mutantes se enquadram em duas classes de acordo com Timberlake (1990):

a. Classe I, mutantes relacionados com a aquisição de competência, isto é, genes que controlam a transição do crescimento indiferenciado da hifas para a diferenciação do conidióforo.

b. Classe II, mutantes que afetam a formação do conidióforo e conídio.

Essa última classe é subdividida em quatro grupos conforme, Clutterbuck (1969):

b1 - mutantes para alterações conidiais (yA; wA; fwA; wetA);

b2 - mutantes com alteração no conidióforo, mas que não afetam a formação dos conídios (stuA; medA);

b3 - mutantes que bloqueiam a formação dos conídios (brlA; abaA);

b4 - mutantes que afetam a pigmentação dos conídios (ivoA; ivoB).

Em outra classificação, Miller et al. (1992) divide os mutantes em dois grupos: "bristle" e "stunted", sendo que no primeiro estão incluídos três genes (brlAbristle $\rightarrow$ abaA-abacus $\rightarrow$ wetA-wet-white) que atuam em cadeia epistática e sem os quais não há formação do conidióforo e dos conídios e no segundo grupo, dois genes estão envolvidos stuA $\rightarrow$ medA. 
Diversos estudos morfológicos, bioquímicos e moleculares foram realizados sobre estes tipos de mutantes, como exemplo estudos realizados por Yelton et al. (1985); Johnstone et al. (1985); Butnick (1984); Boylan et al. (1987); Adams et al. (1988); Mirabito et al. (1987); Sewal et al. (1990); Miller et al. (1992); Prade \& Timberlake (1993); Han et al. (1993); Chang et al. (1992); Timberlake \& Clutterbuck (1994).

\subsection{Controle Genético da Esporulação}

A ativação e controle da diferenciação celular durante o ciclo de vida de Aspergillus nidulans são estabelecidos por centenas de genes. Apesar da grande quantidade de genes envolvidos neste processo alguns já possuem sua função determinada. Timberlake (1990) relatou a existência de aproximadamente 1200 mRNA diferentes, que variam em sua concentração específica durante a conidiogênese. Contrastando esse dados, Martinelli e Clutterbuck (1971), utilizando análise mutacional, estimaram que entre 45 - 100 genes estão presentes durante a diferenciação assexual. Esta discrepância pode ser explicada pelo fato de que alguns genes detectados apresentam expressão morfológica, podendo ser detectados por uma simples análise visual, enquanto outros genes para o desenvolvimento da conidiogênese não apresentam alterações morfológicas, como ocorre no caso de deleções em regiões de $38 \mathrm{~Kb}$ de $A$. nidulans, contendo genes específicos para esporulação, as quais causam modificações no desenvolvimento que não são detectáveis visualmente.

Martinelli e Clutterbuck (1971) limitaram suas análises em mutantes que sofrem alteração no seu crescimento vegetativo. Estes autores verificaram presença de mRNA em altos níveis durante a esporulação que podem estar presentes em pequenos níveis em células vegetativas, sendo requeridos também, para alguns aspectos do crescimento e metabolismo vegetativo. De fato, muitos cDNA isolados durante a conidiogênese possuem genes que podem estar envolvidos no metabolismo do carbono ou ainda genes que atuam em outros processos celulares, o que Martinelli e Clutterbuck podem ter excluído de suas análises. 
Indiferente ao número atual de loci identificados na genética do desenvolvimento da conidiogênese, é certo que muitos genes são especificamente requeridos para a esporulação e, em alguns casos, é necessária a transcrição destes para o controle específico do desenvolvimento do conidióforo.

Através de estudos de genética molecular, demostrou-se que a conidiogênese possui dois genes principais descritos e identificados o $b r l \mathrm{~A}$ e $a b a \mathrm{~A}$, os quais são requeridos especificamente para o desenvolvimento normal dos conídios, não afetando o início do desenvolvimento do ciclo assexual (Clutterbuck, 1969). Juntamente com um terceiro gene o wetA, brlA e $a b a \mathrm{~A}$, podem ser considerados como os genes principais, que atuam no caminho central da regulação do desenvolvimento da conidiogênese Estes três genes, juntamente com outros genes, são responsáveis pelo controle da expressão gênica da conidiação, determinando a ordem da ativação durante o desenvolvimento e maturação do esporo (Boylan et al, 1987).

Os genes wetA, $y \mathrm{~A}, w \mathrm{~A}$ e $d r k$ são caracterizados como modificadores do conidióforo, estando também relacionados com a pigmentação dos conídios.

Os mutantes dark ( $d r k$ ) possuem a coloração mais escura que a linhagem padrão de $A$. nidulans, além de possuírem uma camada mais externa da parede celular que envolve não apenas os conídios, mas forma um saco que engloba toda a cadeia de conídios (Oliver, 1972).

O locus $w \mathrm{~A}$ pode ser considerado o primeiro de uma cadeia epistática, responsável pela coloração dos conídios. $\mathrm{O}$ locus $w \mathrm{~A}$ codifica uma enzima que converte um precursor em um produto secundário, que servirá de substrato para a enzima $\rho$ - difeno oxidase (lacase) que é codificada pelo locus yA

O locus $y$ A foi identificado por Pontecorvo et al (1953) por meio de mutações. Este gene confere a característica de conídios amarelos ao invés de conídios verdes. $\mathrm{O}$ gene $y \mathrm{~A}$ codifica a enzima $\rho$ - difeno oxidase (lacase), rica em cobre, que possui a função de converter o pigmento amarelo intermediário em pigmento verde, cuja função é proteger o conídio da radiação ultravioleta. Mutantes $w \mathrm{~A}^{-}$possuem a coloração do conídio branca. $\mathrm{O}$ locus $w \mathrm{~A}$ é epistático para $y \mathrm{~A}$, indicando que os genes $w \mathrm{~A}$ e $y \mathrm{~A}$ codificam enzimas envolvidas na síntese do mesmo pigmento, responsável pela coloração do conídio 
(Clutterbuk, 1972). O gene $y \mathrm{~A}$ foi isolado por O' Hara e Timberlake (1989), apresentando um fragmento de $2,2 \mathrm{~kb}$, que complementa a mutação $y \mathrm{~A}_{1}$. Este gene está localizado no grupo de ligação I entre os marcadores auxotróficos paba $\mathrm{A}_{1}$ e bi $\mathrm{A}_{1}$.

$\mathrm{O}$ gene wet - white (wet) apresenta conídios brancos, aparentemente normais, mas que apresentam autólise poucos dias depois de maduros (Rocha, 1997). O gene wetA codifica um polipeptídio rico em serina (14\%), treonina $(17 \%)$ e prolina $(10 \%)$ (Marshall et al, 1991). Este polipeptídeo não se encontra presente em células indiferenciadas do micélio, mas aparece acumulado durante a maturação dos conídios. A análise da seqüência do gene wetA não fornece uma clara indicação da função deste, mas especula-se que este gene é um controlador da expressão de gene esporo - específico (Marshall et al, 1991). Esta hipótese baseia-se em estudos de diversos mutantes wetA, os quais acumulam uma grande quantidade de mRNA específico durante a conidiação (Boylan et al, 1987).

Os mutantes Bristle (brl) e Abacus ( $a b a)$ são classificados como mutantes aconidiais. Os mutantes $b r l$ foram incluídos neste grupo devido a algumas linhagens desenvolverem apenas a haste do conidióforo, que se alongam até 2 - $3 \mathrm{~mm}$ e não desenvolvem vesículas nem qualquer outra estrutura subsequente na diferenciação do conidióforo. Entretanto, muitos outros mutantes brandos para o gene brl desenvolvem conidióforos aberrantes, com cadeias de métulas que se diferenciam e originam novos conidióforos. Os conídios podem ser formados em maior ou menor quantidade, de acordo com o nível de comprometimento dos conidióforos (Rocha, 1997; Catro - Prado \& Rocha, 1998). Clutterbuck (1969) observou que entre 36 mutantes brl, muitos apresentavam fenótipos intermediários entre "bristle" grave, onde ocorre apenas a formação do conidióforo, e o fenótipo normal sugerindo a formação de um gradiente de fenótipos bristle a fenótipo normal. Este gradiente entre fenótipos foi comprovado por estudos de mutantes bristle sensíveis a temperatura e osmolaridade (Clutterbuck e Timberlake, 1992).

$\mathrm{O}$ gene bristle de linhagens selvagens de $A$. nidulans foi isolado por complementação de mutantes (Boylan et al, 1987; Johnstone et al, 1985). Os resultados obtidos mostram duas unidades de transcrição denominadas de $b r l A \alpha$ e $b r l A \beta$. A unidade brlA $\alpha$ possui $2,1 \mathrm{~kb}$ e a unidade brlA $\beta$ apresenta $2,5 \mathrm{~kb}$.Estas unidades ao serem transcritas 
em polipeptídio apresentam uma diferença de 23 aminoácidos a mais para a unidade $b r l A \beta$. Durante o início da transcrição, ocorre sobreposição na região estrutural, isto é as duas subunidades estariam sobrepostas, sendo que o transcrito $b r l A \beta$ inicia a transcrição a quase $1 \mathrm{~kb}$ à frente do transcrito $b r l \mathrm{~A} \alpha$. Mutações expressando cada um dos transcritos sozinhos levam a um desenvolvimento anormal do conidióforo (Prade e Timberlake, 1993). De qualquer modo, múltiplas cópias de qualquer $b r l A \alpha$ ou $b r l A \beta$ podem compensar a falta do outro. Estes resultados são consistentes com a hipótese de que a transcrição das unidades brlA $\alpha$ e $b r l A \beta$, são individualmente essenciais para o desenvolvimento normal do conidióforo, mas cada produto das unidades possuem funções redundantes. Han et al, (1993) demostrou que brlA $\alpha$ e brlA $\beta$ são controlados por diferentes mecanismos moleculares, sugerindo que a unidade de transcrição do locus $b r l A \alpha$ é expressa durante todo o desenvolvimento.

O gene brlA, codifica a proteína BRL, que possui 432 aminoácidos, sendo rica em prolina (10\%), além de possuir duas regiões apresentando a conformação denominada de "zinc fingers", que consistem em estruturas protéicas características de ligação ao DNA (Miller et al, 1985; Johnston et al, 1985; Adams et al, 1998). Supõe-se que esta proteína tenha uma função de regulação, uma vez que esta liga-se ao DNA, sendo sua presença necessária para desencadear o desenvolvimento do conidióforo (Adams et al, 1998)

O mutante para o gene abacus ( $a b a$ ) apresenta conidióforos com estruturas que lembram um abaco, em lugar de fiálides e conídios. A análise ultraestrutural destes mutantes indica que estas estruturas são intermediárias entre métulas e fiálides (Sewall et al, 1990; Rocha, 1997).

A proteína codificada pelo gene $a b a \mathrm{~A}$, possui uma região estrutural denominada de "leucina zipper", a qual é semelhante a proteína brlA, sendo que abaA é requerido para a ativação transcricional de numerosos genes específicos para a esporulação.

$\mathrm{A}$ ativação de $a b a \mathrm{~A}$ com um promotor forte, $\operatorname{alc}_{(\mathbf{p})}(\operatorname{alc\mathrm {Ap}}:: a b a \mathrm{~A})$, em hifas vegetativas, resulta na interrupção do crescimento acentuado da vacualização celular, mas não na diferenciação dos conídios (Adams et al, 1990; Mirabito et al, 1987). A indução 
do gene $a b a \mathrm{~A}$ também leva à ativação de alguns genes específicos para o desenvolvimento, sendo alguns conhecidos como wetA e brlA e outros ainda desconhecidos. Os genes wetA e brlA são induzidos reciprocamente, mas a expressão de brlA deve ocorrer antes da expressão de abaA para o desenvolvimento reprodutivo do conidióforo. Para a formação das fiálides apenas a expressão de brlA é necessária, mas para as fiálides tornarem-se funcionais e produzirem conídios, é necessária a expressão do gene abaA (Clutterbuck, 1977). A expressão induzida de brlA nas hifas indiferenciadas, ativa a transcrição de $a b a \mathrm{~A}$ com o desenvolvimento de fiálides funcionais. A ativação induzida de gene $a b a \mathrm{~A}$ não leva à formação imediata de fiálides e conídios, mas ativa a transcrição do gene $b r l A$, causando alterações morfológicas no conidióforo. Devido a esse comportamento, a ativação do gene $a b a$ deve ocorrer ordenadamente, para que a diferenciação de fiálides funcionais ocorra normalmente. Desse modo, as mutações brlA são epistáticas para as mutações $a b a \mathrm{~A}$ e wetA, e a mutação abaA é epistática para a mutação wet $\mathrm{A}$, em ambos níveis moleculares $\mathrm{e}$ morfológicos (Sewal et. al., 1990).

Os genes student (stu) e medusa (med), são considerados como modificadores do conidióforo. Esses genes são requeridos para uma série de divisões celulares que estabelecem a organização espacial e temporal do conidióforo. Mutações em qualquer um destes dois genes proporcionam o desarranjo da organização espacial e temporal do conidióforo, mas ambos genes produzem conídios viáveis (Clutterbuck, 1969).

Mutações no gene siuA resultam na produção de conidióforos curtos com a falta de métulas e fiálides, e a produção de conídios ocorre diretamente da vesícula do conidióforo (Rocha, 1997).

stuA é um codificador de um fator de transcrição que possui similaridade com fatores de transcrição de outros fungos (Gimeno et al, 1992), isto inclui Swi4, Mpb1 e Phd1 de $S$. cerevisae e Ras1 e Cdc10 para Schizosaccharomyces pombe. StuA possui maior similaridade com o gene Phd1, onde sua expressão leva à indução de pseudohifas, que podem ser completas morfologicamente e talvez funcionalmente análogas ao conidióforos (Gimeno et al, 1992). Durante o desenvolvimento da pseudohifa nos mutantes para o gene Phd 1, ocorre elongação polar de células mãe, originando células filhas que irão produzir os filamentos. Este caminho do desenvolvimento de pseudohifas é semelhante a morfogênese 
do conidióforo, onde a elongação de métulas e fiálides consiste do resultado da germinação polar das vesículas. Estas divisões polares são necessárias para mutantes stuA. Entretanto, a expressão do gene stuA permite o gene $b r l \mathrm{~A}$ orientar a diferenciação terminal e promover o crescimento das pseudohifas (Busby et al, 1996).

Semelhante ao gene bristle, o gene stuA também possui dois transcritos stuA $\alpha$ e stuA $\beta$, que são transcritos em diferentes sítios de transcrição (Miller et al, 1992; Dutton et al, 1997).

O gene medusa (medA) leva à formação de conidióforos de tamanhos normais, mas as métulas não sofrem diferenciação, originando novos conidióforos completos (Rocha, 1997). Semelhante aos genes stuA e brlA, o gene medA também possui dois transcritos (Adams et al, 1998).

Enquanto stuA é importante para a distribuição espacial do transcrito do gene $\operatorname{brl\mathrm {A}}$, o gene medA aparentemente é requerido para a correta expressão temporal do mesmo (Busby et al, 1996). Ambos transcritos brlA $\alpha$ e $b r l A \beta$ são detectados mais cedo em mutantes stuA do que em linhagens selvagens, além disso o transcrito $b r l A \alpha$ continua a ser produzido, mesmo com o desenvolvimento completo do conidióforo, o que não ocorre com linhagens selvagens (Adams et al, 1998).

$\mathrm{O}$ gene $a b a \mathrm{~A}$ é essencial para o desenvolvimento das fiálides. Linhagens que apresentam a mutação medA possuem a expressão anormal do gene $a b a \mathrm{~A}$, sendo esta reduzida ou ausente (Busby et al, 1996). O fenótipo mutante de medA é supresso por uma cópia extra do gene $b r l \mathrm{~A}$, mas esta supressão é sensível à variação da temperatura (Busby et al, 1996). Esses resultados indicam uma interação física entre medA e blrA, demostrando que isso ocorre através de medA que atua como estabilizador do complexo transcricional, que está presente o gene bristle.

Entre os mutantes para pigmentação do conidióforo, destacamos o mutante ivory (ivoA), que possui independência da coloração dos conídios, apresentando conidióforos sem pigmentação marrom característica. Este gene demostrou interessante relação com o gene $b r l \mathrm{~A}$, uma vez que mutantes severos para $b r l \mathrm{~A}$ também eram mutantes ivoA, embora esses dois genes não fossem ligados (Clutterbuck, 1969 e 1990; Rocha, 
1997). O gene ivoA foi mapeado no cromossomo III e o gene ivoB está presente no cromossomo VIII (Clutterbuck, 1969, 1977 e 1997).

Os genes pertencentes à classe $I$, isto é, mutantes relacionados com a aquisição da competência, são inúmeros, sendo destacados os genes velvet (veA), que em linhagens selvagens são responsáveis pela dependência da luz como estímulo inicial para a conidiogênese (Mooney \& Yager, 1990). Esse gene é pleiotrópico, sendo que o mutante veA1 não produz hifas aéreas típicas, como da linhagem selvagem (Kafer, 1960 e 1961), além de ser incapaz de produzir cleistotécios a $42^{\circ} \mathrm{C}$ (Champe et al., 1981).

Outro mutante de interesse é o Fluffy $(f l u)$, que possui micélio aéreo indiferenciado e envasivo, perdendo a inibição por contato e crescendo sobre outras colônias (Ball \& Azevedo, 1964; Tamame, et al., 1983). O tratamento de hifa com 5azacitidina acarreta a expressão do fenótipo fluffy. Essa resposta é decorrente da mutação no gene $f l u$ F que foi mapeado no cromossomo VIII, tendo estreita ligação com o centrômero (Tamame, et. al., 1983 e1988). Considerando que 5-AC é um inibidor de metiltransferases de DNA, foi proposto que a droga causa alterações no padrão de metilação deste gene, levando o fungo a tornar-se incapaz de responder normalmente ao estímulo para a diferenciação.

\subsection{Relação entre o Ciclo Assexual e Sexual}

A ascosporogênese ocorre após o término da conidiogênese, envolvendo a formação de estruturas macroscópicas denominadas de cleistotécios. A formação dos cleistotécios e ascósporos é um processo claramente distinto da formação de conidióforos e conídios, mas esses dois eventos de grande importância para o ciclo de vida de $A$. nidulans possuem alguns aspectos em comum.

Muitos mutantes, originalmente identificados como causadores de anomalias durante o desenvolvimento do conidióforo, também podem causar anomalias no ciclo sexual (Yager, 1992). Mutantes para o gene stuA são incapazes de originar 
cleistotécios e células de Hülle. Os mutantes medA são incapazes de produzir cleistotécios, mas ocorre a formação de células de Hülle (Clutterbuck, 1969).

O gene veA também é importante para a determinação da esporulação sexual. Mutantes ve $\mathrm{A}_{1}$ possuem geralmente produção reduzida de cleistotécios, enquanto que a conidiação é mais eficiente do que as linhagens normais ve $\mathrm{A}^{+}$. Além disso, incubando $v e \mathrm{~A}^{+}$em ausência de luz, ocorre a redução da conidiação, mas a formação inicial de cleistotécios continua, sendo inclusive mais prolífera, quando comparada com as mesmas linhagens que foram crescidas em luz (Adams et al, 1998)

Han et al (1994 e 1990, citado por Adams, 1998), descreveram um extenso grupo de mutantes que bloqueiam o desenvolvimento do cleistotécio, sendo definidas três classes de mutantes. A primeira classe inclui 20 mutantes denominados de NSD (Never in Sexual Development), visto que essas linhagens de mutantes possuem uma queda na produção de células de Hülle e / ou cleistotécios. A segunda classe inclui mais de 100 mutantes denominados de BSD (Blocked in Sexual Development), uma vez que essas linhagens de mutantes possuem o desenvolvimento inicial dos cleistotécios, mas ocorre bloqueio durante a formação dos ascósporos. A terceira classe inclui mais de 100 mutantes denominados de ASD (Abnormal Sexual Developmental), isto devido ao fato que esses mutantes produzem cleistotécios pequenos ou ocorre uma demora maior desses mutantes para o desenvolvimento dos cleistotécios, quando comparados com linhagens normais para o desenvolvimento dos cleistotécios.

\subsection{Instabilidade Genética}

Os estudos sobre Instabilidade Genética em fungos tiveram início na década de 50 com Roper (1952), Pontecorvo et al (1954) e Barnett \& De Serres (1963), demostrando que determinados sítios no genoma são mais sucessíveis a mutações espontâneas, existindo analogia ente instabilidade genética e mutações espontâneas em determinados alelos mutantes. Essa instabilidade pode ser considerada alelo específica, 
possuindo alta probabilidade de ocorrer uma mutação para um estado mais estável, sendo essa mutação independente de fatores externos.

A instabilidade genética pode ser originada por processos de alterações cromossômicas numéricas como aneuploidias (Kafer, 1960) sendo que esse processo ocorre por não disjunção mitótica. Azevedo e Roper (1970) obtiveram um variante deteriorado $\mathrm{V} 8$, originado espontaneamente da linhagem A de $A$. nidulans, que apresentava uma alta freqüência de não disjunção mitótica espontânea, quando comparados com as linhagens padrões A e MSE de $A$. nidulans. Análises genéticas realizadas por esses autores, demostram que V 8 é um dissômico para o grupo de ligação III. A linhagem A de A. nidulans e o V 8 somente se diferenciam quanto à presença de um gene que causa alteração na morfologia da colônia de V 8 que está localizado no grupo de ligação IV. Este gene parece ser responsável pela freqüência de dissômicos, possivelmente devido ao aumento de não disjunção mitótica do grupo de ligação III.

Outro processo que afeta a instabilidade genética consiste nas aberrações cromossômicas estruturais, como exemplo as duplicações. Um dos primeiros trabalhos realizados, envolvendo esse tipo de aberração, foi realizado por Bainbridge e Roper (1966), onde através de cruzamentos de pais normais originou uma nova variedade que apresentava menor taxa de crescimento e segregação constante, sendo denominada de "crinkled" (enrugada). Colônias do tipo "crinkled" são instáveis vegetativamente, devido à duplicação cromossômica que carrega (III $\rightarrow \mathrm{VIII}$ ), levando à formação de setores melhorados que ocorrem em maior freqüência e outro tipo de setor, o deteriorado, que ocorre em menor freqüência. Os variantes melhorados provavelmente originam da perda do segmento duplicado, enquanto que os setores deteriorados ocorre uma nova duplicação em tandem.

Segundo Nga \& Roper (1969), os setores melhorados e deteriorados são típicos de linhagens duplicadas, uma vez que linhagens normais e translocadas não apresentam setor. Nga \& Roper (1966) propuseram algumas explicações para esses acontecimentos, como deleções terminais, mutação, permuta mitótica e permuta desigual entre cromátides irmãs. 
O termo " não conformidade genética " (Nga \& Roper, 1968; Azevedo \& Roper, 1970), foi proposto para explicar o desequilíbrio que ocorre nos segmentos cromossômicos, que são responsáveis pela instabilidade genética.

A linhagem A de $A$. nidulans, com segmento duplicado e translocado (I $\rightarrow$ II) (Nga \& Roper, 1968), possui os marcadores genéticos para coloração dos conídios na região duplicada, além de marcas para requerimento nutricional, prolina e ácido $\rho$ aminobenzóico. Ests linhagem origina três tipos de setores:

a. Setores Melhorados são caracterizados por um melhor crescimento e estabilidade, quando comparados com a linhagem A. Esse tipo de setor origina-se pela perda parcial ou total do segmento em duplicata. A perda pode ser intersticial que ocorre em maior freqüência no segmento translocado. Dependendo de que região em duplicata for perdida, ocorre formação de conídios verdes ou amarelos (Nga \& Roper, 1968; Favraud, 1984, Monteiro, 1989, Queiroz, 1988).

b. Setores deteriorados apresentam textura e coloração variável, onde o grau de instabilidade pode ser maior ou menor em relação à linhagem, contendo a duplicação. Podem originar-se, por inversão, novas duplicações em tandem ou transposições do segmento em duplicata (Nga \& Roper, 1968; Azevedo e Roper, 1970, Favraud, 1984).

c. Setores heterocarióticos ocorrem em baixa freqüência. Apresentam uma mistura não usual de conidióforos com conídios verdes e amarelos e conidióforos individuais, contendo tanto conídios verdes quanto amarelos. ( Nga \& Roper, 1969; Favraud, 1984).

Azevedo \& Roper (1970), estudando setores deteriorados da linhagem A de $A$. nidulans, caracterizaram esses setores morfologicamente por possuírem uma taxa de crescimento menor em relação à linhagem duplicada pela produção de conídios reduzida e pela variação no grau de pigmentação da colônia. Os autores sugerem que o caráter deteriorado é resultante da perda total ou parcial da duplicação cromossômica com posterior inserção desse segmento em qualquer um dos oito grupos de ligação de $A$. 
nidulans, o que distingue e caracteriza cada um deles. Esse sistema de instabilidade é muito semelhante aos elementos de transposição de milho, bactérias e drosófilas, podendo ser considerado um relato de transposon em fungos.

Trabalhos realizados por Clutterbuck (1970) associaram a instabilidade genética com mutantes para o locus bristle $(b r l)$, o qual é responsável por uma mutação para o desenvolvimento do conidióforo. Estudos demostraram que uma translocação está presente nesse alelo, que se apresenta variegada. Esta translocação está provavelmente no final do cromossomo III que é heterocromático e a associação deste com um segmento eucromático do cromossomo VIII causaria a variegação do locus bristle.

Há diversos fatores que afetam a instabilidade genética, como fatores químicos, como a cafeína que aumenta a instabilidade (Azevedo, 1975), p-fluorfenilalanina (Lhoas, 1961), benlate (Hastie, 1970) e fatores físicos como temperatura (Lieber, 1976; Favraud, 1984), radiação não ionizante como ultravioleta (Menezes, 1974; Azevedo, 1975). Os fatores genéticos também podem influenciar na instabilidade genética, como o efeito do gene bncAl, que origina conídios bi e trinucleados (Pizzirani-Kleiner \& Azevedo, 1986b), que reduz a instabilidade mitótica na linhagem A de $A$. nidulans e aumenta a instabilidade com relação à freqüência de setores deteriorados produzidos (Pascon, 1994).

Além desse efeito na instabilidade, o gene bncAl origina conídios bi e trinucleados. Esse processo já analisado por Pizzirani-Kleiner \& Azevedo (1986 a), ocorre quando um ou dois núcleos presentes no conidióforo migram para o conídio, formando os bi ou trinucleados, mas, quando apenas um núcleo migra para o conídio, ele não se divide mitoticamente, mantendo-se uninucleado. Além desse efeito, o gene bncAl causa uma série de anormalidades durante a formação do conidióforo como septação de fiálides, número reduzido e desorganização de métulas e fiálides (Pascon, 1994; Giancoli, 1997). 


\section{MATERIAL E MÉTODOS}

\subsection{Linhagens utilizadas}

a. Linhagem $\mathrm{A}$ - com os marcadores genéticos: pro $\mathrm{A}_{1}$, paba $_{6}$ e $\mathrm{o}$ segmento duplicado do cromossomo I e translocado para o cromossomo II (Nga \& Roper, 1968).

b. Linhagem MSE - com os marcadores genéticos: $w \mathrm{~A}_{3}, f a c \mathrm{~A}_{303}$, galA $_{1}$, yA $_{1}$, pyroA $_{4}, s \mathrm{~B}_{3}$, nic $\mathrm{B}_{6}$ e ribo (McCully \& FORBES, 1965).

c. Linhagem Abnc - com os marcadores genéticos: proA 1, paba $_{6}$, a duplicação cromossômica I e translocada para o cromossomo II e o gene bnc $\mathrm{A}_{1}$ (Pizzirani, 1977).

d. Linhagem MSE/bnc - com marcadores genéticos iguais à linhagem MSE e o gene bncA1 ( Pizzirani, 1977).

e. Linhagem bi $\mathrm{A}_{1}$ meth $\mathrm{G}_{1}$

f. Variantes deteriorados isolados da linhagem Abnc, VB 7, VB 8, VB 9, VB 10, VB 11

g. Variantes deteriorados isolados da linhagem A, V101, V102, V103 e V104.

* - Os marcadores genéticos significam - mutantes auxotróficos para: pro, prolina; paba, ácido p-aminobenzóico; pyro, piridoxina; $s$, tiossulfato de sódio; nic, nicotinamida; ribo, riboflavina; - $w$ e $y$, mutações para cor branca e amarela dos conídios, respectivamente; bnc, formação de conídios bi e trinucleados. As linhagens A 
e MSE são derivadas da linhagem selvagem de $A$. nidulans, que são originárias do Departamento de Genética da Universidade de Glasgow, Escócia. Essas duas linhagens foram cedidas pelo Departamento de Genética da Universidade de Sheffiel, Inglaterra. A linhagem Abnc foi obtida no Setor de Genética de Microrganismos, ESALQ/USP.

Os marcadores genéticos estão resumidos abaixo:

\begin{tabular}{|c|c|c|}
\hline Grupo de Ligação & $\begin{array}{c}\text { Sigla do Marcador } \\
\text { Genético }\end{array}$ & Marcador Genético \\
\hline I & suAladE20 & $\begin{array}{l}\text { Supressor do mutante } \\
\qquad a d \mathrm{E} 20\end{array}$ \\
\hline I & proA1 & Requer prolina \\
\hline I & pabaA6 & $\begin{array}{l}\text { Requer ácido } \rho- \\
\text { aminobenzóico }\end{array}$ \\
\hline I & ya2 & Conídios amarelos \\
\hline II & ade20 & Requer adenina \\
\hline II & $b i \mathrm{~A} 1$ & Requer biotina \\
\hline II & wa3 & Conídios brancos \\
\hline III & galA1 & $\begin{array}{c}\text { Incapacidade de utilizar } \\
\text { galactose }\end{array}$ \\
\hline IV & bncAl & $\begin{array}{l}\text { Produz conídios bi e } \\
\text { trinucleados }\end{array}$ \\
\hline IV & pyroA4 & Requer pirodoxina \\
\hline $\mathrm{V}$ & $f a c \mathrm{~A} 303$ & $\begin{array}{l}\text { Incapacidade de utilizar } \\
\text { acetato }\end{array}$ \\
\hline VI & $s \mathrm{~B} 3$ & Requer tiossulfato de sódio \\
\hline VII & nicB6 & Requer ácido nicótico \\
\hline VIII & riboB2 & Requer riboflavina \\
\hline
\end{tabular}


3.2. Meios de Cultura

\subsubsection{Meio Mínimo}

Foi preparado de acordo com Pontecorvo et al. (1953).

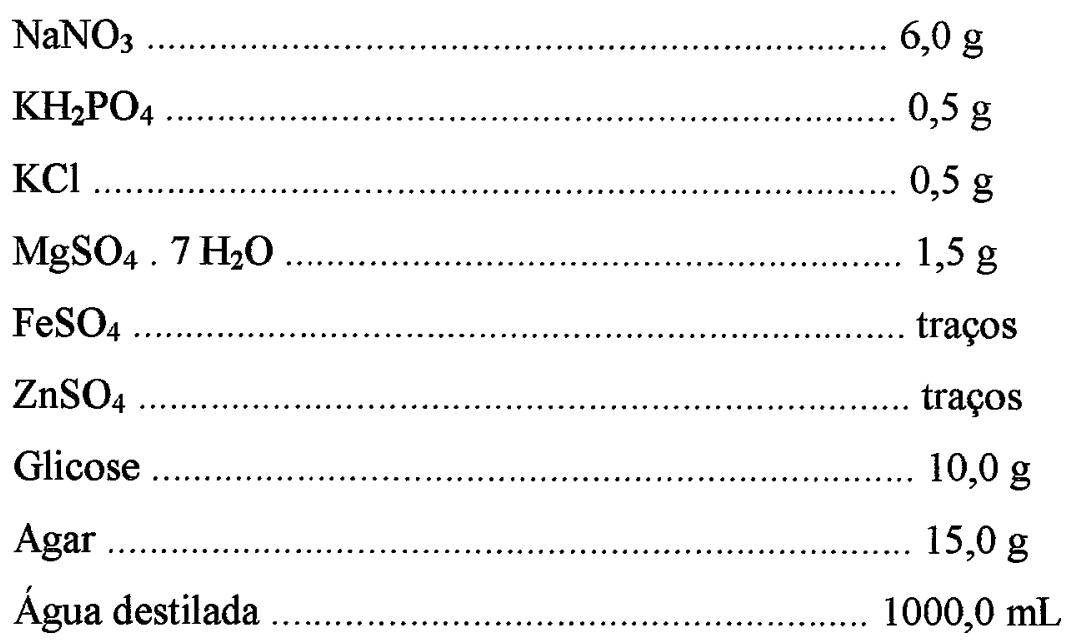

Ajustou o pH para 6,8, utilizando $\mathrm{NaOH} 10 \%$. Autoclavou a 1 atm. por 20 minutos.

\subsubsection{Meio Mínimo líquido}

Foi preparado como descrito no item 3.2.1, sem adição de agar.

\subsubsection{Meio Completo}

Foi preparado de acordo com Pontecorvo et al. (1953) e modificado por Azevedo \& Costa (1973).

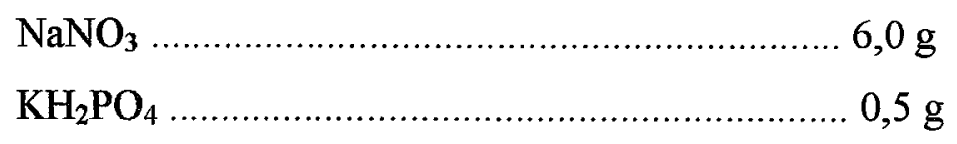




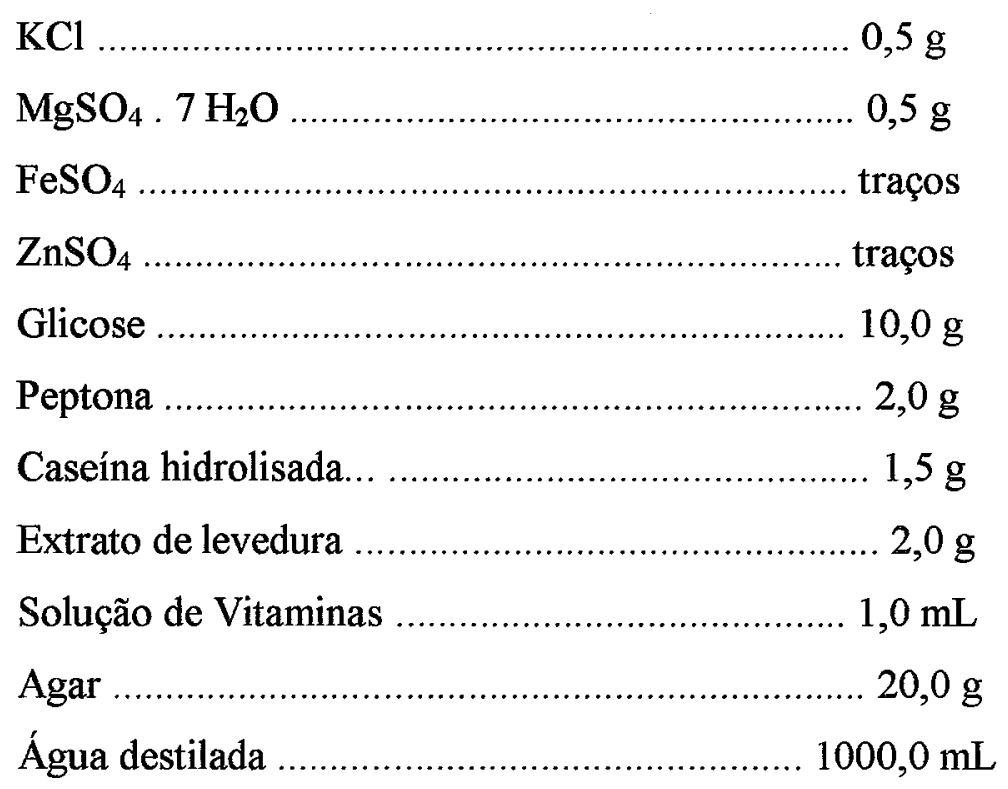

$\mathrm{O}$ pH foi ajustado para 6,8 com $\mathrm{NaOH} 10 \%$. Autoclavou em 1 atm. por 20 minutos.

\subsubsection{Meio Completo pH 5,0}

Foi preparado como descrito no item 3.2.3, sendo que o $\mathrm{pH}$ foi ajustado para 5,0 com $\mathrm{NaOH} 10 \%$

\subsubsection{Meio Completo $\mathrm{pH} 5,8$}

Foi preparado como descrito no item 3.2.3, sendo que o $\mathrm{pH}$ foi ajustado para $5,8 \mathrm{com} \mathrm{NaOH} 10 \%$ 


\subsubsection{Meio Completo líquido}

Foi preparado como descrito no item 5.2.3., sem adição de agar.

\subsubsection{Meio Mínimo líquido acrescido de $2 \%$ de Meio Completo}

Foi preparado de acordo com Pontecorvo et al. (1953).

Adicionou ao meio mínimo líquido $2 \%$ de meio completo líquido. Distribuiu em tubos de ensaio com $2,5 \mathrm{~mL}$ dessa mistura. Autoclavou os tubos de ensaio em 1 atm por 20 minutos.

\subsubsection{Meio de Acetato de Amônio}

Foi preparado de acordo com Aspiron (1962).

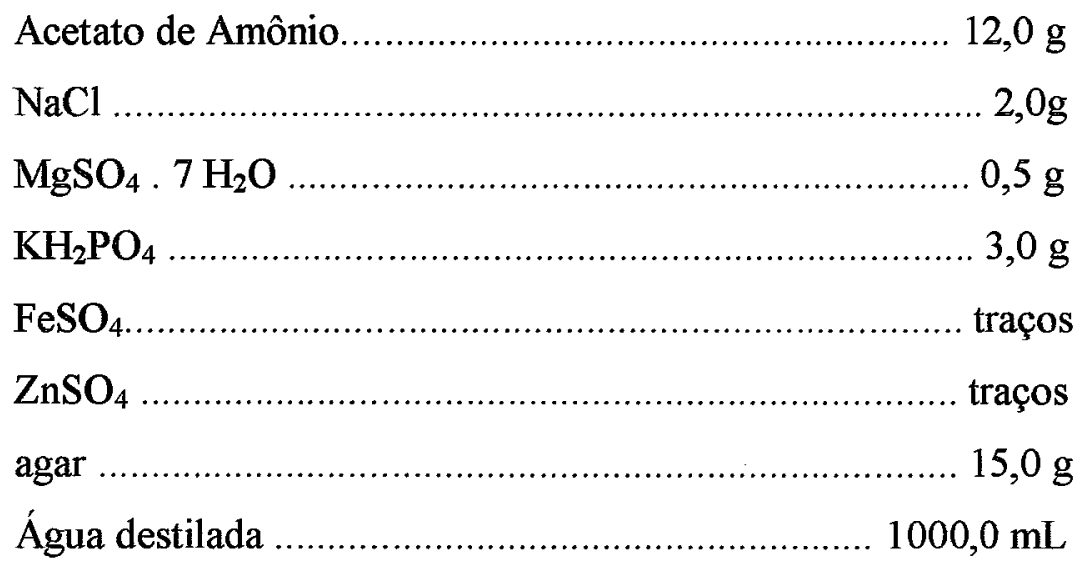

Ajustou o pH para 6,8 com $\mathrm{NaOH} 10 \%$. Autoclavou em $1 \mathrm{~atm}$. por 20 minutos. 
3.2.9. Meio de Galactose.

Foi preparado de acordo com Roberts (1959)

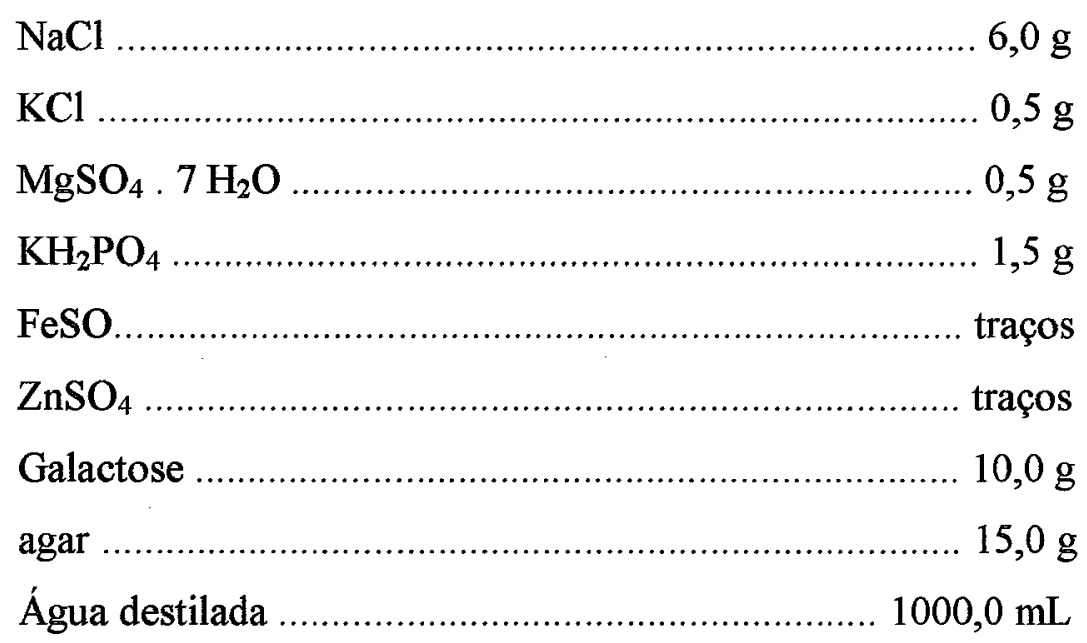

Ajustou o $\mathrm{pH}$ para 6,8 com $\mathrm{NaOH} 10 \%$. Autoclavou a $1 \mathrm{~atm}$. por 20 minutos.

\subsubsection{Meio Completo com $\mathrm{NaCl}$ (Clutterbuck, 1972)}

O estabilizador osmótico utilizado foi $\mathrm{NaCl}$ 0,5 $\mathrm{M}$ para esse meio, sendo que foi feita uma solução estoque de $\mathrm{NaCl} 5 \mathrm{M}$ autoclavada em 1 atm por 20 minutos e mantida a $4^{\circ} \mathrm{C}$. Esta solução foi crescida ao meio já autoclavado.

3.2.11. Meio Completo com solução de $\mathrm{KCl} 0,6 \mathrm{M}$ em tampão fosfato pH 5,0.

$\mathrm{O}$ estabilizador osmótico utilizado foi $\mathrm{KCl}$ 0,6 $\mathrm{M}$ em tampão fosfato $\mathrm{pH} 5,0$. Foi feita uma solução estoque de $\mathrm{KCl} 6 \mathrm{M}$ autoclavada em 1 atm por 20 minutos e mantida a $4^{\circ} \mathrm{C}$. Essa solução foi crescida ao meio já autoclavado. 
3.2.12. Meio Completo com solução de $\mathrm{KCl} 0,6 \mathrm{M}$ em tampão fosfato $\mathrm{pH} 5,8$

O estabilizador osmótico utilizado foi $\mathrm{KCl} 0,6 \mathrm{M}$ em tampão fosfato $\mathrm{pH} 5,8$. Foi feita uma solução estoque de $\mathrm{KCl} 6 \mathrm{M}$ autoclavada em 1 atm por 20 minutos e mantida a $4^{\circ} \mathrm{C}$. Essa solução foi crescida ao meio já autoclavado.

3.2.13. Meio Completo com solução de $\mathrm{KCl} 0,6 \mathrm{M}$ em tampão fosfato $\mathrm{pH} \mathrm{7,0}$

$\mathrm{O}$ estabilizador osmótico utilizado foi $\mathrm{KCl} 0,6 \mathrm{M}$ em tampão fosfato $\mathrm{pH} 7,0$. Foi feita uma solução estoque de $\mathrm{KCl} 6 \mathrm{M}$ autoclavada em 1 atm por20 minutos e mantida a $4^{\circ} \mathrm{C}$. Essa solução foi crescida ao meio já autoclavado.

\subsection{Soluções}

3.3.1. Solução de vitaminas

Ácido nicótico $10,0 \mathrm{mg}$

Ácido $\rho$-aminobenzóico ....................................... 1,0 mg

Biotina ......................................................... $0,02 \mathrm{mg}$

Piridoxina ....................................................... 5, $5 \mathrm{mg}$

Riboflavina ................................................ 10,0 mg

Tiamina ....................................................... 5,0

Água destilada .............................................. 10,0 mL 
Adicionou as vitaminas à água destilada, previamente esterelizada levou essas solução obtida ao banho-maria por 15 minutos e conservou as soluções em refrigerador, em frasco escuro, com clorofórmio.

\subsubsection{Solução de Tween 80}

Tween 80

$0,1 \mathrm{~mL}$

Água destilada $100,00 \mathrm{~mL}$

Dissolveu o tween em água destilada e transferiu a solução para tubos de ensaio com 2,5 mL cada um. Autoclavou em 1 atm. por 20 minutos.

\subsubsection{Solução Salina}

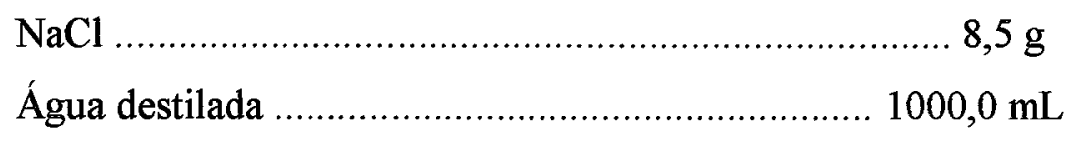

Foi colocado o volume de $9,0 \mathrm{~mL}$ por frasco e autoclavou em 1 atm por 20 minutos.

3.3.4. Solução de Benlate (metil-butil-carbamoil-2-benzimedazole carbamato.

Foi preparada de acordo com Hastie (1970) Benlate ( $50 \%$ de Benomyl ) ............................. 20,0 mg Água destilada $10,0 \mathrm{~mL}$ 
Adicionou benlate em água destilada, previamente esterelizada, levou a solução ao banho-maria por 15 minutos. Depois de pronta, a solução foi mantida em refrigerador.

\subsubsection{Solução de suplementos adicionais para o meio mínimo.}

Preparou-se uma solução estoque para cada um dos suplementos. Essas foram preparadas com água destilada na qual se adiciona a droga. Depois, foram, levadas ao banho-maria por 15 minutos e depois foram guardadas sob refrigeração.

Adição dos componentes dos requisitos nutricionais ao Meio Mínimo para Análise Genética

\begin{tabular}{ccc}
\hline \hline Solução Estoque & $\mathrm{Mg} / 100 \mathrm{~mL} \mathrm{de} \mathrm{H}_{2} \mathrm{O}$ & $\begin{array}{c}\text { Concentração final no meio de } \\
\text { cultura }(\mu \mathrm{g} / \mathrm{mL})\end{array}$ \\
\hline Adenina & 500,00 & 25,00 \\
Ácido Nicotínico & 10,00 & 0,50 \\
Ácido p-aminobenzóico & 5,00 & 0,25 \\
Biotina & 4,00 & 20,00 \\
Metionina & 1000,00 & 50,00 \\
Piridoxina & 5,00 & 0,25 \\
Prolina & 1000,00 & 50,00 \\
Riboflavina & 10,0 & 0,50 \\
Tiossulfato de Sódio & 2000,00 & 100,00 \\
\hline \hline
\end{tabular}




\subsubsection{Tampão Fosfato $0,2 \mathrm{M} \mathrm{pH} \mathrm{7,0}$}

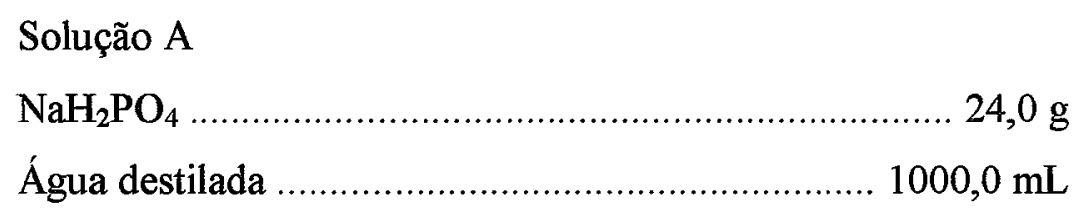

Solução B

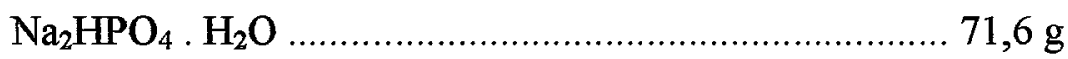

Água destilada ............................................. 1000,0 mL

Misturou a solução $\mathrm{A}$ com a solução $\mathrm{B}$, até obter o $\mathrm{pH} 7,0$. Conservou solução A e B sob refrigeração a $4^{\circ} \mathrm{C}$. O tampão fosfato é preparado no momento do uso.

\subsubsection{Tampão fosfato $0,2 \mathrm{M} \mathrm{pH} 5,8$}

Foi preparado como descrito no item 3.3.6, ajustou o $\mathrm{pH}$ para 5,8.

\subsubsection{Tampão fosfato $0,2 \mathrm{M} \mathrm{pH} 5,0$}

Foi preparado como descrito no item 3.3.6 e ajustou o pH para 5,0 .

\subsubsection{Solução de $\mathrm{KCl} 0,6 \mathrm{M} \mathrm{pH} \mathrm{7,0}$}

Colocou 44,7 g de $\mathrm{KCl}$ em cerca de $350 \mathrm{~mL}$ de solução A. Aqueceu até dissolver o $\mathrm{KCl}$, adicionou, então, a solução $\mathrm{B}$ até $\mathrm{pH} 7,0$. Acertou o volume próximo a $1000,0 \mathrm{~mL}$ com o tampão fosfato $0,2 \mathrm{M} \mathrm{pH} \mathrm{7,0.} \mathrm{Ajustou} \mathrm{o} \mathrm{pH}$ final 
para 7,0 com solução A ou B conforme o caso, até o volume final de $1000,0 \mathrm{~mL}$. A solução foi autoclavada em $1 \mathrm{~atm}$ por 20 minutos e conservada em refrigerador a $4^{\circ} \mathrm{C}$.

\subsubsection{Solução de $\mathrm{KCl} 0,6 \mathrm{M} \mathrm{pH} \mathrm{5,8}$}

Foi preparado como descrito no item 3.3.9, mas com tampão fosfato $0,2 \mathrm{M} \mathrm{pH} \mathrm{5,8,} \mathrm{e} \mathrm{o} \mathrm{pH} \mathrm{final} \mathrm{da} \mathrm{solução} \mathrm{foi} \mathrm{ajustado} \mathrm{para} \mathrm{5,8.}$

\subsubsection{Solução de $\mathrm{KCl} 0,6 \mathrm{M} \mathrm{pH} \mathrm{5,0}$}

Foi preparado como descrito no item 3.3.9, mas com tampão fosfato $0,2 \mathrm{M} \mathrm{pH} \mathrm{5,0,} \mathrm{e} \mathrm{o} \mathrm{pH} \mathrm{final} \mathrm{da} \mathrm{solução} \mathrm{foi} \mathrm{ajustado} \mathrm{para} \mathrm{5,0.}$

\subsubsection{Solução de fixação}

\begin{tabular}{|c|c|}
\hline ácido acético glacial . & $\ldots 1,0 \mathrm{~mL}$ \\
\hline ido lático & \\
\hline
\end{tabular}

A solução de fixação foi preparada no momento de uso dentro de capela de exaustão.

\subsubsection{Solução de $\mathrm{HCl} 1 \mathrm{~N}$}

$\mathrm{HCl}$ concentrado $82,5 \mathrm{~mL}$ Água destilada $1000,0 \mathrm{~mL}$ 
A solução foi mantida em frasco escuro à temperatura ambiente.

\subsubsection{Solução Estoque Giemsa}

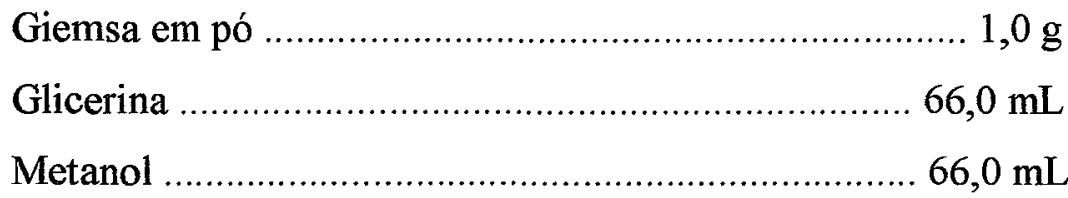

Misturou o Giemsa com glicerina a $60^{\circ} \mathrm{C}$. Após resfriamento, adicionou o metanol, filtrou a solução e armazenou à temperatura ambiente em frasco escuro.

\subsubsection{Solução Corante}

tampão fosfato $0,2 \mathrm{M} \mathrm{pH} \mathrm{7,0}$ $10,0 \mathrm{~mL}$

Solução de Giemsa $2,0 \mathrm{~mL}$

Preparar a solução corante apenas no momento do uso.

\subsubsection{Solução de Albumina 5\%}

Preparou-se uma solução com $5 \mathrm{~mL}$ de clara de ovo em $95 \mathrm{~mL}$ de água destilada, filtrando-se e conservando-a em frasco escuro a $4^{\circ} \mathrm{C}$.

3.3.17. Fixação de fungos para Microscopia Eletrônica de Varredura (MEV) 
Paraformaldeído $10 \%$......................................... $20 \mathrm{~mL}$

Tampão cacodilato $0,2 \% \mathrm{pH} \mathrm{7,2} \mathrm{\ldots \ldots \ldots \ldots \ldots \ldots \ldots \ldots \ldots ...................} 25 \mathrm{~mL}$

$\mathrm{CaCl}_{2}$ 0,1 M ............................................ 1,0 mL

Água destilada .............................................. $44 \mathrm{~mL}$

Misturou-se todos os reagentes. A solução foi mantida sob refrigeração a $4^{\circ} \mathrm{C}$.

3.3.18. Tampão Cacodilato de sódio $0,2 \mathrm{M}, \mathrm{HCl} \mathrm{0,1} \mathrm{M}$ pH 7,4

Cacodilato de sódio $42,8 \mathrm{~g}$

Água destilada $1000,0 \mathrm{~mL}$

O cacodilato de sódio foi dissolvido em $900,0 \mathrm{~mL}$ de água destilada, o $\mathrm{pH}$ foi ajustado para 7,2 com $\mathrm{HCl} 1 \mathrm{~N}$ e o volume foi completado para $1000,0 \mathrm{~mL}$ com água destilada. Essa solução foi mantida a $4^{\circ} \mathrm{C}$.

\subsubsection{Solução de Tetróxido de ósmio}

Foi preparada de acordo com SESSO et al. (1989)

Lavou-se a ampola de ósmio por 1 hora em solução sulfocrômica. Retirou a solução sulfocrômica e lavou a ampola em água destilada por 30 minutos. Em seguida, lavou a ampola com água destilada várias vezes, colocando-a em frasco com $100 \mathrm{~mL}$ de tampão cacodilato $0,1 \mathrm{M} \mathrm{pH} \mathrm{7,4} \mathrm{e} \mathrm{quebrando-a} \mathrm{com} \mathrm{um} \mathrm{bastão} \mathrm{de} \mathrm{vidro.}$ Deixou "overnight" à temperatura ambiente para dissolver o ósmio. Estocou a solução em temperatura ambiente em frasco escuro. De preferência esse frasco dever ser guardado dentro de uma lata, isto porque o tetróxido de ósmio é extremamente volátil, sendo um potente fixador de mucosas. 


\subsection{Técnicas de Análise Genética}

3.4.1. Isolamento dos setores deteriorados da linhagem A e Abnc de $A$. nidulans

$\mathrm{O}$ isolamento de setores deteriorados da linhagem $\mathrm{A}$ e Abnc de $A$. nidulans foi realizado pela inoculação de conídios com alça de platina no centro de placas de Petri com meio completo. As placas de Petri foram incubadas com os inóculos por 7 dias a $37^{\circ} \mathrm{C}$.

\subsubsection{Obtenção de heterocários}

Para obtenção de heterocários (análise genética via ciclo sexual e parassexual), foram adicionados conídios das linhagens a serem cruzadas (aproximadamente $10^{7}$ de conídios $/ \mathrm{mL}$ ) em tubos de ensaio, contendo meio mínimo acrescido de $2 \%$ de meio completo. A incubação foi realizada por 72 horas a $37^{\circ} \mathrm{C}$.

\subsubsection{Isolamento de diplóides}

Foi utilizado método descrito por Roper (1952).

Para isolamento dos diplóides, o método usado para obtenção dos heterocários foi descrito no item 3.4.2. Após a formação de película heterocariótica, essa foi transferida para uma placa de Petri contendo meio mínimo, a qual foi incubada durante sete dias a $37^{\circ} \mathrm{C}$. Após esse período, os conídios foram coletados com auxílio de uma alça de platina e colocados em um tubo de ensaio com tween 80 a fim de se obter uma concentração de $1 \times 10^{7}$. Essa suspensão de conídios foi diluída várias vezes e semeada em meio mínimo. 
Os conídios, que germinaram no meio mínimo, ou eram diplóides ou heterocarióticos, sendo que as colônias provenientes de conídios heterocatióticos possuem um fenótipo característico que puderam ser facilmente distinguidas das colônias provenientes de conídios diplóides. Os critérios que foram utilizados para caracterização de diplóides foram:

a. capacidade de crescer em meio mínimo;

b. coloração da colônia;

c. tamanho do conídio.

O diâmetro dos conídios foi calculado com base nas medidas obtidas por meio de ocular micrométrica.

\subsubsection{Análise mitótica via Ciclo Parassexual}

Foi utilizado método descrito por Azevedo \& Costa (1973) e Pizzirani-Kleiner et al (1998).

As colônias haplóides, que foram utilizadas para a análise mitótica, foram obtidas por meio de haploidização dos diplóides isolados pela metodologia descrita no item 3.4.3. Uma forma de agilizar o processo de haploidização é por meio de uso de agentes haploidizantes como Benomyl $(1,4 \mu \mathrm{g} / \mathrm{mL})$ o qual age na divisão mitótica, provocando a perda de grupos de ligação das duas linhagens ao acaso. Esse agente haploidizante foi adicionado à placa de Petri com meio completo e os diplóides foram incubados nestas placas por ponto, sendo que os setores haplóides gerados no processo de haploidização foram purificados por, no mínimo, 2 ciclos de incubação por estrias em meio completo. Após 8 dias de incubação a $37^{\circ} \mathrm{C}$, as colônias selecionadas foram transferidas para uma placa mestra com 26 pontos e a mesma foi testada para todos os marcadores genéticos envolvidos na análise com auxílio de um replicador multifio (Azevedo et. al., 1976). As leituras da análise genética foram efetuadas após 24 e 48 horas de crescimento a $37^{\circ} \mathrm{C}$. 


\subsubsection{Análise Meiótica via Ciclo Sexual}

Para análise meiótica foi utilizado o método descrito por Pontecorvo et. al. (1953).

À indução do ciclo sexual os heterocários foram preparados de acordo com o item 3.4.3, sendo as placas de Petri vedadas com fita adesiva. Após 8 dias de incubação a $37^{\circ} \mathrm{C}$, as placas foram analisadas sob microscópio estereoscópio para verificar a presença de corpos de frutificação, os cleistotécios. Foram selecionados os cleistotécios maiores e mais escuros, os quais foram "rolados" em placa, contendo agar e água destilada e esterelizada para a retirada de células adjacentes, as células de Hüller.

Os cleistotécios escolhidos e limpos foram transferidos para tubo de ensaio contendo solução Tween 80 . Os cleistotécios foram esmagados contra a parede do tubo, com ajuda de uma pipeta esterelizada. Os ascósporos em suspensão foram diluídos em 9,0 mL de solução salina e o volume de $0,1 \mathrm{~mL}$ semeado em placas de Petri, contendo meio completo. A incubação foi feita por 72 horas. Após esse período, as colônias foram purificadas por estrias e inoculadas em placa mestra com 26 pontos, de onde foram transferidas com replicador multifio (Azevedo et. al., 1976) para os meios seletivos para testes com marcadores genéticos específicos. Foram feitas duas leituras em 24 e 48, horas respectivamente.

Os dados que foram obtidos pela análise do ciclo sexual permitem-nos a organização dos marcadores em grupos de ligação. Para sabermos se dois locis estarão ligados ou não, aplicou-se a fórmula abaixo e foi utilizado também o teste de $\mathrm{X}^{2}$ para análise da segregação.

$$
\begin{aligned}
& \mathrm{C}=\mathrm{R} \times 100 / \mathrm{t} \\
& \text { onde: } \\
& \mathrm{C}=\text { frequência de recombinação } \\
& \mathrm{R}=\text { número de colônias recombinantes } \\
& \mathrm{T}=\text { número total de colônias analisadas }
\end{aligned}
$$




\subsection{Técnicas da análise citológicas}

\subsubsection{Conidiogênese}

O estudo das estruturas morfológicas durante o desenvolvimento assexual de $A$. nidulans foi feito, separadamente, pela semeadura dos conídios das linhagens padrões MSE, A, MSE/bnc e Abnc e dos variantes deteriorados originários das linhagens A e Abnc, em placa de Petri, contendo meio completo. Sobre o meio completo com os conídios já semeados, foram colocados pequenos retângulos de membrana de diálise e lamínula previamente esterelizadas em autoclave, e incubado a $37^{\circ} \mathrm{C}$ por intervalos de tempo pré-determinados de $16,20,24,28,30,32,34,38,42,46$, $50,54,64$ horas. Nos tempos determinados, os blocos com meio completo e membrana de diálise foram cortados e estocados em refrigerador, repetindo-se o processo até o último tempo determinado e então foram submetidos à análise citológica.

\subsubsection{Coloração do Núcleos}

Foi utilizado método descrito por Paes de Barros (1977), modificado por Luna (1985).

Para a coloração de núcleo em diferentes estágios de desenvolvimento assexual, as colônias foram crescidas sobre membrana de diálise e lamínula, em intervalos de tempo pré-determinados. A fixação foi feita com solução de álcool e ácidos (item 3.3.12), durante 15 minutos. Em seguida, as membranas ou lamínulas passaram por uma série alcoólica (etanol 90\%,70\% e 50\%), de 5 minutos para cada concentração. A hidrólise foi realizada com $\mathrm{HCl} 1 \mathrm{~N}$ por 15 minutos a $63^{\circ} \mathrm{C}$ em banho-maria. Após este processo de hidrólise, as membranas de diálise foram lavadas em água destilada, por 3 vezes durante 10 minutos. A tamponagem do sistema foi realizada com tampão fosfato $0,2 \mathrm{M}$ pH 7,0 (item 3.3.6) durante 1 hora. A coloração foi feita, adicionando-se $2,0 \mathrm{~mL}$ de Giemsa a $10,0 \mathrm{~mL}$ de tampão fosfato $0,2 \mathrm{M} \mathrm{pH} \mathrm{7,0}$ 
durante 15 minutos para a membrana de diálise. Após a coloração, as membranas de

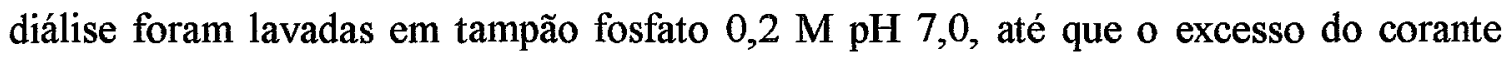
fosse retirado. A montagem da lâmina foi realizada, colocando a membrana de diálise sobre a lâmina e lamínula.

\subsubsection{Coloração de Conídios}

Os conídios foram inoculados em meio completo, e após cinco dias de incubação a $37^{\circ} \mathrm{C}$. Em seguinda, foram colocados em uma lamínula, contendo uma gota de albumina 5\%, homogeneizados e espalhados pela lamínula, fazendo-se preparações citológicas deles, seguindo-se o método descrito no item 3.5.2.

3.5.4. Método de fixação e desidratação de fungos para Microscopia Eletrônica de Varredura (MEV).

Foi realizado o estudo morfológico das linhagens MSE, A, MSE/bnc e Abnc e dos variantes deteriorados originário das linhagens A e Abnc, através de Microscopia Eletrônica de Varredura (MEV). Essas análises foram executadas no Núcleo de Apoio à Pesquisa em Microscopia Eletrônica aplicada à pesquisa Agropecuária (NAP/MEPA), centro localizado na Escola Superior de Agricultura 'Luís de Queiroz" ESALQ/USP.

Separadamente, conídios de cada linhagem foram inoculados no centro das placas de Petri, contendo meio completo. Ao redor do ponto de inoculação, foram colocados retângulos de membranas de diálise, previamente esterilizadas e incubadas a $37^{\circ} \mathrm{C}$ por 4 dias. Após esse período, as membranas de diálise foram retiradas e colocadas em eppendorfs com solução para fixação de microscopia eletrônica (item 3.3.17), por uma hora em temperatura ambiente. Ao final desse período, as amostras em membrana de diálise foram retiradas e colocadas em tampão cacodilato 
0,05 M (item 3.3.18), por 15 minutos, com três repetições. Seguindo o processo, as membranas de diálise foram colocadas em solução de tetróxido de ósmio (3.3.18) diluído 1:1 com água destilada, permanecendo no mínimo por uma hora. Após a retirada do tetróxido de ósmio, as membranas foram lavadas com água destilada (3 lavagens de 5 minutos cada uma). A desidratação foi efetuada em bateria crescente de acetona ( $10 \%$, $30 \%, 50 \%, 70 \%, 90 \%$ por 15 minutos e a acetona $100 \%$ com três repetições de 15 minutos). As amostras foram submetidas à secagem a ponto crítico em aparelho Balzers CPD 030 e, a seguir, as membranas foram montadas em sttubs com fita de carbono. As amostras foram metalizadas com uma fina camada de ouro, através do aparelho Evaporador MED 010 da Balzers. As amostras prontas foram observadas no Microscópio Eletrônico de Varredura Leo 435 VP. 


\section{RESULTADOS E DISCUSSÃO}

4.1. Obtenção espontânea de setores deteriorados, originários das linhagens A e Abnc de Aspergillus nidulans

$\mathrm{O}$ isolamento dos setores deteriorados foi realizado por inoculação da linhagem A e Abnc, obtida no estoque do laboratório de Genética de Microrganismos Dept. de Genética ESALQ/USP, por um ponto central em placa de Petri, contendo meio completo e incubado a $37^{\circ} \mathrm{C}$ por 7 dias.

Os dados provenientes do isolamento de 150 colônias da linhagem A podem ser observados na Tabela 1. Esse dados, quando comparados com outros autores (Tabela 4), demostram uma grande variação entre os números médios de setores obtidos. Essas diferenças não são devidas apenas ao tamanho das amostras, mas também a interferências da temperatura (Favraud, 1984; Lieber, 1976). Para obtenção de um número maior de setores deteriorados, Favraud (1984) determinou que a temperatura mais indicada seja de $37^{\circ} \mathrm{C}$.

As variações ambientais, como temperatura e nutricionais como mudanças no preparo do meio de cultura, explicariam os baixos valores obtidos nesse trabalho sobre a instabilidade da linhagem A, a qual obteve o total de 1,12 setores/placa (Tabela 1) e, comparando esses dados com outros autores (Tabela 4), temos uma valor máximo de 3,75 setores/placa (Oliveira, 1982) e valor mínimo de 1,08 (Pascon, 1994) setores/placa para a linhagem A. Os dados provenientes do isolamento de 150 colônias da linhagem Abnc podem ser observados na Tabela 2. Pizzirani-Kleiner (1981) que analisando setores dessa mesma linhagem, obteve o total de 1,3 setores/placa, enquanto que Pascon 
(1994) obteve a média de 1,45 setores/placa. $O$ valor obtido nesse trabalho foi de 0,23 setores/placa, valor muito baixo quando comparado com as autoras citadas. As explicações para esse fato consistem em variações ambientais e nutricionais, além da linhagem utilizada nesse trabalho ter sido resgatada do estoque do setor de Genética de Microrganismos da ESALQ/USP, enquanto que a linhagem utilizada por Pascon (1994) foi reconstruída, podendo ter ocorrido mudanças no "background" genético. Para comparar os dados obtidos com o isolamento de setores deteriorados da linhagem Abnc, realizou a reconstrução de uma nova linhagem Abnc, a partir do cruzamento via ciclo sexual, selecionado um recombinante com as características da linhagem Abnc do estoque. Os dados provenientes do isolamento de setores dessa nova linhagem podem ser vistos na Tabela 3 , foram analisadas o total de 133 colônias, inoculadas por ponto central em placa de Petri, contendo meio completo, e incubadas por sete dias a $37^{\circ} \mathrm{C}$. Essa nova linhagem Abnc apresentou uma média de 0,73 setores por placa, sendo comparada com os dados obtidos anteriormente por Pizzirani-Kleiner (1981) e Pascon (1994), apresentando uma baixa instabilidade genética, mas, em relação à linhagem utilizada do estoque, apresentou uma alta na instabilidade. Com esses dados, fica claro que a instabilidade genética das linhagens com duplicação cromossômica apresenta grandes variações, além disso a linhagem Abnc possui a mutação do gene bncAl que diminui a instabilidade genética (Pascon, 1994).

Azevedo \& Roper (1970) e Azevedo (1971, citados por Monteiro, 1989), analisaram 31 setores originados de linhagem com duplicação cromossômica e classificaram-nos em quatro grupos:

a. determinantes de deterioração associados com deleção no grupo de ligação I;

b. determinantes de deterioração localizados em outros grupos de ligação, que não estão envolvidos na duplicação;

c. determinantes de deterioração localizados no segmento translocado com novas duplicações em tandem;

d. determinantes de deterioração muito instáveis, que são analisados apenas pelos setores que emitem. 
Tabela 1. Freqüência total de Setores da linhagem A, obtida neste trabalho após inoculação por ponto central e incubação por 7 dias a $37^{\circ} \mathrm{C}$

\begin{tabular}{cccc}
\hline \hline Setores & $\mathrm{N}^{\mathrm{o}}$ Observado & Freqüência & $\mathrm{N}^{\mathrm{o}}$ médio por colônia \\
\hline Melhorados & 133 & 0,79 & 0,890 \\
Deteriorados & 13 & 0,07 & 0,087 \\
Heterocarióticos & 22 & 0,14 & 0,147 \\
Total & 168 & 1,00 & 1,124 \\
\hline \hline
\end{tabular}

Tabela 2. Freqüência total de Setores da linhagem Abnc, obtida neste trabalho após inoculação por ponto central e incubação por 7 dias a $37^{\circ} \mathrm{C}$.

\begin{tabular}{cccc}
\hline Setores & $\mathrm{N}^{\mathrm{o}}$ Observado & Freqüência & $\mathrm{N}^{\mathrm{o}}$ médio por colônia \\
\hline Melhorados & 0 & 0 & 0 \\
Deteriorados & 22 & 0,65 & 0,146 \\
Heterocarióticos & 12 & 0,35 & 0,084 \\
Total & 34 & 1,00 & 0,23 \\
\hline
\end{tabular}

Tabela 3. Freqüência total de Setores da linhagem Abnc reconstruída, obtida neste trabalho após inoculação por ponto central e incubação por 7 dias a $37^{\circ} \mathrm{C}$.

\begin{tabular}{cccc}
\hline Setores & $\mathrm{N}^{\mathrm{o}}$ Observado & Freqüência & $\mathrm{N}^{\mathrm{o}}$ médio por colônia \\
\hline Melhorados & 72 & 0,734 & 0,54 \\
Deteriorados & 23 & 0,235 & 0,17 \\
Heterocarióticos & 3 & 0,031 & 0,02 \\
Total & 98 & 1,00 & 0,73 \\
\hline \hline
\end{tabular}




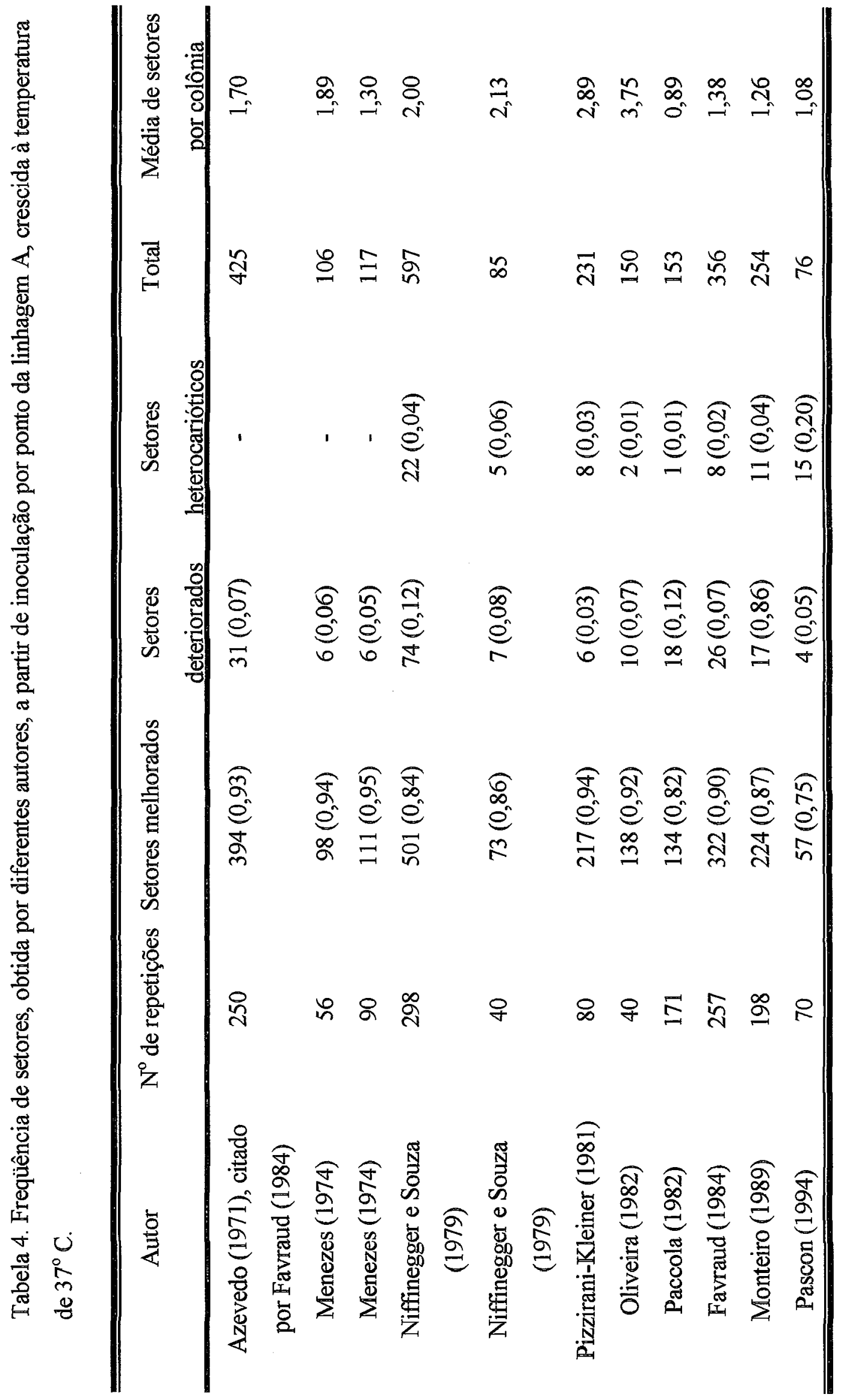




\subsection{Características Morfológicas dos Setores Deteriorados}

O 13 Setores deteriorados, obtidos a partir da linhagem A, foram purificados em meio completo por estrias e incubados a $37^{\circ} \mathrm{C}$ por 5 dias. Dos 13 setores deteriorados isolados, 6 setores reverteram durante as purificações, sendo que, dos 7 setores que foram purificados, foram escolhidos 4 setores que possuem aspecto morfológico mais diferenciado do padrão (Tabela 5 e Figura 1).

Tabela 5. Descrição dos aspectos morfológicos dos variantes deteriorados, provenientes da linhagem A.

\begin{tabular}{|c|c|}
\hline Variante deteriorado & Morfologia \\
\hline V 101 & $\begin{array}{l}\text { Borda irregular, micélio marrom muito claro, esporulação } \\
\text { pequena, esporos com coloração branca, fundo da placa com } \\
\text { coloração avermelhada }\end{array}$ \\
\hline V 102 & $\begin{array}{l}\text { Borda regular, micélio branco, esporulação pequena, esporos } \\
\text { com coloração verde, fundo da placa com coloração } \\
\text { avermelhada. }\end{array}$ \\
\hline V 103 & $\begin{array}{l}\text { Borda regular, cor do micélio branco, esporulação pequena, } \\
\text { esporo com coloração verde, fundo da placa com } \\
\text { coloração vermelho - escura. }\end{array}$ \\
\hline V 104 & $\begin{array}{l}\text { Borda regular, cor do micélio branca, baixa esporulação, } \\
\text { esporos com coloração branca, fundo da placa com coloração } \\
\text { avermelhada. }\end{array}$ \\
\hline
\end{tabular}



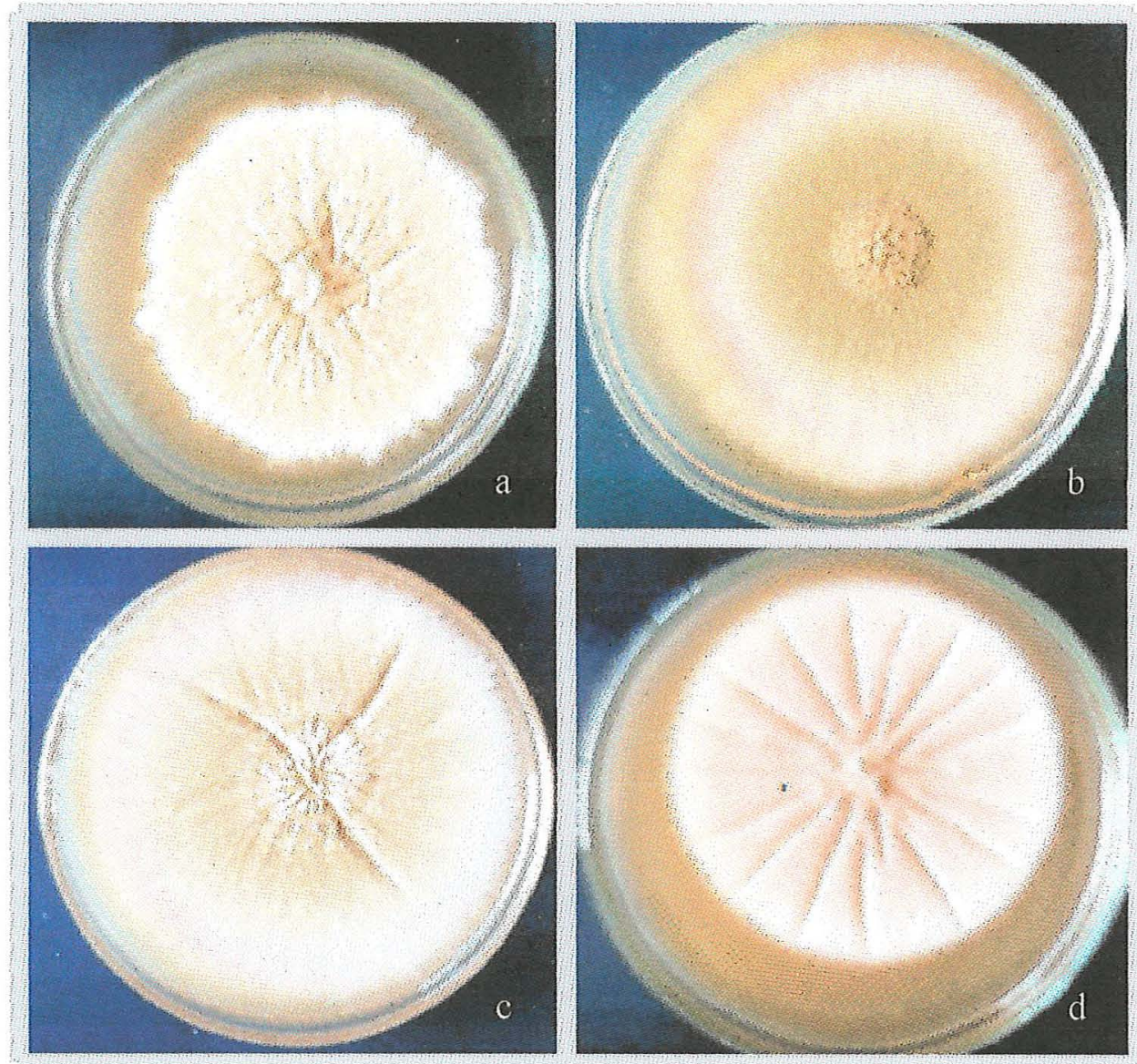

Figura 1. Aspectos Morfológicos dos Variantes Deteriorados originários da linhagem A; a. V 101, b. V 102, c. V 103, d. V 104. 
Os 22 Setores deteriorados, obtidos a partir da linhagem Abnc, foram purificados em meio completo por estrias e incubados a $37^{\circ} \mathrm{C}$ por 5 dias, 13 setores deteriorados durante as purificações reverteram, sendo que dos 9 setores foram purificados, sendo escolhidos 5 setores que possuem aspecto morfológico mais diferenciado do padrão (Tabela 6 e Figura 2).

Tabela 6. Descrição dos aspectos morfológicos dos variantes deteriorados, proveniente da linhagem Abnc.

\begin{tabular}{cl}
\hline \hline Variante deteriorado & \multicolumn{1}{c}{ Morfologia } \\
\hline VB7 & Borda regular, micélio marrom muito claro, esporulação um \\
pouco menor que os padrões, esporos de coloração branca, \\
fundo da placa marrom avermelhado \\
VB8 & Borda regular, micélio branco, esporulação pequena, esporos \\
& com coloração branca, fundo da placa rosa-vermelhado. \\
VB9 & Colônia com crescimento limitado, borda regular, cor do \\
& micélio branco, esporulação relativamente baixa, esporo com \\
& coloração verde, fundo da placa vermelho escuro. \\
VB10 & Borda regular, cor do micélio branca, baixa esporulação, \\
& esporos com coloração branca, fundo da placa claro. \\
VB11 & esporos com coloração branca, fundo da placa claro. \\
&
\end{tabular}




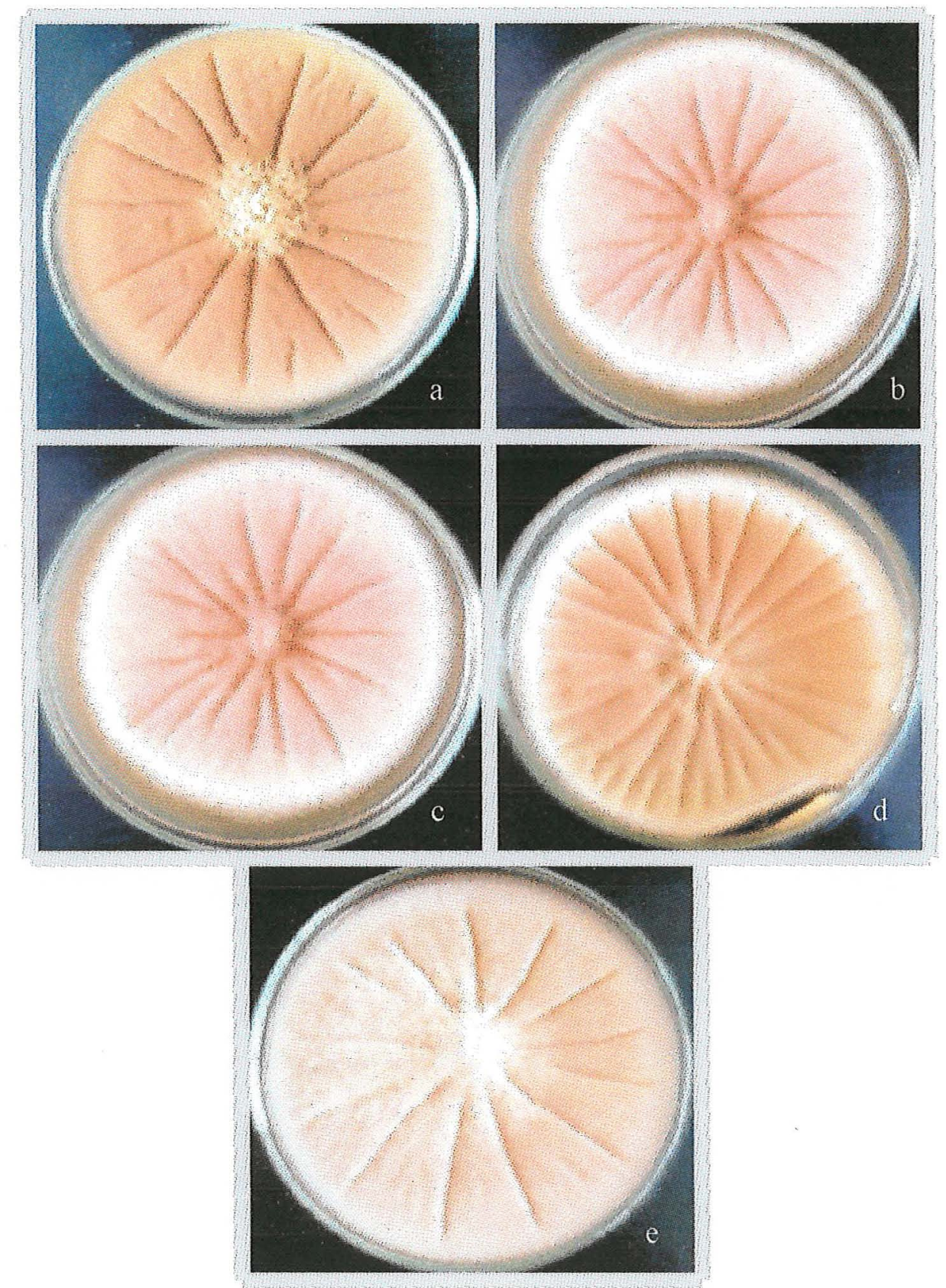

Figura 2. Aspecto Morfológico dos Variantes Deteriorados originários da linhagem Abnc; a. VB 7, b. VB 8, c. VB 9, d. VB 10, e. VB 11. 
4.2.1 Teste de auxonografia dos Variantes Deteriorados provenientes das linhagens A e Abnc

Foi realizada a auxonografia dos Variantes Deteriorados provenientes das linhagens A e Abnc e da linhagens utilizadas como padrão para os cruzamentos (Tabela 7), para confirmação dos marcadores auxotróficos.

Tabela 7. Auxonografia dos Variantes deteriorados e das linhagens padrões utilizados neste trabalho

\begin{tabular}{cccccccccccc}
\hline \hline Linhagens & Pro & paba & gal & Fac & pvro & s & nic & ribo & Bi & Met \\
MSE & + & + & - & - & - & - & - & - & - & + \\
MSE/bnc & + & + & - & - & - & - & - & - & - & + \\
bi meth & + & + & + & + & + & + & + & + & - & - \\
A & - & - & + & + & + & + & + & + & + & + \\
Abnc & - & - & + & + & + & + & + & + & + & + \\
Abnc & - & - & + & + & + & + & + & + & + & + \\
V 101 & - & - & + & + & + & + & + & + & + & + \\
V 102 & - & - & + & + & + & + & + & + & + & + \\
V 103 & - & - & + & + & + & + & + & + & + & + \\
V 104 & - & - & + & + & + & + & + & + & + & + \\
VB7 & - & - & + & + & + & + & + & + & + & + \\
VB8 & - & - & + & + & + & + & + & + & + & + \\
VB9 & - & - & + & + & + & + & + & + & + & + \\
VB10 & - & - & + & + & + & + & + & + & + & + \\
VB11 & - & - & + & + & + & + & + & + & + & + \\
\hline \hline
\end{tabular}


4.2.2. Porcentagem de conídios bi e trinucleados dos Variantes Deteriorados da linhagem Abnc.

Pizzirani-Kleiner (1981), estudando os efeitos do gene $b n c \mathrm{~A}_{1}$, determinou que todas as linhagens com menos de $99 \%$ de conídios uninucleados são consideradas portadoras do gene $b n c A_{1}$. Em suas análises, foi obtida uma média de 78,21 conídios uninucleados, 21,55 conídios binucleados e 0,24 conídios trinucleados na linhagem MSE/bnc, sendo que para a linhagem Abnc obteve uma média de 60,54 de conídios uninucleados; 36,40 conídios binucleados e 3,06 conídios trinucleados. Por outro lado, análises realizadas por Pascon (1994), com a mesma linhagem determinaram uma média de 77,51 conídios uninucleados, 22,4 conídios binucleados e 0,09 conídios trinucleados. Essa diferença entre as duas autoras foi explicada pelo fato que Pascon (1994) utilizou uma linhagem reconstruída, o que pode ter levado a alguma alteração. No presente trabalho, utilizou-se a linhagem Abnc proveniente do estoque, isto é, a mesma utilizada por Pizzirani-Kleiner (1981), sendo que os dados obtidos podem ser observados na Tabela 8 .

Tabela 8. Porcentagem de conídios bi e trinucleados dos variantes deteriorados da linhagem Abnc.

\begin{tabular}{ccccc}
\hline \hline Linhagens & \% uninucleado & \% binucleado & \% trinucleado & Total \\
\hline MSE & 100 & - & - & 340 \\
A & 100 & - & - & 413 \\
MSE/bnc & 87,7 & 11,8 & 0,5 & 930 \\
Abnc & 84,4 & 15,2 & 0,4 & 888 \\
VB7 & 89,0 & 10,8 & 0,2 & 882 \\
VB8 & 98,2 & 1,7 & 0,1 & 952 \\
VB9 & 91,9 & 7,9 & 0,2 & 843 \\
VB10 & 92,1 & 7,7 & 0,2 & 988 \\
VB11 & 97,2 & 2,6 & 0,2 & 531 \\
\hline \hline
\end{tabular}


As variações que ocorrem em relação à porcentagem de conídios uni, bi e trinucleados, quando comparadas com Pizzirani-Kleiner (1981) e Pascon (1994) podem ser consideradas normais, devido a variações ambientais e genéticas que possam ter ocorrido com a linhagem MSE/bnc e Abnc, as quais foram recuperadas do estoque do laboratório de Genética de Microrganismos da ESALQ/USP. Para análise neste trabalho, foram consideradas as linhagens padrões MSE, MSE/bnc, A e Abnc. A contagem dos conídios foi realizada após coloração de Giemsa - $\mathrm{HCl}$. Foram realizadas três repetições. As linhagens A e MSE apresentam uma porcentagem de $100 \%$ de conídios uninucleados e que, por esta razão foram utilizadas como padrões.

\subsubsection{Resposta da conidiação dos Variantes Deteriorados} provenientes da linhagem Abnc frente a estabilizadores osmóticos e $\mathrm{pH}$.

A mensuração da conidiação foi realizada em função de uma área de $50,26 \mathrm{~mm}^{2}$

A resposta da conidiogênese a diferentes pHs e estabilizadores osmóticos foi estudada por Clutterbuck (1969 e 1970), que observou que a conidiogênese melhora com a presença de estabilizadores osmóticos, sendo potencializada por pHs baixos. Essa sensível melhora envolve a formação de conidióforos menos aberrantes e com maior quantidade de conídios. Em mutantes bristle, isto foi explicado em relação à proteína bristle que atua como regulador de transcrição de DNA, sendo que essas condições (temperatura, pHs e estabilizadores osmóticos) poderiam aumentar a afinidade da proteína bristle pelo DNA, melhorando as anormalidades das estruturas e conidiação do conidióforo (Timberlake \& Clutterbuck, 1994).

Molina e Azevedo (1989) observaram que variantes deteriorados isolados da linhagem A e inoculados em meio completo mais estabilizadores osmóticos demostravam um fenótipo normal. Esses autores sugerem que a aparência enrugada desses variantes deteriorados tiveram origem pela dificuldade de absorção de alguns componentes do meio, provavelmente devido a alterações na membrana plasmática. $O$ 
estabilizador osmótico repararia o erro, permitindo o desenvolvimento normal da colônia

Molina (1993) realizou ensaios com diversos meios de culturas suplementados com estabilizadores osmóticos em variantes deteriorados originários da linhagem A. Observou uma reversão na coloração da linhagens (verde ou amarela), na presença de $\mathrm{MC}$ com $\mathrm{KCl}$. $\mathrm{O}$ estudo quantitativo realizado por essa autora mostra um aumento na esporulação no meio completo com tampão fosfato mais $\mathrm{KCl}$, determinando uma influência positiva da esporulação.

Rocha (1997), estudando linhagens mutantes (CLB 3) para o gene bristle com estabilizador osmótico $\mathrm{NaCl} 0,5 \mathrm{M}$ e temperaturas variadas $\left(25^{\circ} \mathrm{C}\right)$, observou uma melhora apenas na quantidade de conidióforo e não nas alterações das estruturas morfológicas que os compõem.

Neste trabalho, realizararm-se ensaios com dois estabilizadores osmóticos, tampão fosfato acrescido de $\mathrm{KCl}$ 0,6 M (Molina, 1993) com os pHs 5,0; 5,8 e 6,8, e $\mathrm{NaCl}$ 0,5 M (Clutterbuck, 1969; Rocha, 1997), com três repetições para cada linhagem analisada. Os resultados da descrição morfológica desses ensaios podem ser observados na tabela 9. Foi utilizado como padrão o meio de cultura completo $\mathrm{pH} 6,8$, descrito por Pontecorvo (1953). A descrição morfológica das linhagens assim como as mensurações da conidiação podem ser observadas nas Tabela 9 e 10.

Em relação à morfologia macroscópica (Tabela 9) das colônias em diferentes $\mathrm{pHs}$, observou-se uma reversão parcial da coloração dos deteriorados, para a coloração verde, o mesmo ocorrendo com outros estabilizadores osmóticos utilizados. O VB 8 apresentou uma considerável redução no tamanho da colônia, quando crescido em meio completo suplementado com $\mathrm{NaCl} 0,5 \mathrm{M}$ e meio completo suplementado com $\mathrm{KCl} \mathrm{0,6} \mathrm{M} \mathrm{pH} \mathrm{6,8.}$

A mensuração da conidiação está representada na Tabela 10 em conídios/mL. De maneira geral, comparando as médias obtidas, observa-se um aumento na conidiação em meios completos suplementados com tampão fosfato mais $\mathrm{KCl} 0,6 \mathrm{M}$ com diferentes $\mathrm{pHs}$. Observou-se que a mutação do gene $b n c \mathrm{~A}_{1}$ não influência na mensuração em meio completo $\mathrm{pH}$ 6,8 (utilizado como meio de cultura padrão), sendo que a redução da quantidade de conídios deve-se ao determinante de deterioração, como 
foi observado em outros trabalhos (Azevedo \& Roper, 1970; Niffinegger-Souza, 1979; Queiroz, 1988; Monteiro, 1989; Pascon, 1994).

Pascon (1994), analisando citologicamente a morfologia de variantes deteriorados proveniente da linhagem Abnc, observou que o estabilizador osmótico $\mathrm{KCl}$ 0,6 M é capaz de alterar a morfologia dos variantes deteriorados, tornando os conidióforos mais ricos em quantidades de esterígmas, mas as características morfológicas conferidas à mutação do gene $b n c \mathrm{~A}_{1}$ continuam.

Neste trabalho, o estudo citológico da conidiogênese do conidióforo não foi realizado, não sendo possível verificar a ocorrência de melhora ou piora na formação das estrutura que compõem o conidióforo. 
ก
ก

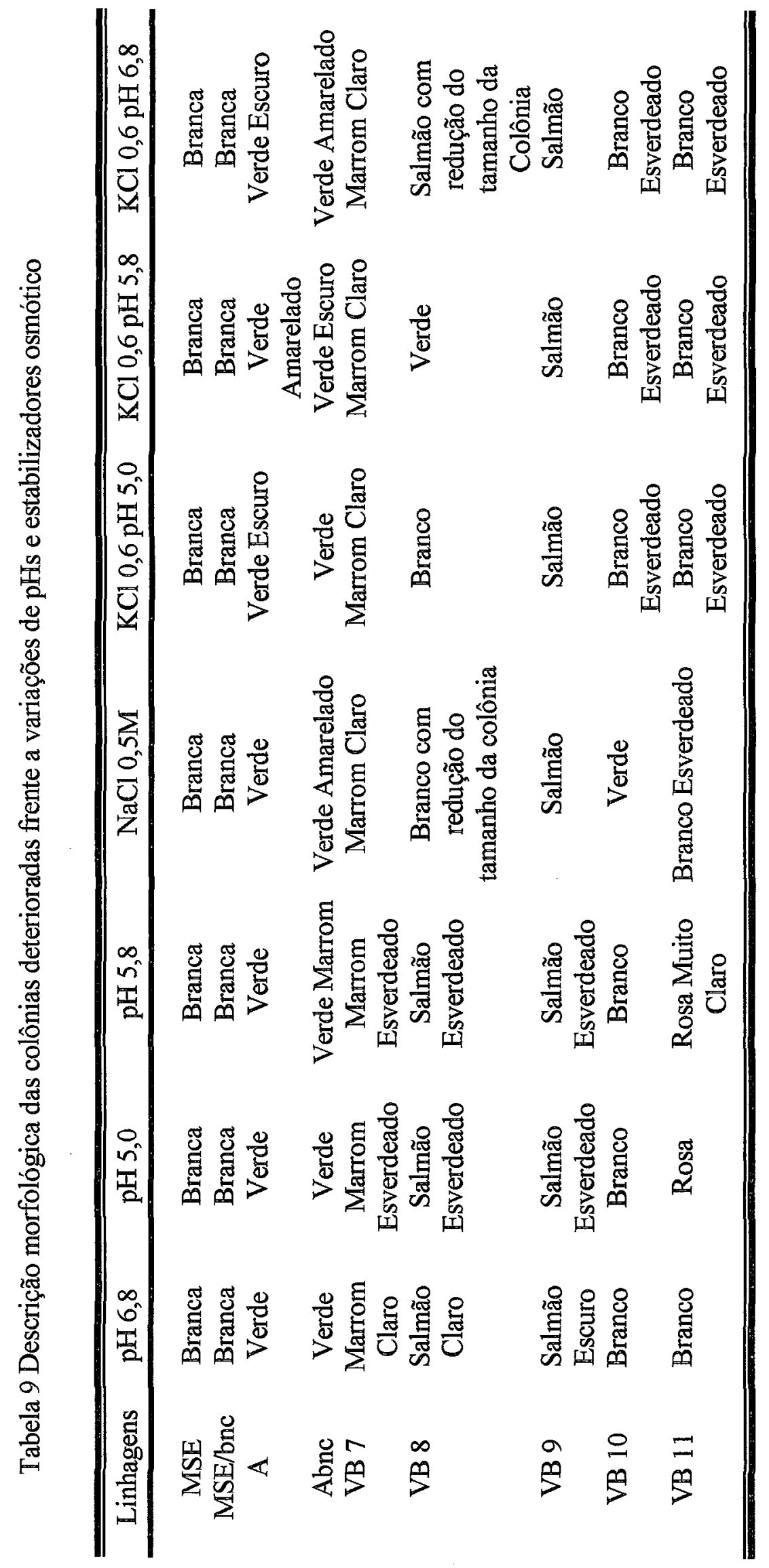




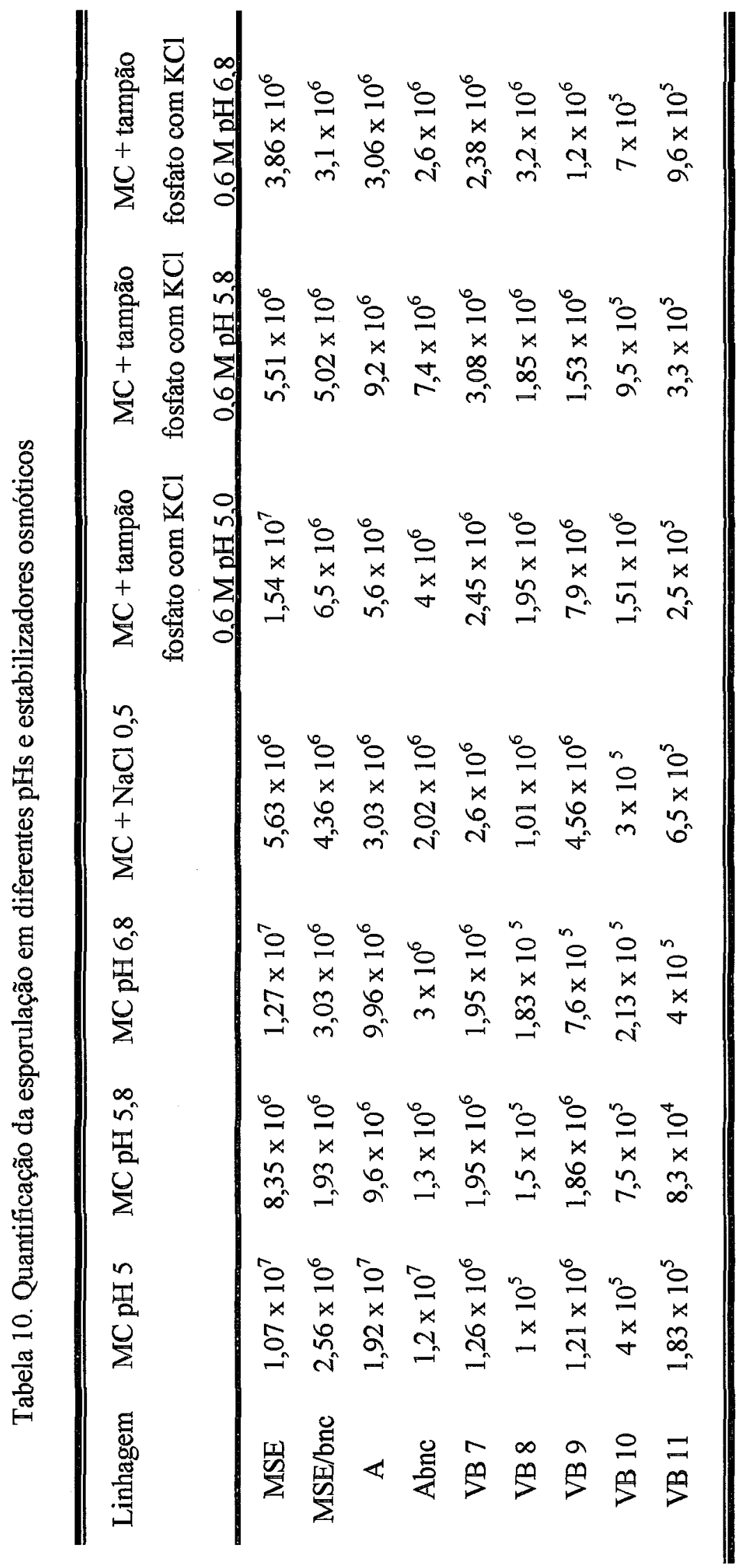


4.2.4. Medidas do diâmetro dos núcleos e conídios dos Variantes Deteriorados provenientes das linhagens A e Abnc.

Elliot (1960) estudou a citologia do fungo $A$. nidulans, determinou a ocorrência de oito cromossomos, sendo três grandes (um deles com satélite), dois de tamanho médio, dois pequenos e um muito pequeno. $O$ estudo citológico desse fungo, raramente é realizado, devido ao pequeno tamanho de seus cromossomos, mas observações citológicas, como medição de conídios e núcleos, são fundamentais para observar as diferenças existentes entre diferentes linhagens e a relação de ploidia das linhagens.

Neste trabalho, foram realizadas as medições do diâmetro dos conídios e núcleos, após coloração com Giemsa - $\mathrm{HCl}$. Foram utilizadas apenas linhagens haplóides, sendo consideradas como linhagens padrões: MSE, bi meth, A, MSE/bnc e Abnc. As medições foram realizadas com ocular micromética, sendo realizadas as medições de 20 conídios, no total de três repetições.

Na tabela 11, observa-se a média das medidas do diâmetro dos conídios. $\mathrm{Na}$ linhagem com duplicação cromossômicas, a linhagem A obteve uma média de $3,76 \mu \mathrm{m}$ de diâmetro sendo a maior média quando comparada às outras linhagens, o que era esperado, devido à duplicação do material genético. Esses dados sobre as medidas do diâmetro de conídios são condizentes aos dados obtidos por Paes de Barros (1977), Niffenegger - Souza (1979), Pacon (1994).

Um dado interessante refere-se à linhagem Abnc, que apresentou neste trabalho a média do diâmetro de 3,20 $\mu \mathrm{m}$ para conídios uninucleados e 4,04 $\mu \mathrm{m}$ para conídios binucleados, média inferior à obtida por Pascon (1994) com 3,95 $\mu \mathrm{m}$ para conídios uninucleados e 4,68 x 5,00 $\mu \mathrm{m}$ para conídios binucleados (conídios ovalados). Uma explicação para esses dados é que Pascon (1994) utilizou uma linhagem reconstruída, enquanto neste trabalho, utilizou a linhagem do estoque do laboratório de Genética de Microrganismos - ESALQ/USP. Pascon (1994) observou que os variantes deteriorados provenientes da linhagem Abnc, assim como as linhagens portadoras da mutação bnc $\mathrm{A}_{1}$, possuem conídios binucleados ovalados, sendo que essa observação não foi confirmada neste trabalho. Pizzirani-Kleiner (1981), realizando medições de conídios e núcleos da 
linhagem MSE/bnc, obteve os valores médios de 3,47 $\mu \mathrm{m}$ para conídios uninucleados e 4,21 $\mu \mathrm{m}$ para conídios binucleados, sendo que dados semelhantes foram obtidos neste trabalho. Na Tabela 11 observa-se a média das medidas realizadas entre o eixo maior e o eixo menor dos conídios.

Tabela 11. Média do diâmetro dos conídios uninucleados e binucleados das linhagens MSE, A, bi meth, MSE/bnc, Abnc, V 101, V 102, V 103, V104, VB 7, VB 8, VB 9, VB 10, VB 11.

\begin{tabular}{ccccc}
\hline \hline \multirow{2}{*}{ Linhagens } & \multicolumn{2}{c}{ Uninucleados } & \multicolumn{2}{c}{ Binucleados } \\
& Médias & Desvio padrão & Médias & Desvio padrão \\
\hline MSE & 3,24 & 0,105 & - & - \\
A & 3,76 & 0,172 & - & - \\
bi meth & 3,42 & 0,142 & - & - \\
V101 & 3,28 & 0,09 & - & - \\
V102 & 3,34 & 0,103 & - & - \\
V103 & 3,30 & 0,140 & - & - \\
V104 & 3,32 & 0,089 & - & - \\
MSE/bnc & 3,65 & 0,363 & 4,31 & 0,322 \\
Abnc & 3,20 & 0,167 & 4,04 & 0,200 \\
VB 7 & 3,34 & 0,308 & 4,06 & 0,200 \\
VB 8 & 2,77 & 0,127 & 3,39 & 0,147 \\
VB 9 & 3,09 & 0,166 & 3,54 & 0,276 \\
VB 10 & 3,03 & 0,237 & 3,88 & 0,213 \\
VB 11 & 2,69 & 0,147 & 3,37 & 0,181 \\
\hline \hline
\end{tabular}


$\mathrm{Na}$ Tabela 12, observa-se a média de 10 amostras com três repetições do diâmetro dos núcleos após coloração de Giemsa - $\mathrm{HCl}$. Entre as linhagens uninucleadas, observou uma variação normal nas medidas do diâmetro. Pizzirani-Kleiner (1981) realizou medições do diâmetro dos núcleos, encontrando para a linhagem MSE/bnc uma média de $1,36 \mu \mathrm{m}$ para os uninucleados e 1,31 $\mu \mathrm{m}$ para binucleados. Neste trabalho foram obtidos dados muito semelhantes com 1,36 $\mu \mathrm{m}$ uninucleados e 1,14 $\mu \mathrm{m}$ para binucleados. Os variantes deteriorados binucleados apresentam uma média de $0,96 \mu \mathrm{m}$ à $1,0 \mu \mathrm{m}$ relação aos uninucleados, que apresentam $1,34 \mu \mathrm{m}$ à $1,24 \mu \mathrm{m}$, demostrando que a diminuição no diâmetro dos núcleos é gradativa com o aumento do número de núcleos.

Tabela 12. Média do diâmetro dos núcleos das linhagens MSE, A, bi meth, MSE/bnc, Abnc, V 101, V 102, V 103, V104, VB 7, VB 8, VB 9, VB 10, VB 11.

\begin{tabular}{ccccc}
\hline \hline Linhagens & \multicolumn{2}{c}{ Uninucleados } & \multicolumn{2}{c}{ Binucleados } \\
& Médias & Desvio padrão & Médias & Desvio padrão \\
\hline MSE & 1,23 & 0,264 & - & - \\
A & 1,34 & 0,061 & - & - \\
bi meth & 1,29 & 0,104 & - & - \\
V101 & 1,23 & 0,116 & - & - \\
V102 & 1,21 & 0,091 & - & - \\
V103 & 1,20 & 0,097 & - & - \\
V104 & 1,20 & 0,117 & - & 0,116 \\
MSE/bnc & 1,36 & 0,097 & 1,14 & 0,103 \\
Abnc & 1,30 & 0,119 & 1,07 & 0,088 \\
VB 7 & 1,34 & 0,087 & 1,00 & 0,102 \\
VB 8 & 1,28 & 0,074 & 0,99 & 0,079 \\
VB 9 & 1,30 & 0,113 & 0,96 & 0,064 \\
VB 10 & 1.24 & 0,061 & 0,96 & 0,181 \\
VB 11 & 1,26 & 0,119 & 1,00 & - \\
\hline \hline
\end{tabular}




\subsection{Conidiogênese}

O fungo homotálico Aspergillus nidulans é considerado um modelo para estudos Genéticos clássicos e moleculares, além de ser um organismo ideal para o estudo da diferenciação celular e desenvolvimento, isto principalmente devido ao ciclo de vida relativamente curto e aos diferentes tipos de mutantes para o desenvolvimento do ciclo assexual.

O início dos estudos sobre a organização espacial do desenvolvimento de Aspergillus nidulans teve início na década de 40 através de Pontecorvo et. al. $(1946,1949 \mathrm{~b}$, 1953) e Roper (1952). Atualmente, diversos pesquisadores têm elucidado uma série de eventos relacionados com a genética do desenvolvimento destacando-se entre eles Timberlake \& Clutterbuck, 1994; Miller, 1992, Oekley, 1992, entre outros.

O estudo da conidiogênese neste trabalho iniciou-se com a comparação morfológica das linhagens consideradas padrões: MSE, A, MSE/bnc, Abnc, sendo as duas últimas portadoras da mutação do gene bncAl que confere núcleos bi e trinucleados aos conídios, assim com os variantes deteriorados que serão analisados, em um período determinado de crescimento de $16,20,24,28,30,32,34,38,42,46,50,54,64$ horas, em placa de Petri com meio completo a $37^{\circ} \mathrm{C}$. Foi utilizada coloração de Giemsa - $\mathrm{HCl}$ (item 3.5.2) para as observações realizadas em microscópio ótico e para Microscopia Eletrônica de Varredura (MEV) foi utilizada fixação básica (item 3.5.4), nos intervalos de 28, 48 e 100 horas.

O estudo da conidiogênese ocorreu em membrana de diálise e lamínula. Foram realizadas três repetições com membrana de diálise e lamínula. $\mathrm{O}$ desenvolvimento em membrana de diálise apresentou melhor resultado, com um crescimento mais acentuado e coloração mais nítida, além de um período de tempo mais curto à coloração. A lamínula apresentou menor quantidade de material desenvolvido, devendo ocorrer isto, provavelmente pelo stresse que a lamínula exerce sobre o desenvolvimento do micélio, uma vez que não há passagem de oxigênio suficiente pela lamínula, podendo isto ser verificado pela grande quantidade de células de Hülle observada nessas preparações, sugerindo que as linhagens submetidas a esse tipo de análise sofra um estresse fisiológico. 


\subsubsection{Comparação entre linhagens MSE, A, MSE/bnc e Abnc}

A comparação da conidiogênese entre as linhagens padrões portadoras do gene $b n c \mathrm{~A} 1$ com as linhagens não portadoras desse gene foi realizada para verificar as diferenças morfológicas que poderiam ocorrer entre elas.

No período de desenvolvimento de 16 horas de incubação, foi possível observar apenas hifas em todas as linhagens analisadas. Além disso com esse intervalo de tempo, ocorria muita perda de material durante a preparação da coloração, sendo que as análises nesse intervalo foram realizada sem coloração.

A partir de 20 horas de incubação, foi possível observar hifas indiferenciadas, em alguns casos hifas diferenciadas em célula pé com haste do conidióforo. A partir de 24 horas, observou-se um número grande de vesículas, sendo que algumas apresentavam brotamento de métulas, e por volta de 28 horas, foi possível observar vários estágios de desenvolvimento do conidióforo. Por volta de 30 - 32 horas, foi possível observar fiálides maduras com desenvolvimento de conídios.

O desenvolvimento temporal e espacial dos conidióforos ocorre após 20 horas de incubação (Axelrod, 1973; Champe et al, 1981).

A partir de 48 horas foi possível observar os conidióforos com longas cadeias de conídios.(Figura 3 ).

As linhagens portadoras do gene bncA1 (Pizzirani-Kleiner, 1981), além de possuírem conídios bi e trinucleados, apresentam outros aspectos interessantes, como: primeiro a respeito da disposição das cadeias de conídios, onde foram encontradas cadeias de conídios apenas uninucleadas e ou apenas binucleadas, raramente foram encontradas cadeias mistas, o que concorda com os resultados obtidos por Pascon (1994); segunda observação ocorre em relação às más formações que ocorrem nas linhagens portadoras da mutação do gene $b n c A_{1}$, como desorganização na distribuição de métulas e fiálides ao longo da vesícula do conidióforo, sendo possível observar um menor número dessas estruturas quando comparadas com as linhagens que não apresentam a mutação $b n c \mathrm{~A}_{1}$. Observou-se que as fiálides formadas são septadas com até três núcleos no seu interior (Figuras 4). 
Clutterbuck (1977) propôs classificações dos genes envolvidos na diferenciação dos conidióforos, onde destaca os genes envolvidos no crescimento e desenvolvimento vegetativo, sendo considerados genes suportes. Dentro deste grupo subdividem-se mais quatro tipos de genes, sendo que o gene $b n c \mathrm{~A}_{1}$ provavelmente se encontra na categorias dos mutantes com modificação do conidióforo (Miller et al, 1992), o qual é composto pelos genes $s t u \mathrm{~A}$ e medA, que causam especificamente alteração na morfologia e na organização espacial do conidióforo, mas não impedem o desenvolvimento dos conídios.

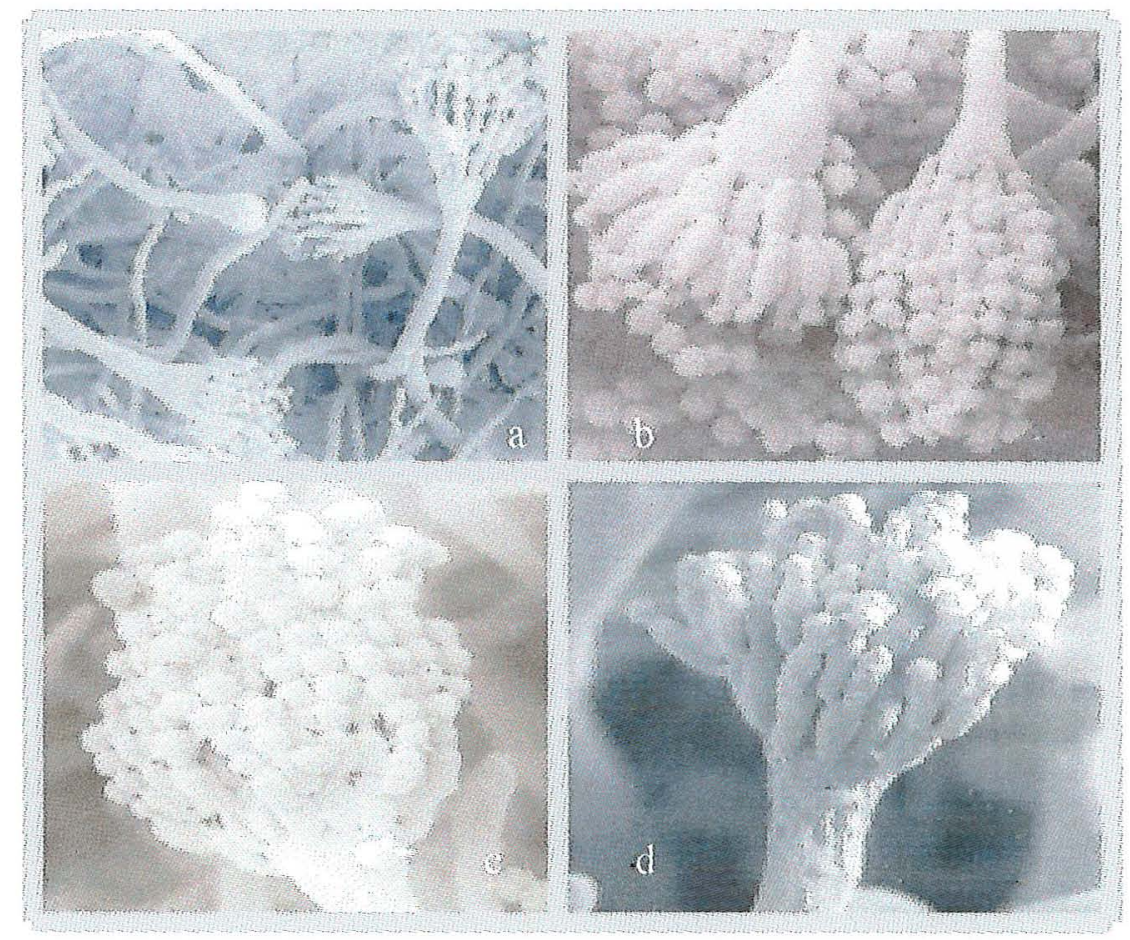

Figura 3. Micrografias de Microscopia Eletrônica çe Varredura das linhagens padrões; a MSE aumentos $1000 \mathrm{x}, \mathrm{b}$. MSE/bnc aumento $2000 \mathrm{x}$; c. linhagem A aumentos $2000 \mathrm{e}$ x; d. Abnc aumentos 2000x. 


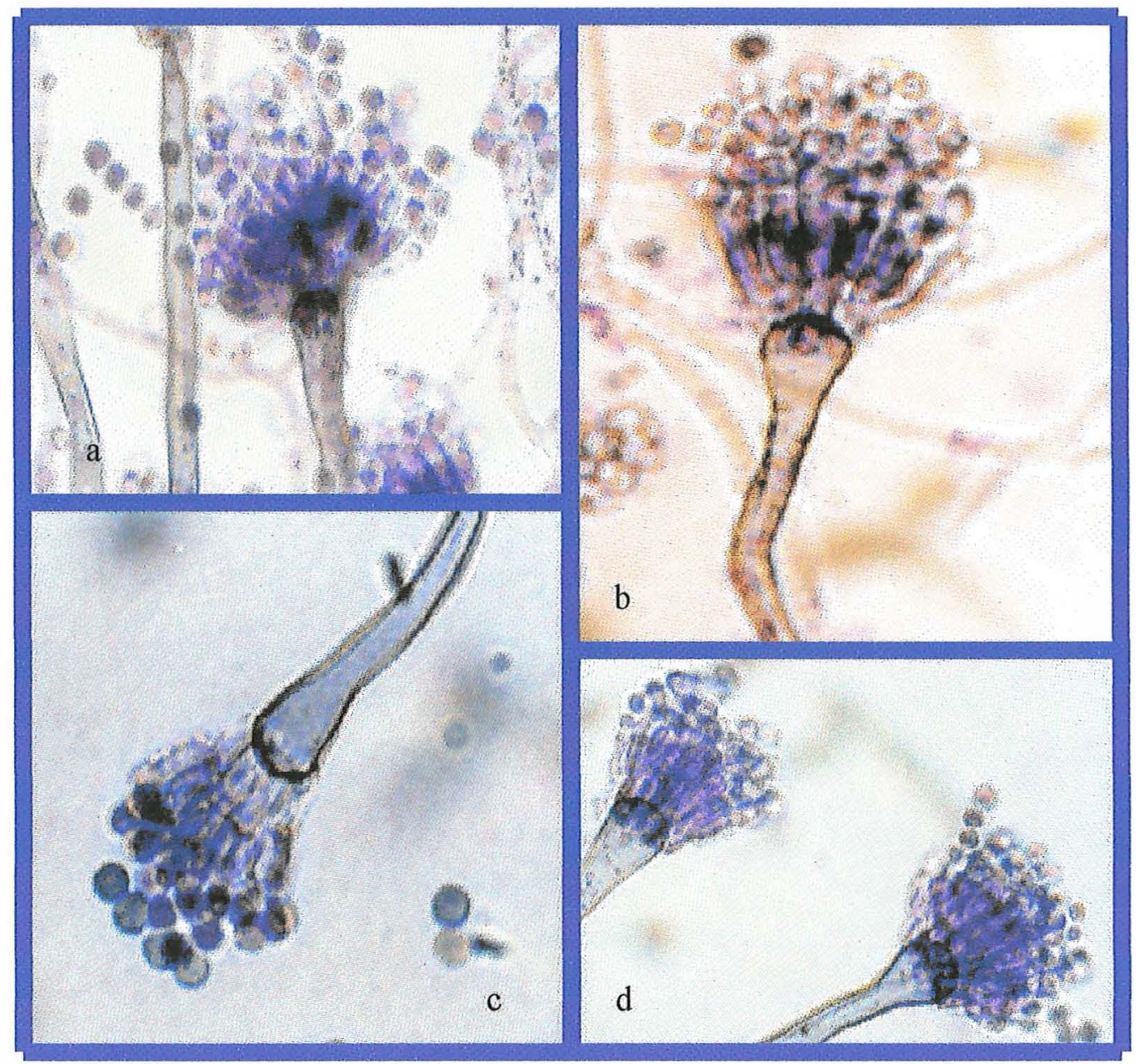

Figura 4. Micrografias de microscopia ótica das linhagens padrões após coloração de Giemsa - HCl. a. linhagem MSE 38 horas; b. linhagem Abnc 38 hora, c.linhagem MSE/bnc 42 horas; d linhagem A 38 hora; d. Aumento 1.000x. 


\subsubsection{Análise Citológica do VB 7}

Para análise dos Variantes Deteriorados foram utilizados os mesmos intervalos de tempo das linhagens padrões.

O VB 7 apresentou tempo de desenvolvimento compatível com as linhagens padrões, com diferenciação das hifas a partir de 20 horas de desenvolvimento. A formação dos conídios ocorre por volta 30 - 32 horas, sendo possível observar pequenas cadeias de conídios uni e binucleados. (Figuras 5 e 6 a). O variante deteriorado VB 7 apresentou uma quantidade menor de conidióforos quando comparado com as linhagens padrões. O desenvolvimento temporal dos conidióforos apresenta um atraso, observando métulas e fiálides em diferentes estágios de desenvolvimento (Figura 6 b).

O desenvolvimento e organização de métulas e fiálides desse deteriorado apresentou desorganização característica, observada nas linhagens portadoras do gene bncA1, além de não diferenciação entre métulas e fiálides (semelhante a um longo dedo), mas sim uma longa estrutura alongada e indiferenciada com pouquíssimos conídios (Figuras $6 \mathrm{~d}$, e, f). Também se observou conidióforos normais (Figura 6 c).

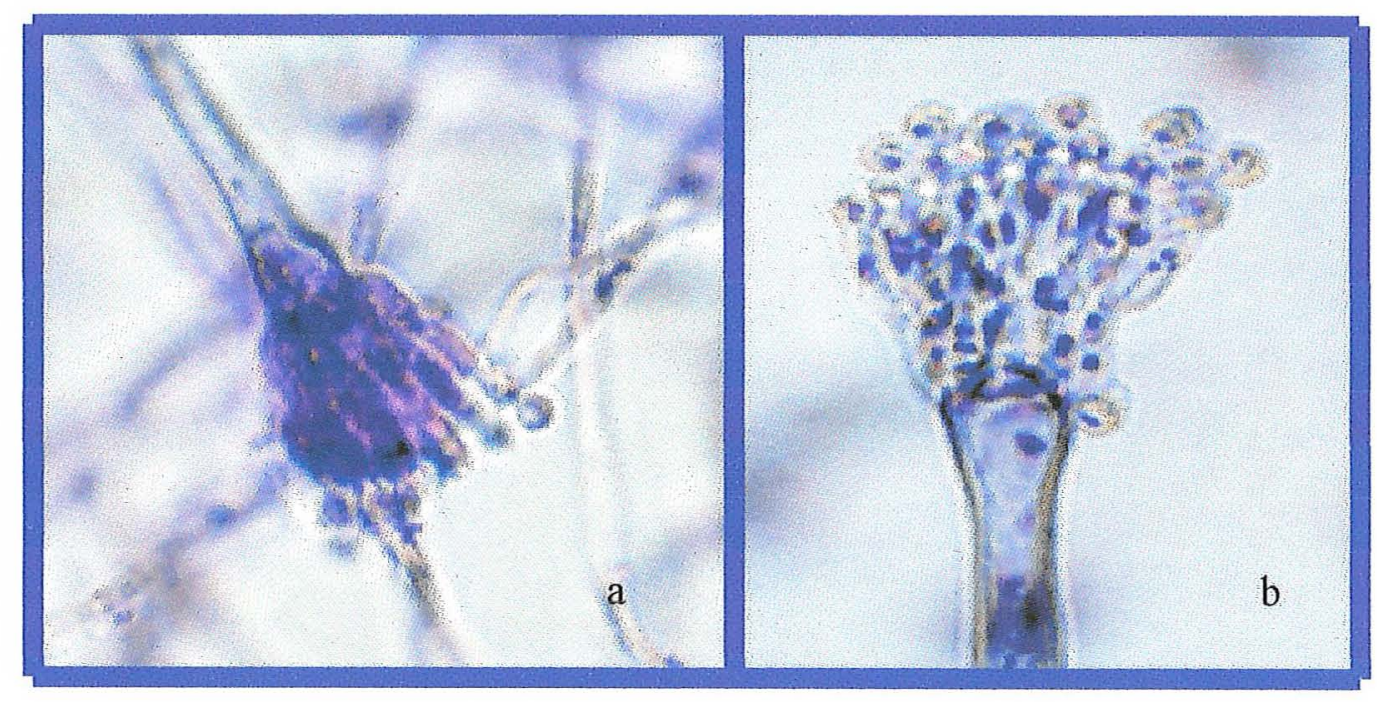

Figura 5. Micrografias de microscopia ótica da linhagem VB7 após coloração de Giemsa $\mathrm{HCl}$; a b. conidióforo com 38 e 54 horas respectivamente. Aumento $1.000 \mathrm{x}$. 


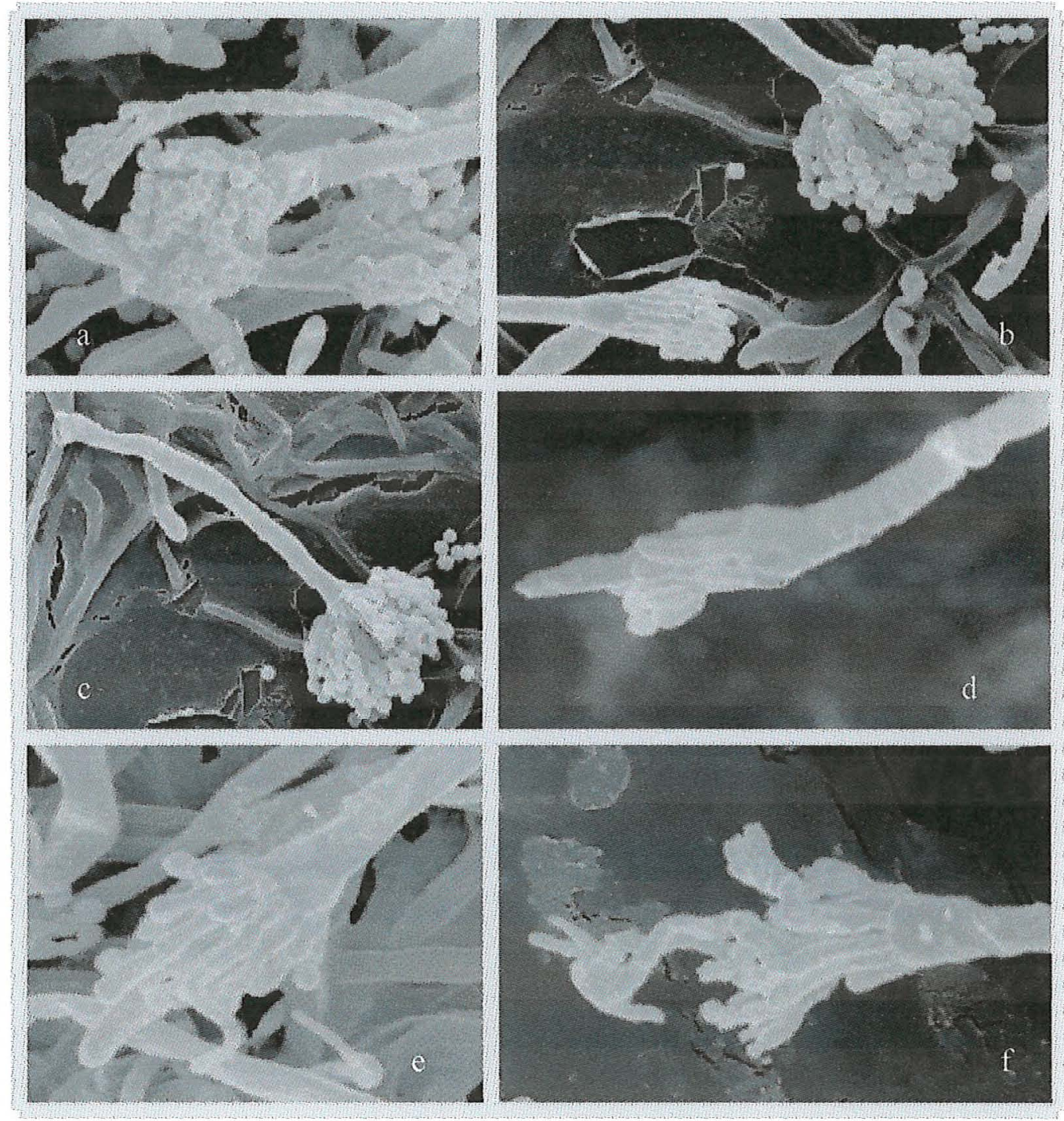

Figura 6. Micrografias de Microscopia Eletrônica de Varredura da linhagem VB7. a. conidióforo com desorganização temporal e espacial, aumento 3350 vezes; b. conidióforo com formação anormal de esterígmas, aumento 2970 vezes; c. conidióforo normal, aumento 2500 vezes; d, e conidióforos com anormalidades características dos Variantes Deteriorados, aumento 5030 e 4620 vezes respectivamente; f. conidióforo anormal, com formação de novos conidióforos a partir da métula, aumento 4500 vezes. 


\subsubsection{Análise Citológica do VB 8}

Esse variante deteriorado apresentou desorganização espacial e temporal das estruturas que compõem o conidióforo mais marcante quando comparado com VB7.

A diferenciação de hifas, seguindo com a formação de vesículas foi, observada a partir de 28 horas de desenvolvimento, além de ocorrer um atraso na formação de métulas e fiálides (Figura 7). Ocorre desorganização espacial característica, com o alongamento e indiferenciação de métulas. Algumas vesículas apresentam irregularidades no seu formato (Figura 8).

O VB8 apresentou uma quantidade muita baixa de conidióforos quando comparado com VB7. Esse deteriorado apresenta um número extremamente alto de células de Hülle.

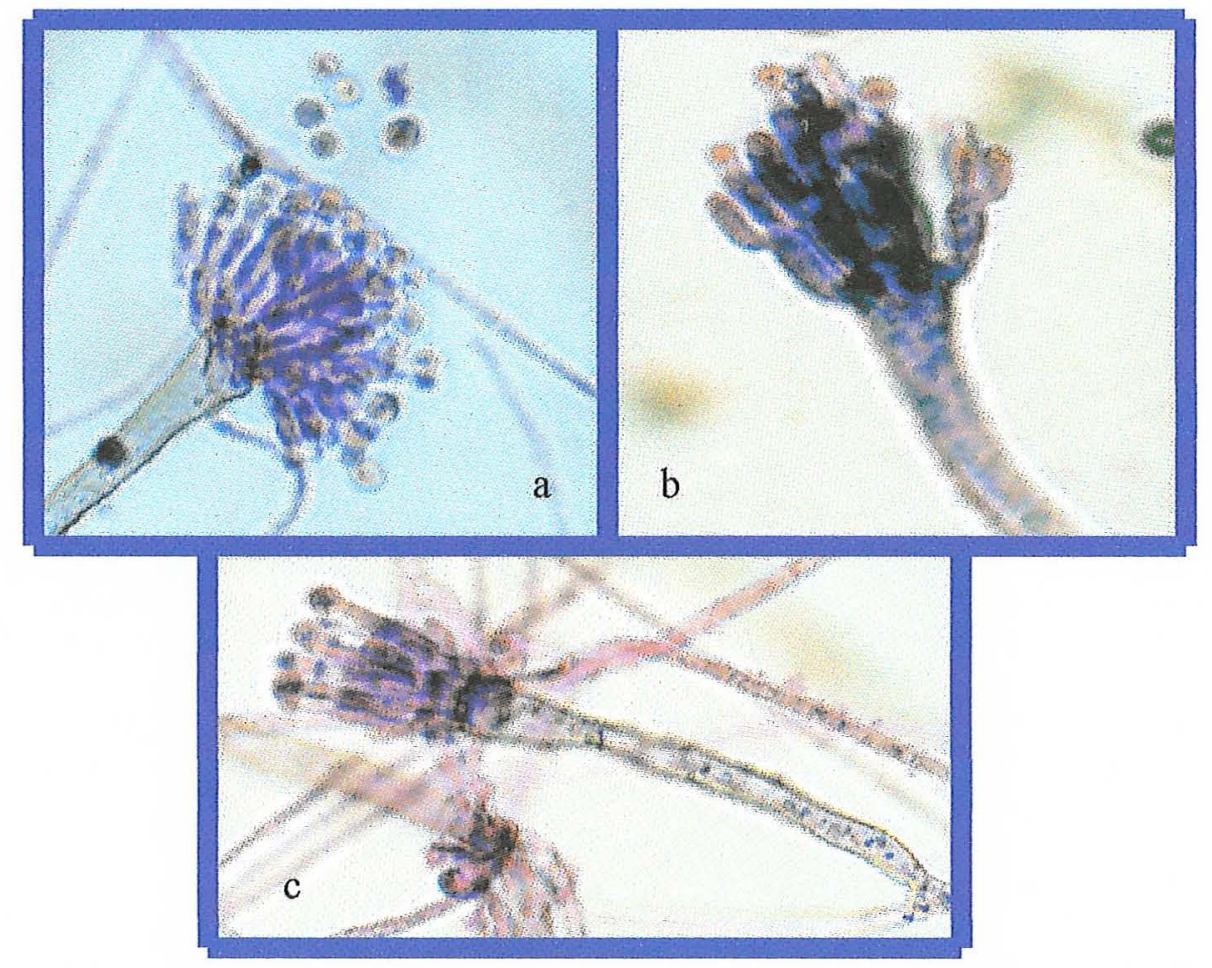

Figura 7. Micrografias de microscopia ótica da linhagem VB8 após coloração de Giemsa - $\mathrm{HCl}$, a. conidióforo com desarranjo de esterígmas, 34 horas; b. conidióforo com número reduzido de métulas, 56 horas; c. conidióforo com desenvolvimento alongado de métulas, 42 horas. Aumento de $1.000 \mathrm{x}$ 


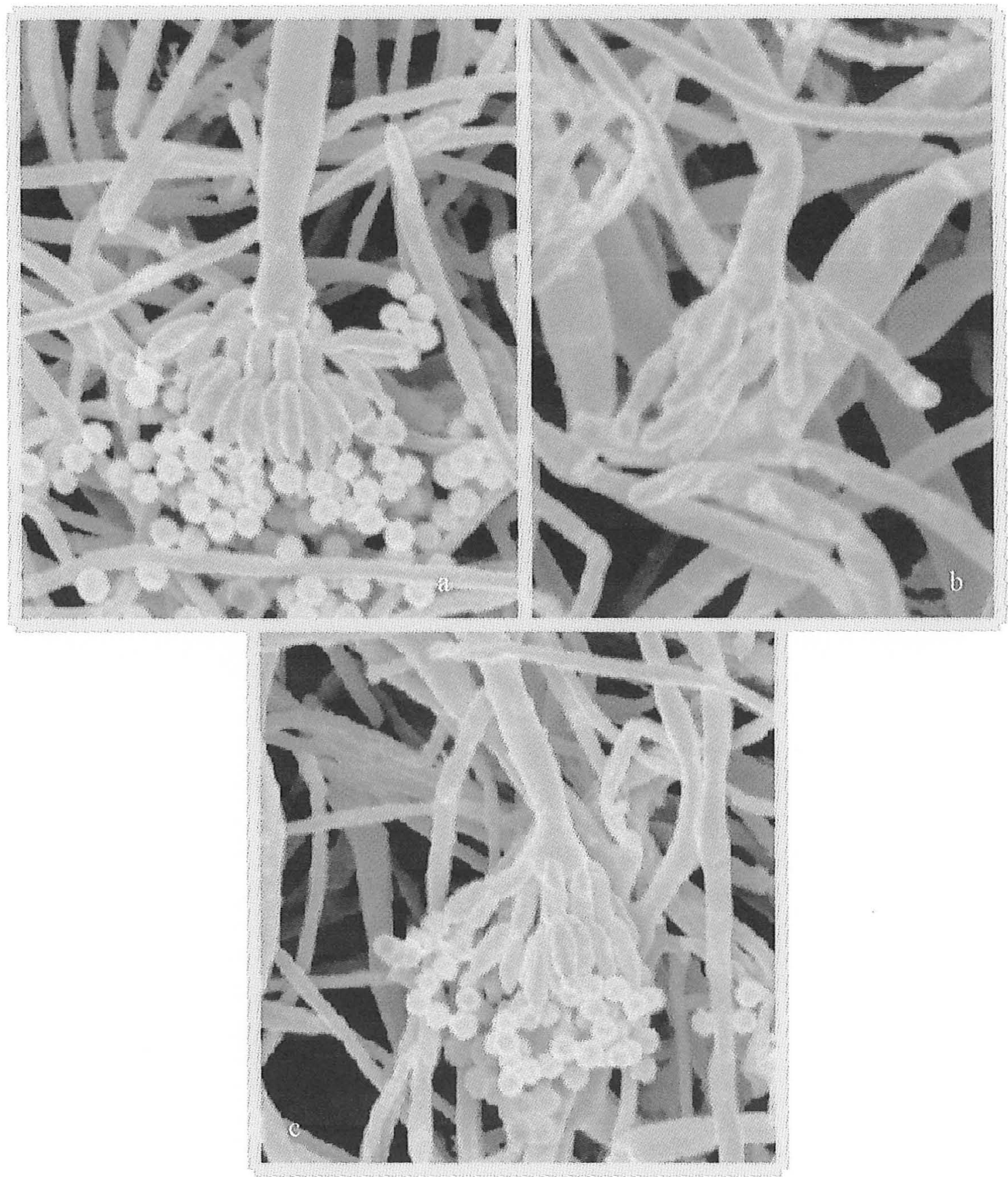

Figura 8 Micrografias de Microscopia Eletrônica de Varredura da linhagem VB8. a, b, c, conidióforo anormal, apresentando menor quantidade e desorganização dos esterígmas, aumento $3630,4030,3020$ vezes respectivamente. 


\subsubsection{Análise Citológica do VB 9.}

Esse variante deteriorado apresentou muita semelhança ao VB7.

O período de desenvolvimento temporal é semelhante aos estabelecidos para as linhagens padrões, onde, a partir de 20 horas de desenvolvimento é, possível observar vesículas com algumas métulas.

A quantidade de esporos observada nos conidióforos é menor quando comparada com o VB 7.

Por carregar a mutação no gene bncAl apresenta fiálides septadas e menor quantidade de métulas e fiálides (Figuras 9 e 10). Foram observados conidióforos normais (Figura $10 \mathrm{c}$ ).

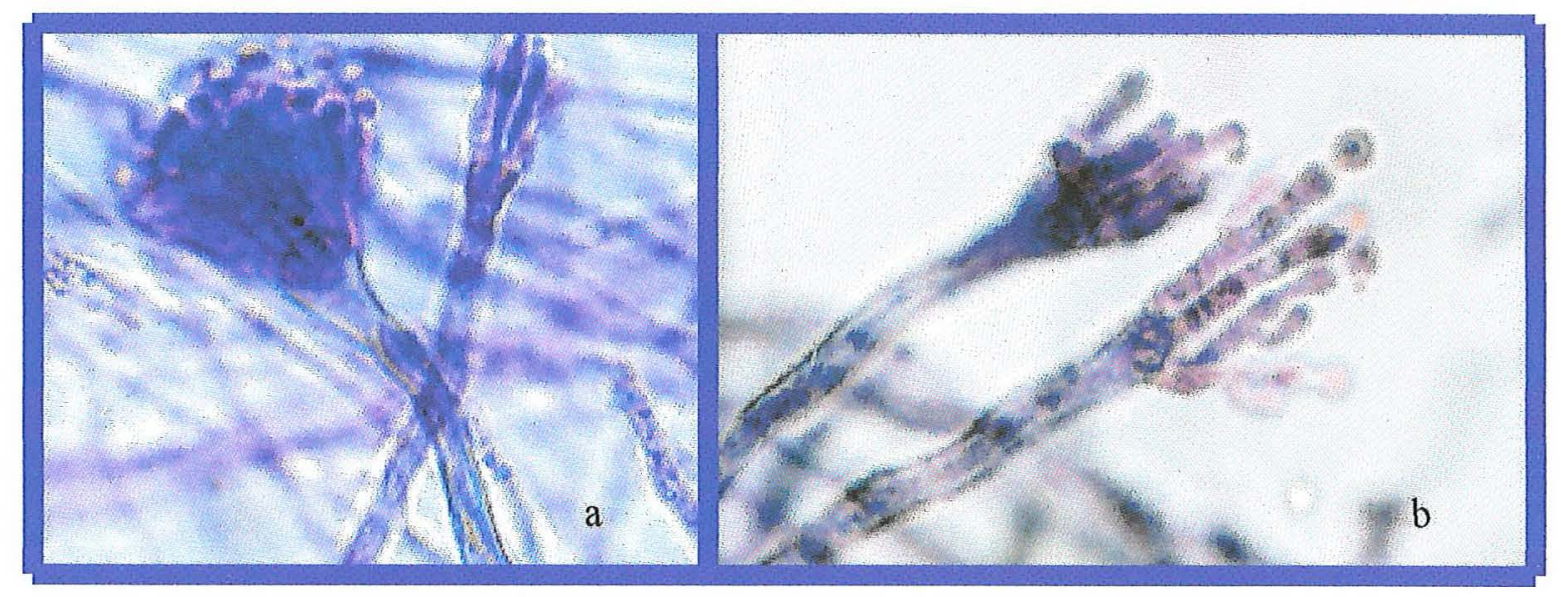

Figura 9. Micrografias de microscopia ótica da linhagem VB9 após coloração de Giemsa $\mathrm{HCl}$, a. b conidióforos com elongação de métulas 42 horas. Aumento de 1.000x. 


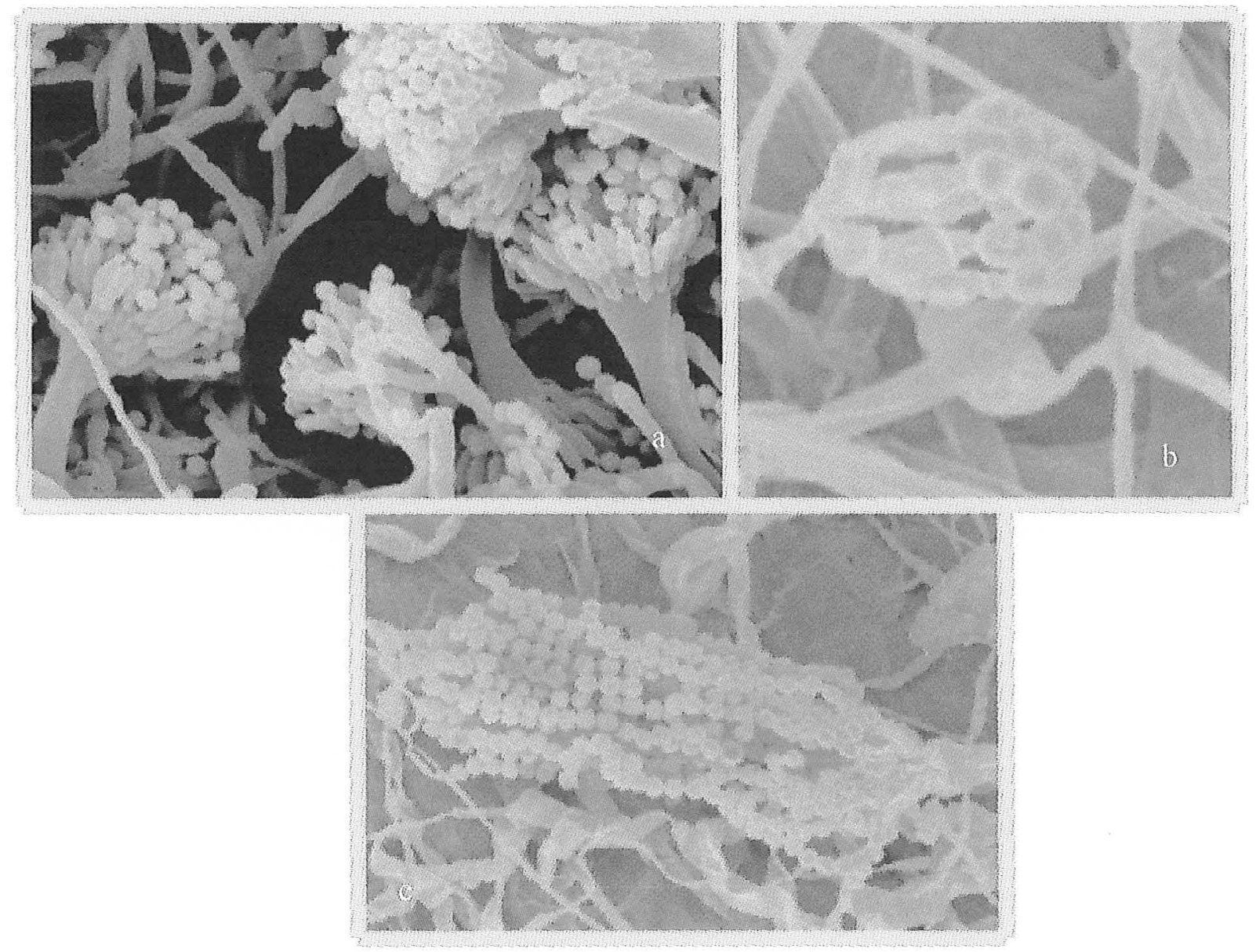

Figura 10. Micrografias de Microscopia Eletrônica de Varredura da linhagem VB9. a, b conidióforos com desorganização dos esterígmas, aumentos 3580 e 4650 vezes respectivamente; c. conidióforo normal com longas cadeias de conídios, aumento 2970 vezes. 


\subsubsection{Análise Citológica do VB 10 e VB11}

Esses dois variantes deteriorados apresentaram um atraso maior no processo de desenvolvimento temporal - espacial do conidióforo em relação aos outros deteriorados analisados (Figuras 12 e 14).

O início da diferenciação das hifas ocorreu por volta de $30-34$ horas. A quantidade de conidióforos observados também é extremamente reduzida, sendo que em alguns casos, em preparações com membrana de diálise ou lamínula não foi possível observar os conidióforos. (Figuras 11, 12, 13 e 14).

Análise dos conidióforos demonstrou um atraso no desenvolvimento temporal - espacial muito marcante, sendo observado que em alguns conidióforos enquanto uma fiálide apresentava conídios maduros, outras estavam em formação. Observou-se uma quantidade superior de métulas e fiálides indiferenciadas, além das fiálides apresentam-se septadas, devido à presença do gene bncA1.

A característica marcante dessas duas linhagens consiste de uma grande quantidade de métulas indiferenciadas, com alongamento, e pouquíssima quantidade de esporos.

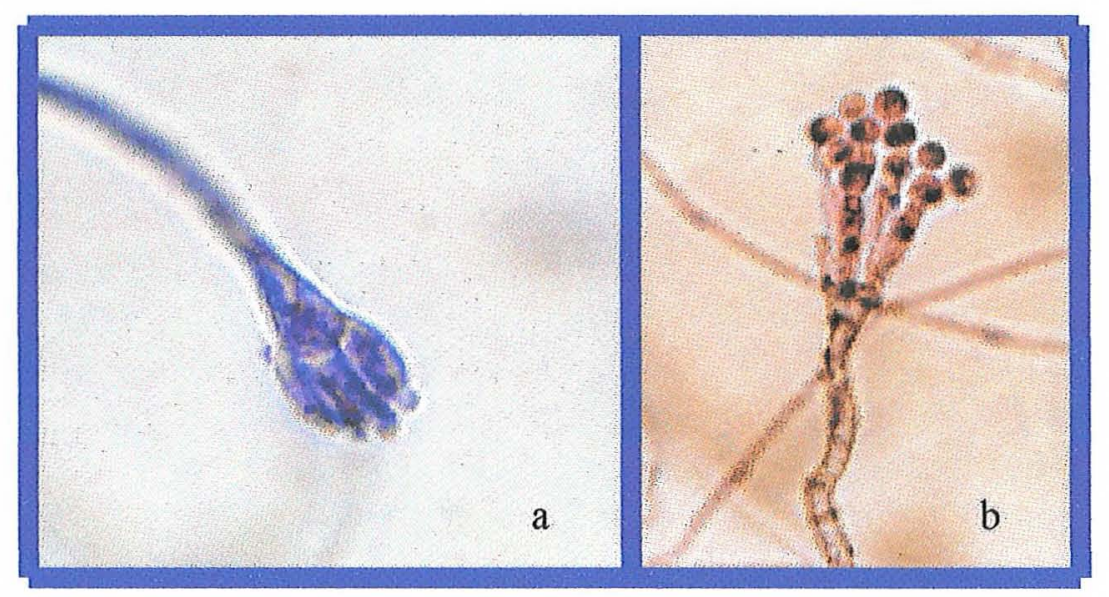

Figura 11. Micrografias de microscopia ótica da linhagem VB 10 após coloração de Giemsa - $\mathrm{HCl}$; a conidióforo com início do desenvolvimento de métulas, 32 horas; b. conidióforo com métulas alongadas e indiferenciadas, 64 horas, Aumento de $1.000 \mathrm{x}$ 


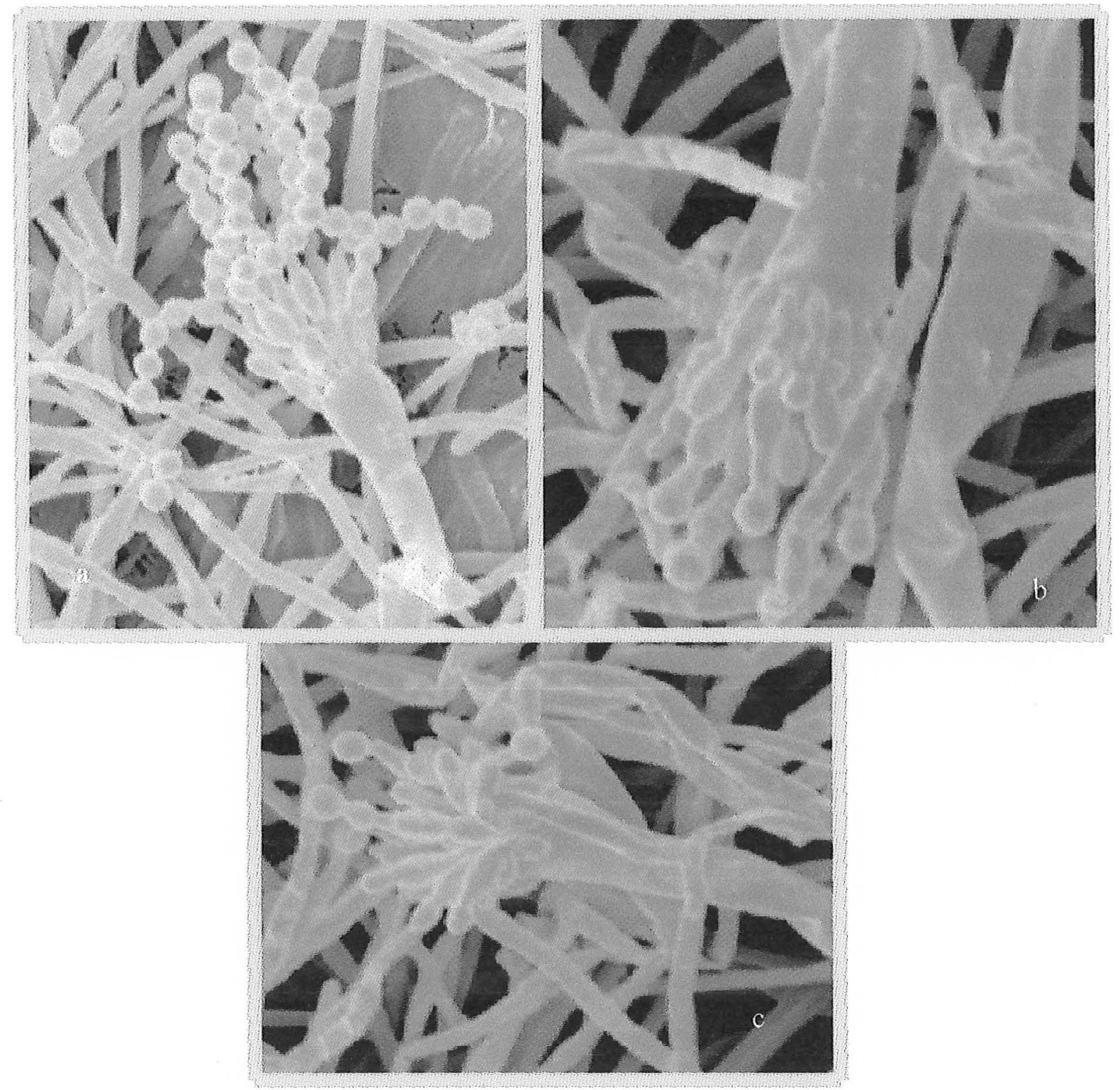

Figura 12. Micrografias de Microscopia Eletrônica de Varredura da linhagem VB 10. a, b, c conidióforos com desenvolvimento anormal, aumentos 3190, 3870 e 3320 vezes, respectivamente. 


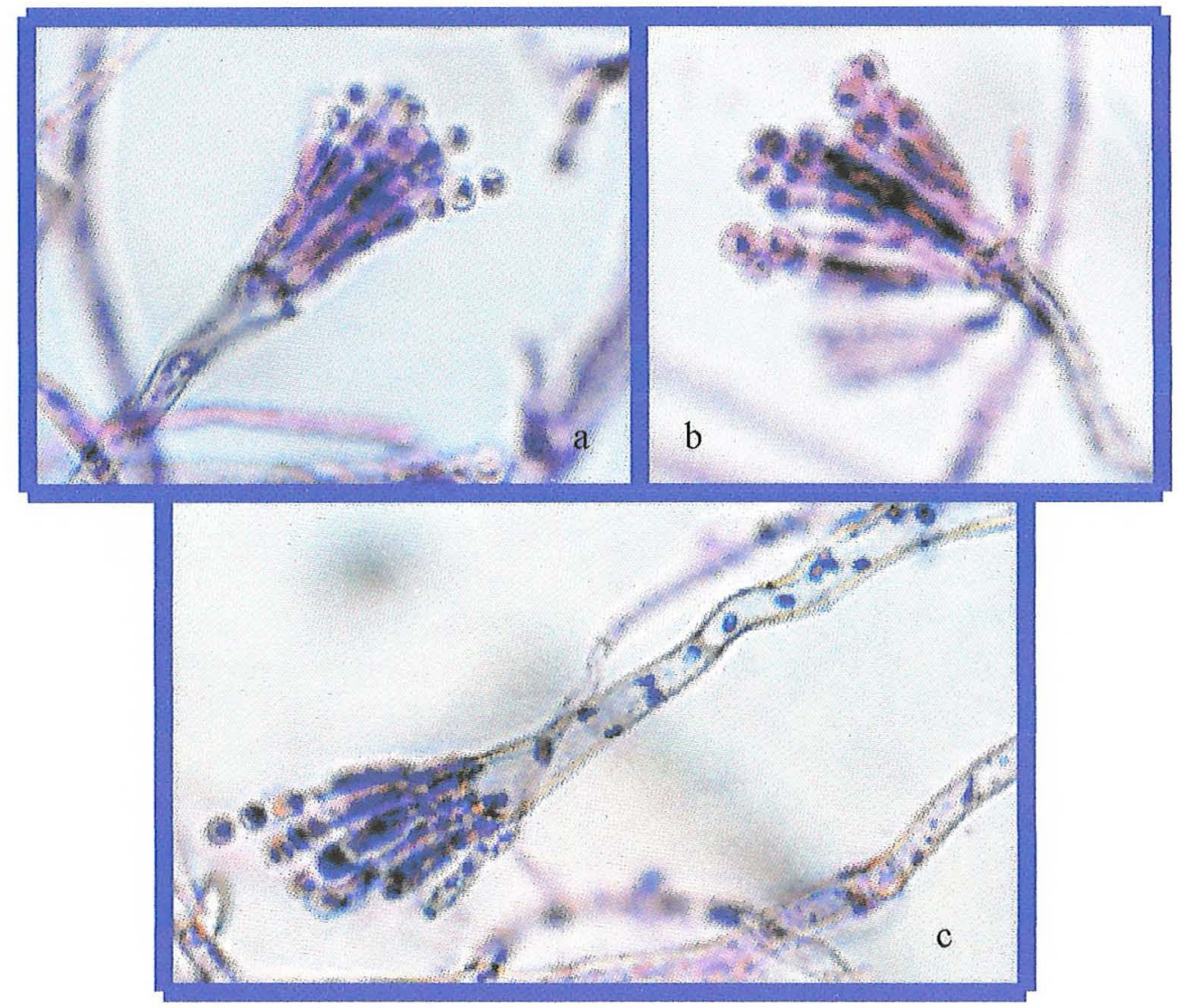

Figura 13. Micrografias de microscopia ótica da linhagem VB 11 após coloração de Giemsa-HCl; a. a, b, c. conidióforos com métulas alongadas e indiferenciadas, 34, 64 e 42 horas respectivamente. Aumento de $1.000 \mathrm{x}$. 


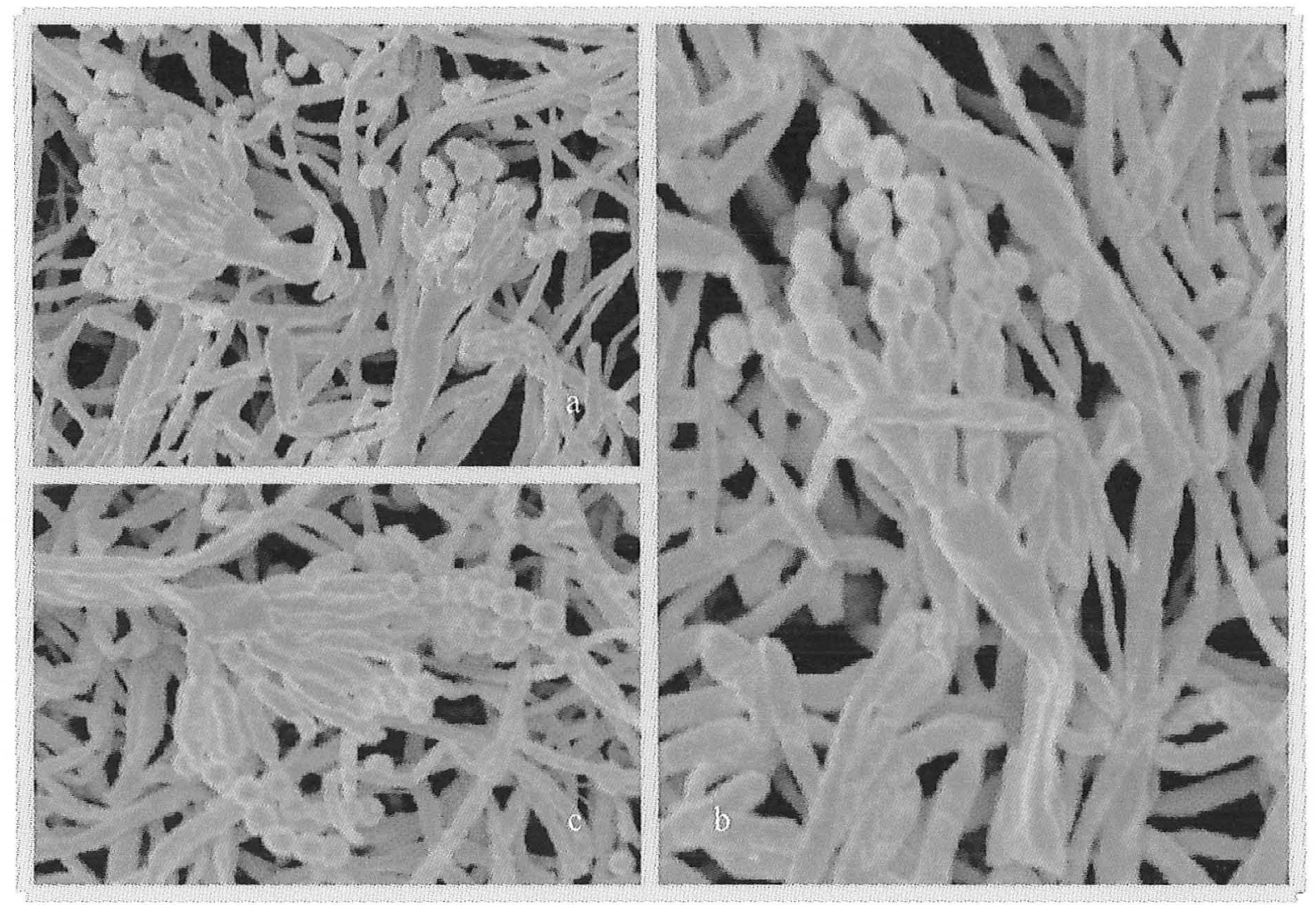

Figura 14. Micrografias de Microscopia Eletrônica de Varredura da linhagem VB 11. a, b, c, conidióforos com desenvolvimento anormal, aumentos 2750, 3110, 3370 vezes, respectivamente. 


\subsubsection{Análise Citológica do V 101 e V 102}

Esses dois Variantes deteriorados, originários da linhagem $\mathrm{A}$ de $A$. nidulans, foram analisados conjuntamente devido às semelhanças que apresentaram.

O desenvolvimento temporal e espacial de V101 e V102 foi semelhante ao das linhagens padrões analisadas (Figuras 15 e 16).

Em relação à desorganização espacial e temporal das estruturas de desenvolvimento do ciclo assexual que essas duas linhagens apresentam, observou-se uma grande semelhança com as outras linhagens de variantes deteriorados originárias da linhagem Abnc de $A$. nidulans, analisadas anteriormente, que consistem de menor número de métulas, que são indiferenciadas (estruturas alongadas) (Figuras 15, 16, 17, 18). Não se observou septação de métulas ou fiálides.

Comparando os variantes deteriorados já analisados, observou-se que esses dois deteriorados possuem uma maior quantidade de conidióforos sendo, que muitos possuem conidióforo com morfologia normal, com longas cadeias de conídios. Essas duas linhagens apresentaram um número muito alto de células de Hülle. 


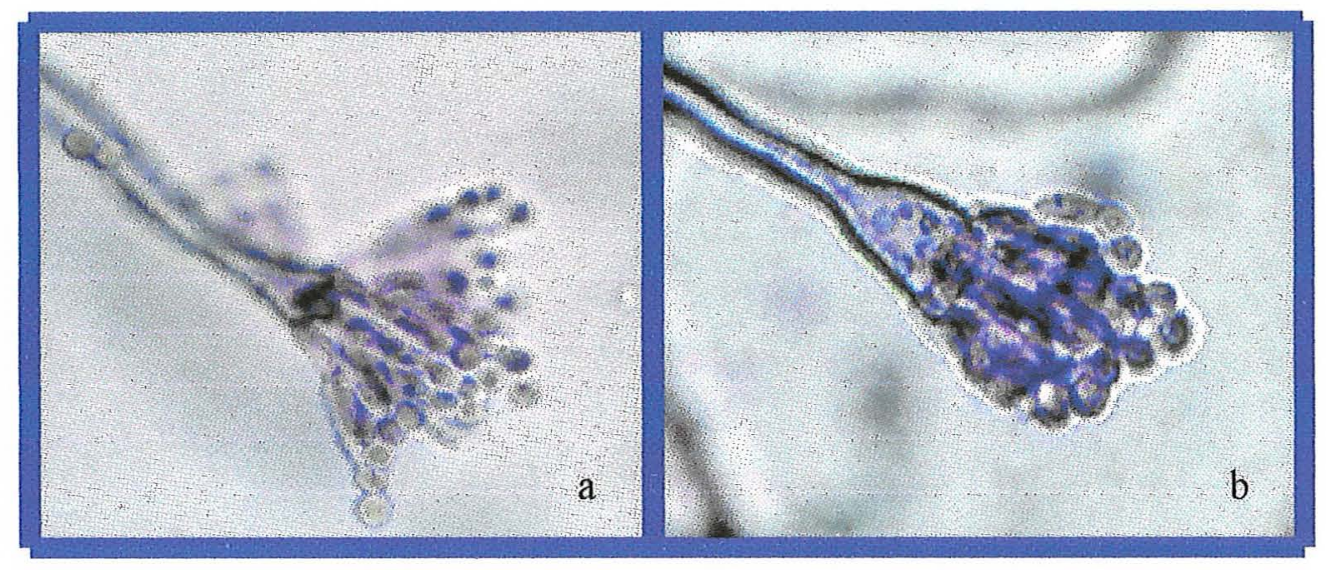

Figura 15. Micrografias de microscopia ótica da linhagem V 101 após coloração de Giemsa - $\mathrm{HCl}$, a, b. conidióforos com desorganização de esterígmas, 34 e 38 horas respectivamente. Aumento de $1.000 \mathrm{x}$

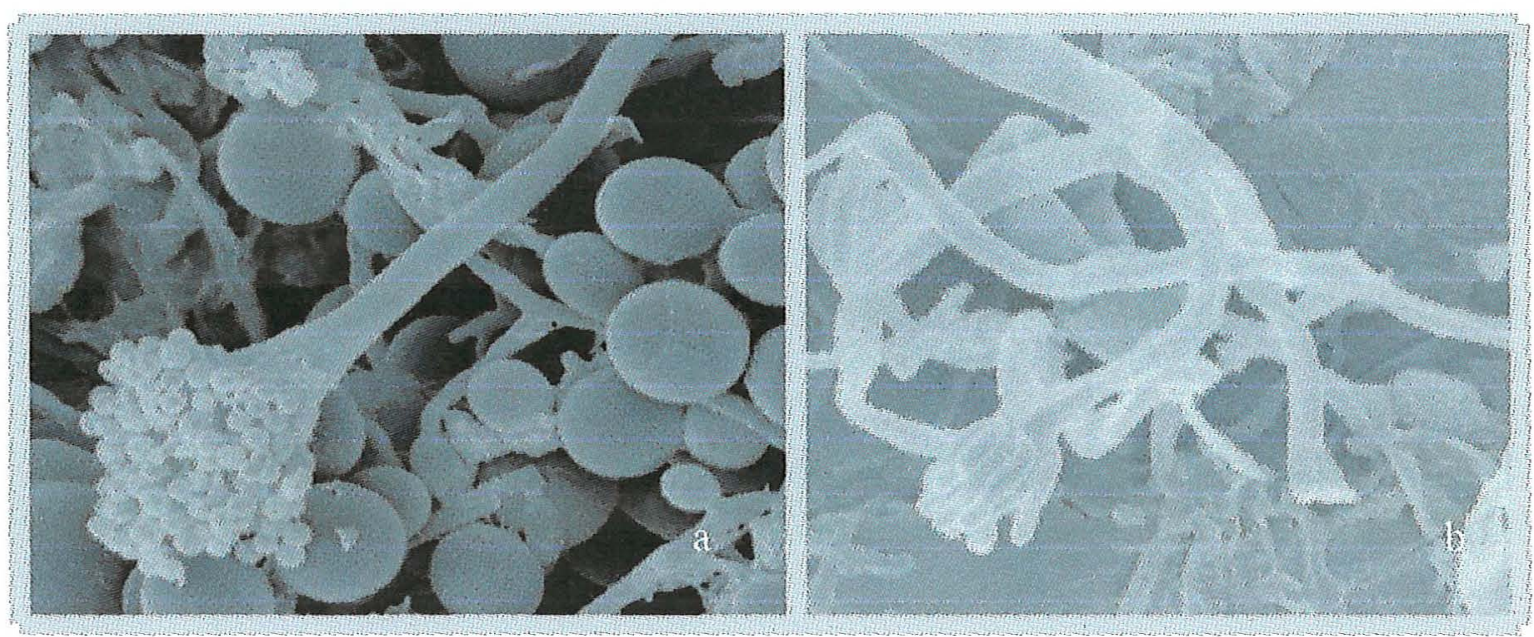

Figura 16. Micrografias de Microscopia Eletrônica de Varredura da linhagem V 101.a conidióforo normal com células de Hülle, aumento 2630, b. conidióforo com desorganização e esterígmas, aumento 3730 vezes. 


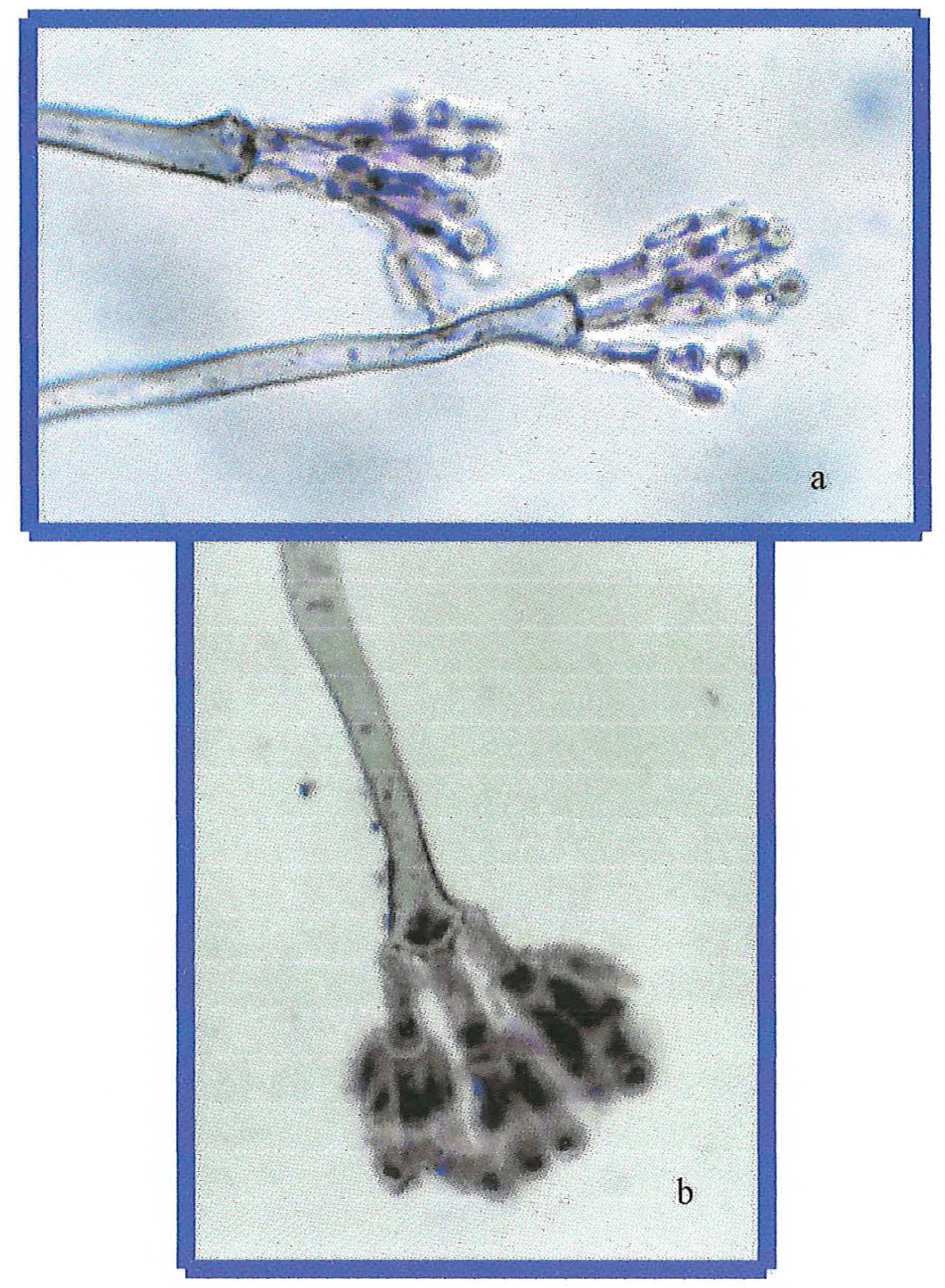

Figura 17 Micrografias de microscopia ótica da linhagem V 102 após coloração de Giemsa - $\mathrm{HCl} ; \mathrm{a}, \mathrm{b}$. conidióforo com número reduzido, desorganização e indiferenciação dos esterígmas, 34 e 64 horas respectivamente. Aumento de 1.000 x 


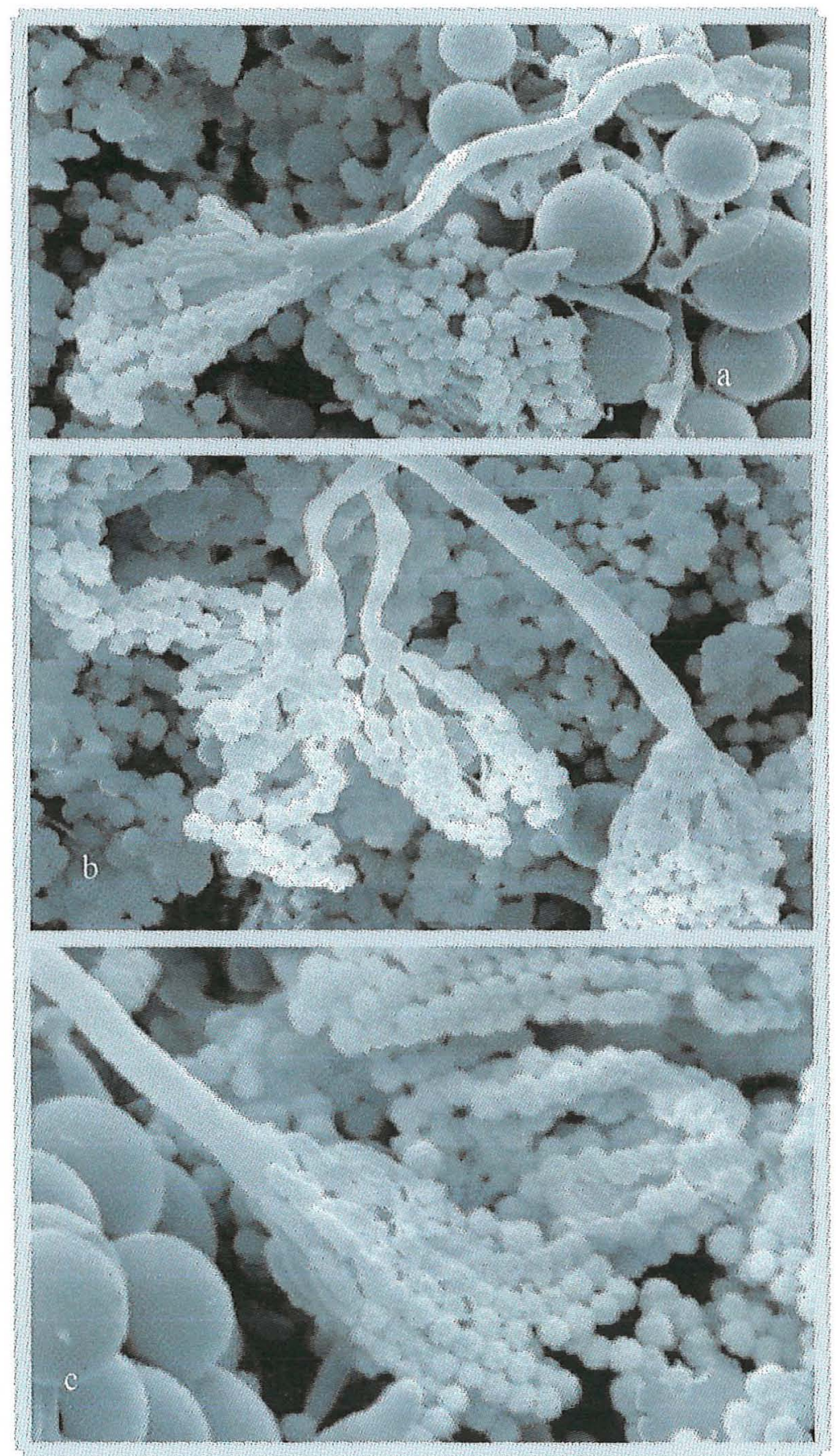

Figura 18. Micrografias de Microscopia Eletrônica de Varredura da linhagem V 102. a, b, c conidióforos com desenvolvimento anormal dos esterígmas, aumento 3570, 2990 e 3340 vezes respectivamente. 


\subsubsection{Análise Citológica do V 103}

Esse variante deteriorado originário da linhagem $\mathrm{A}$, apresentou desenvolvimento temporal semelhante às linhagens padrões analisadas, além de uma grande quantidade de conidióforos sem desorganização de suas estruturas, ao mesmo tempo os conidióforos anormais. As anormalidades observadas nesse deteriorado foram as mais interessantes (Figuras 19, 20 e 21).

Os conidióforos com desenvolvimento anormal das estruturas de reprodução do ciclo assexual apresentavam métulas alongados indiferenciadas, como observado nos outros variantes deteriorados (Figuras $21 \mathrm{c}, \mathrm{d}$ ).

Foram observados conidióforos com morfologia semelhante aos mutantes do grupo "bristle" (Figura 24 c, d), onde a partir da métula ocorre uma diferenciação de um novo conidióforo.

Alguns conidióforos apresentaram desenvolvimento anormal da haste. Essa estrutura apresentou-se mais alongada que o normal e ramificada, dando origem a dois conidióforos completos, mas que apresentam uma menor quantidade de métulas, quando comparados com as linhagens padrões (Figuras $20 \mathrm{a}, \mathrm{b}$ ).

Nessa linhagem, também foi observada uma enorme quantidade de células de Hülle, sendo a única linhagem que apresentou cleistotécios (Figura 21 b). 


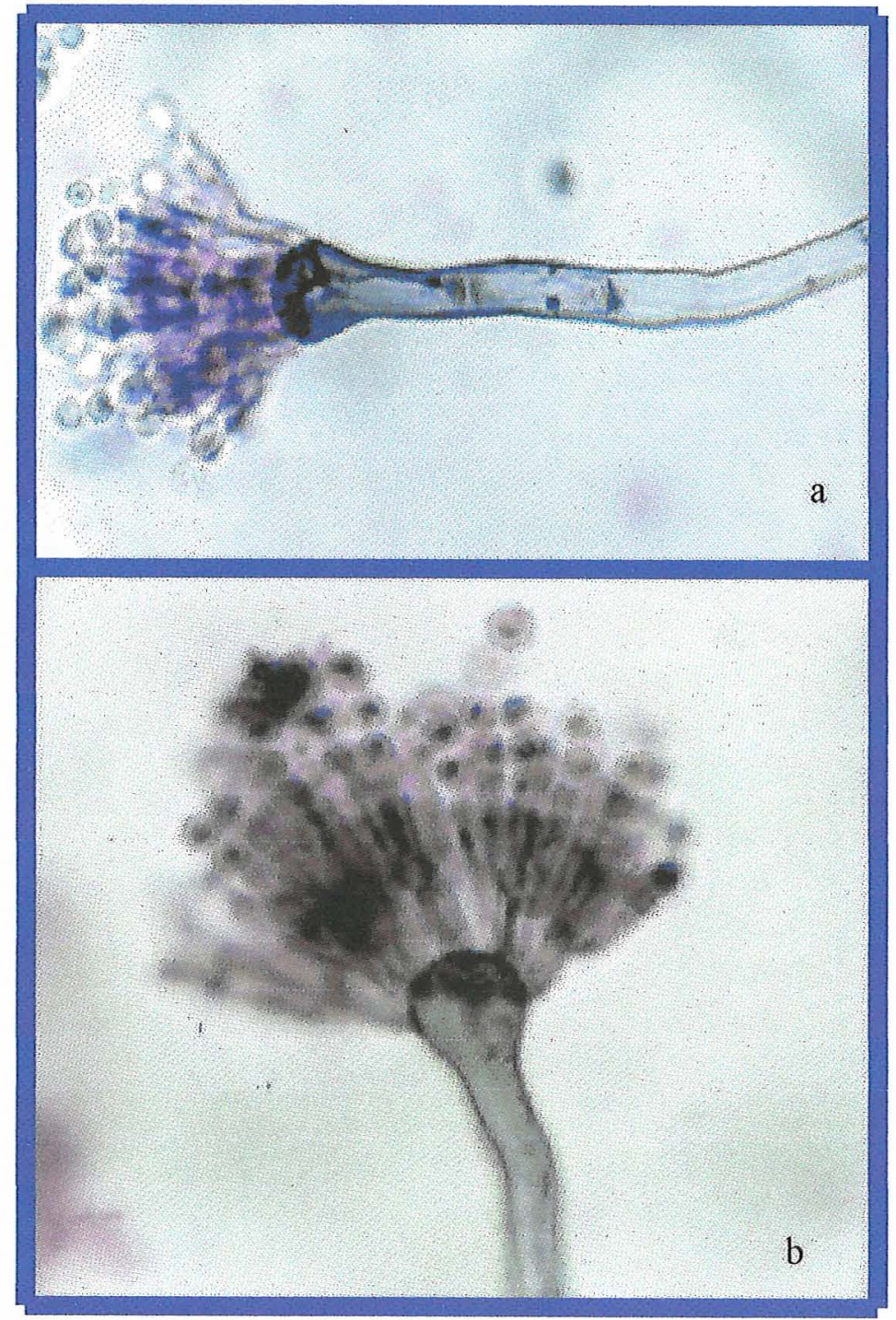

Figura 19. Micrografias de microscopia ótica da linhagem V 103 após coloração de Giemsa-HCl; a conidióforos indiferenciados 54 horas. Aumento de $1.000 \mathrm{x}$ 


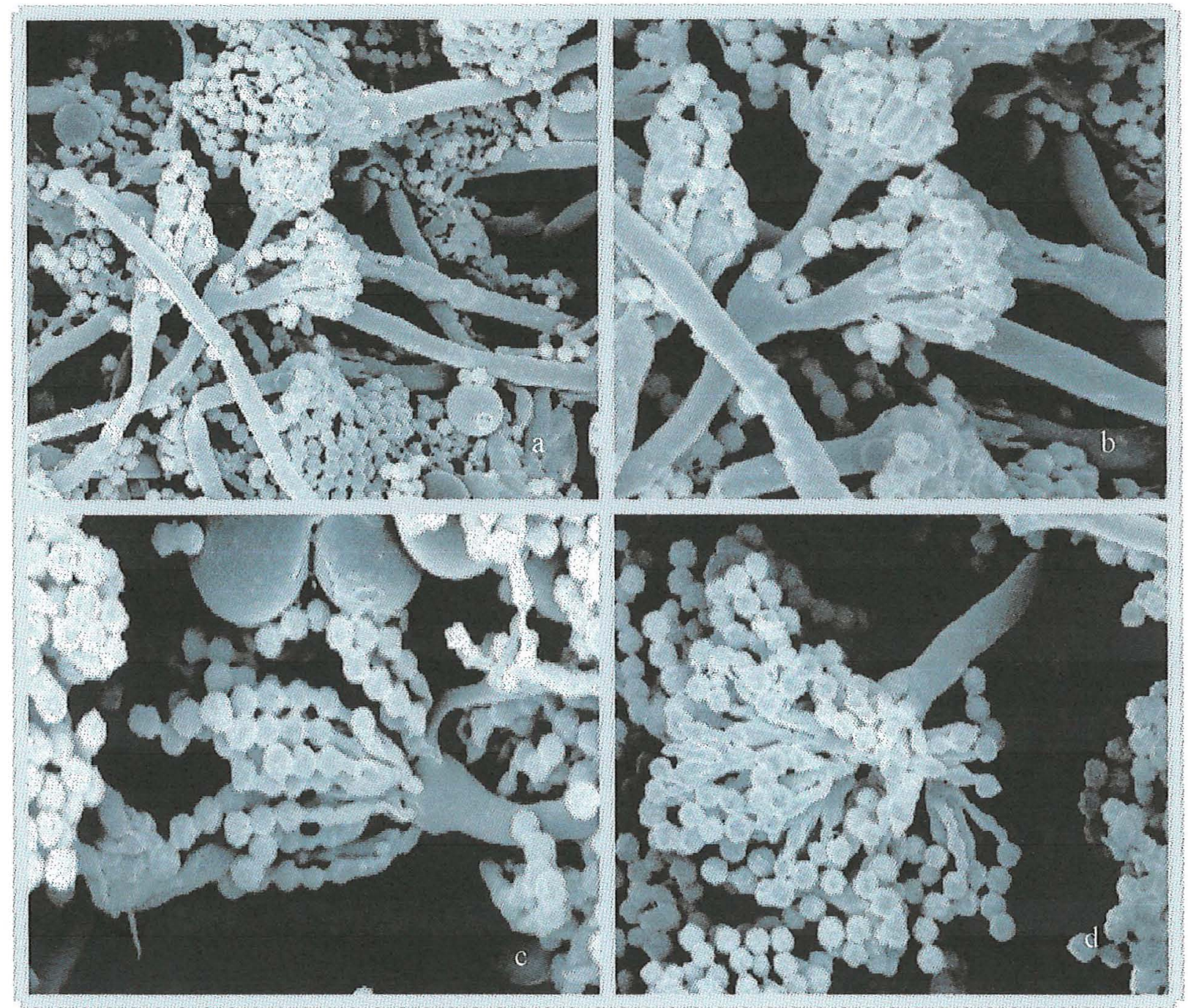

Figura 20. Micrografias de Microscopia Eletrônica de Varredura da linhagem V 103. a, b conidióforo com haste ramificada, aumentos 1870 e 3490 respectivamente; c, d conidióforos com desenvolvimento normal, aumentos 3360 e 3300 respectivamente. 


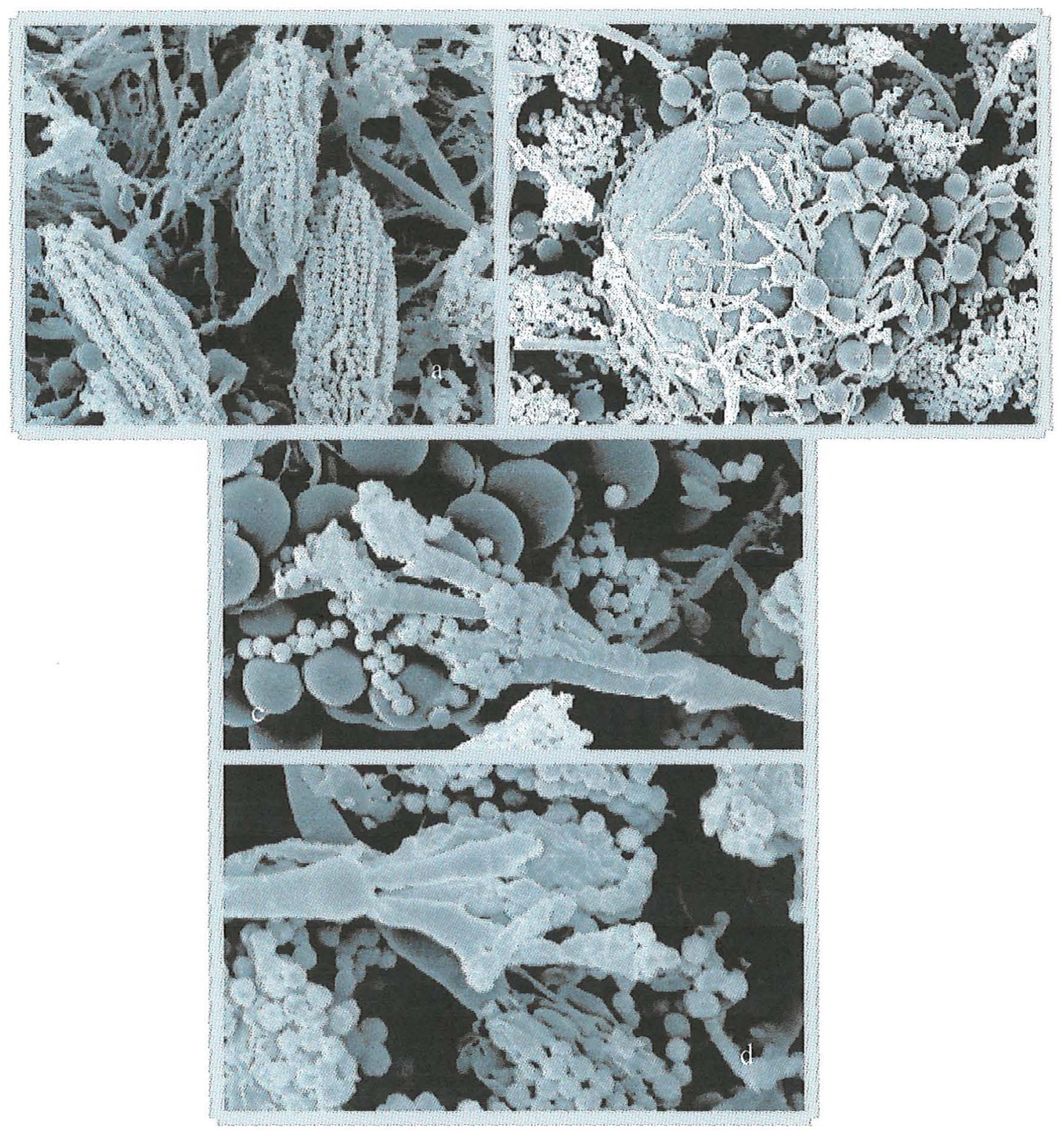

Figura 21. Micrografias de Microscopia Eletrônica de Varredura da linhagem V 103. a. conidióforo normal, aumentos 1460; b, células de Hülle envolvendo cleistotécios, aumento 1330; c, d conidióforos com desenvolvimento anormal, com formação de novos conidióforos a partir das métulas, aumentos 3030 e 3420 respectivamente. 


\subsubsection{Análise Citológica do V 104}

Essa linhagem apresentou menor quantidade de conidióforos, quando comparados a outros variantes deteriorados. A desorganização do conidióforo foi muito semelhante ao dos outros variantes deteriorados analisados (Figuras 22 e 23)

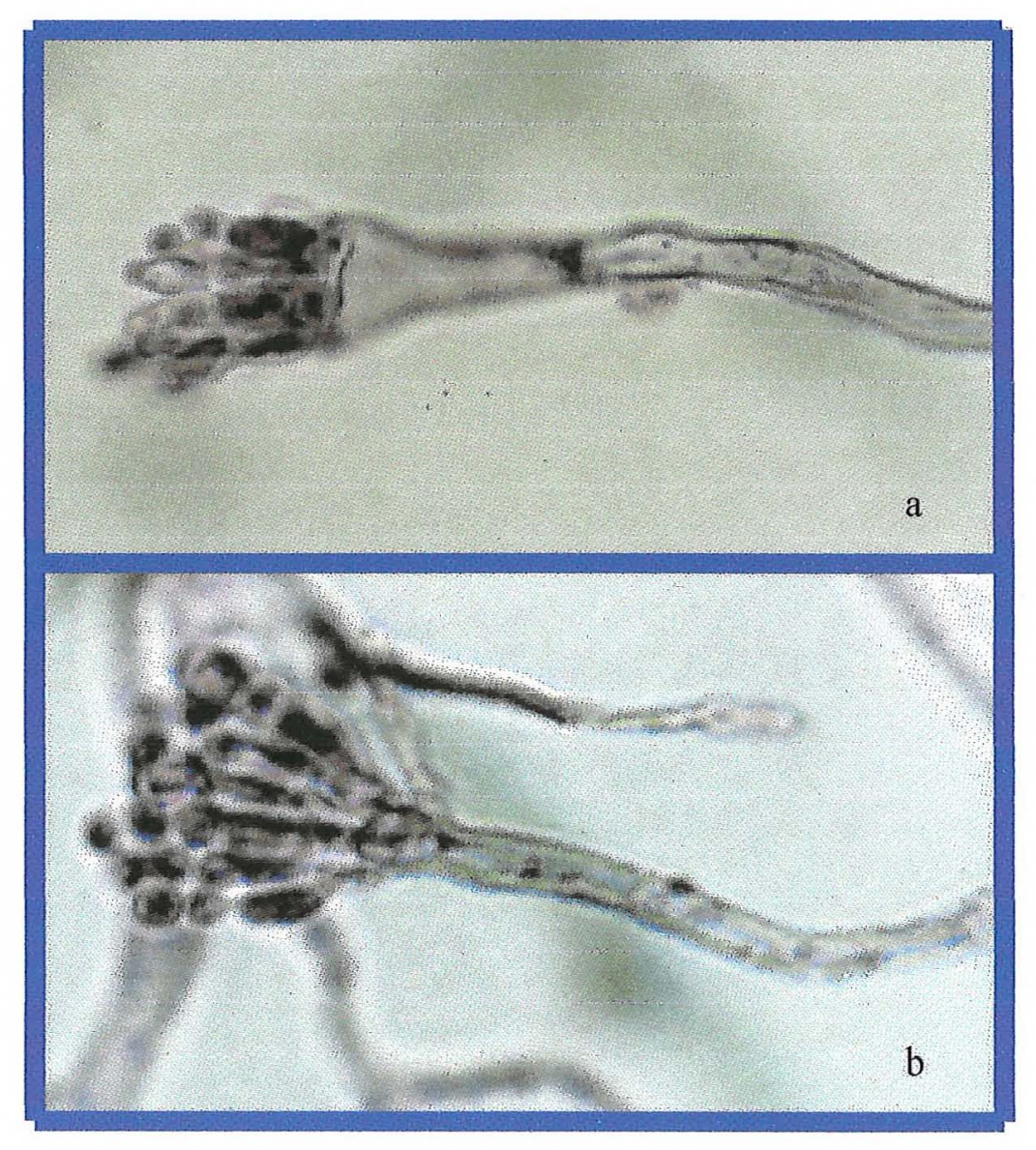

Figura 22. Micrografias de microscopia ótica da linhagem V 104 após coloração de Giemsa - HC; a, b. conidióforos com desorganização de esterígmas, 64 e 32 horas respectivamente. Aumento de 1.000 vezes. 


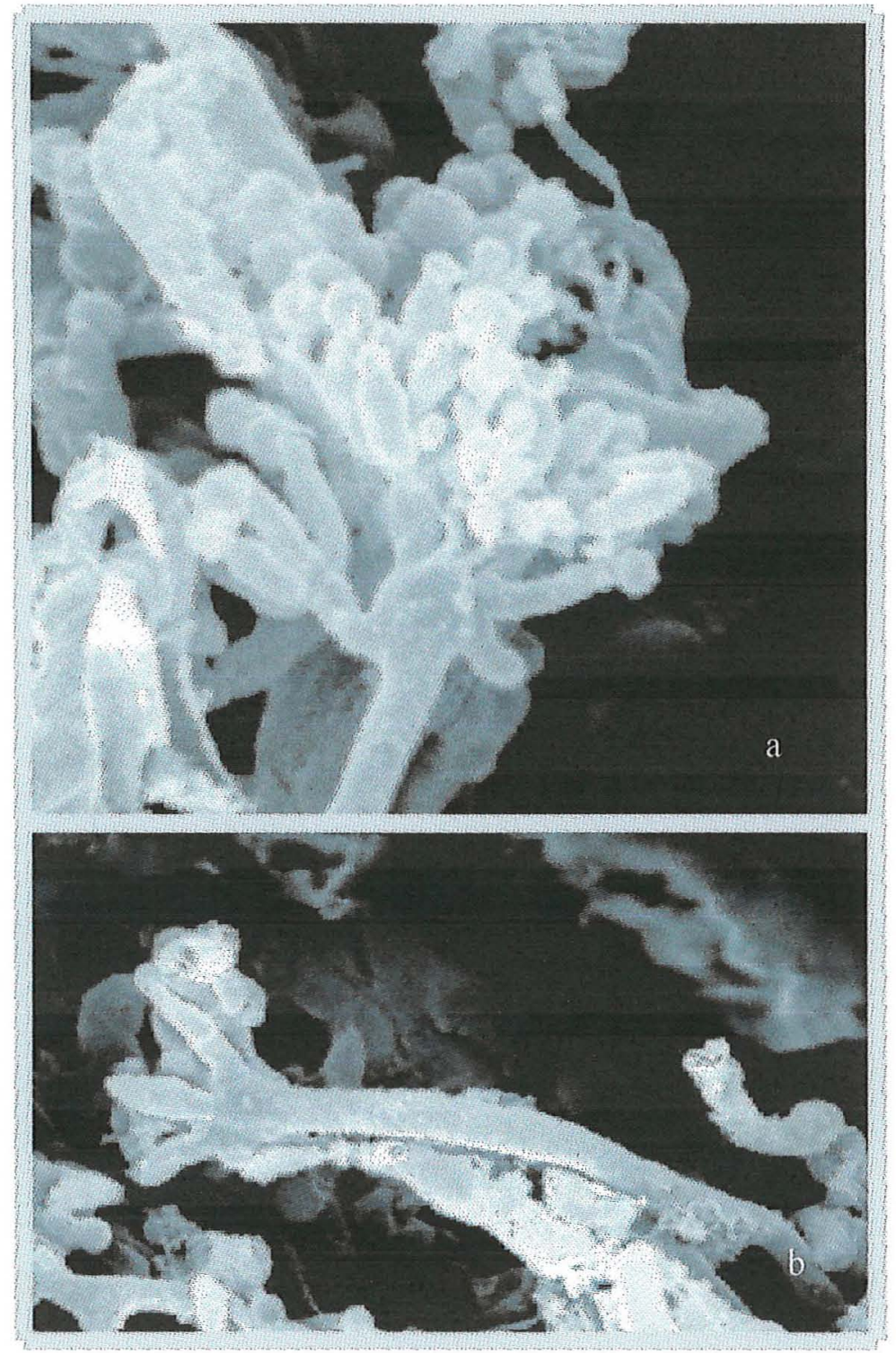

Figura 23. Micrografias de Microscopia Eletrônica de Varredura da linhagem V 104. a, b conidióforo com desenvolvimento anormal dos esterígmas, aumentos 4970 e 2600 respectivamente. 
4.3.9. Comparação das Análises Citológicas entre os Variantes Deteriorados provenientes das linhagens A e Abnc.

A comparação entre os variantes deteriorados originários das linhagens $\mathrm{A}$ e Abnc de $A$. nidulans, foi realizada para verificar a existência de diferenças na organização espacial e temporal das estruturas reprodutivas do ciclo assexual.

Os variantes deteriorados originários da linhagem Abnc foram designados como: VB 7, VB 8, VB 9, VB 10 e VB 11, seguindo classificação iniciada por Pascon (1994). Em relação ao desenvolvimento temporal das estruturas de reprodução do ciclo assexual, esses variantes deteriorados apresentam semelhanças quando comparados às linhagens padrões, com o desenvolvimento inicial do conidióforo, em torno de 20 horas, com atraso no desenvolvimento das linhagens VB 8, VB 10 e VB 11. Esses cinco deteriorados também apresentaram desorganização espacial característica, sendo observada por Pascon (1994) nas linhagens portadoras da mutação bnc $\mathrm{A}_{1}$. As desorganizações espaciais consistem de formação de conídios bi e trinucleados, desarranjo estrutural com diminuição das métulas dos conidióforos, além de ocorrer uma diminuição na quantidade de conídios formados pelo conidióforo.

Os variantes deteriorados originários da linhagem A foram designados como: V 101, V 102, V103 e V104, seguindo classificação de Azevedo e Roper (1970). Durante a análise da conidiogênese desses variantes deteriorados, observou-se que o desenvolvimento temporal e espacial das estruturas de reprodução do ciclo assexual, é semelhante ao desenvolvimento das linhagens padrões, seguindo o período de tempo estabelecido para o desenvolvimento de cada estrutura que compõe o conidióforo. Os variantes deteriorados V 101, V 102 e V 103 apresentam uma quantidade superior de conidióforos quando comparados como os outros variantes deteriorados originários da linhagem Abnc, incluindo uma quantidade menor de conidióforos anormais, apenas o variante deteriorado V 104 apresentou uma baixíssima quantidade de conidióforos Todos os variantes deteriorados originários da linhagem $\mathrm{A}$ apresentaram uma altíssima quantidade 
de células de Hülle (quantidade maior que as observadas nos variantes deteriorados originários da linhagem $\mathrm{Abnc}$ ).

O V 103 foi o único variante deteriorado que apresentou corpo de frutificação do ciclo sexual, o cleistotécio. Esse variante deteriorado apresentou uma alteração morfológica intrigante, sendo que a haste do conidióforo se diferencia e alonga e sofre uma ramificação, dando origem a duas novas hastes que alonga-se, dando origem a dois conidióforos completos.

\subsection{Análise Genética}

\subsubsection{Obtenção de heterocário}

Para a análise genética, foram utilizados os variantes deteriorados da linhagem Abnc sendo, submetidos ao cruzamento com a linhagem testadora MSE, que possui marcadores em todos os grupos de ligação. A formação da película heterocariótica foi relativamente fácil, mas sempre utilizou a concentração constante de $10^{7}$ conídios $/ \mathrm{mL}$ de cada linhagem testada. A membrana heterocariótica desenvolveu-se em meio mínimo acrescido de $2 \%$ de meio completo (item 3.2.7), após três dias de incubação a $37^{\circ} \mathrm{C}$.

Realizaram-se transferências das membrana heterocarióticas para meio mínimo sólido (item 3.2.1), sendo necessárias duas películas para cada cruzamento, uma para o ciclo parassexual que permaneceu incubada por 6 dias a $37^{\circ} \mathrm{C}$ e outra para o ciclo sexual, sendo a placa com a membrana vedada com fita adesiva e incubada por 12 dias a $37^{\circ} \mathrm{C}$.

\subsubsection{Isolamento de diplóide.}

Os diplóides provenientes do cruzamento parassexual foram obtidos após semeadura dos conídios retirados da membrana heterocariótica e semeados por 5 dias a $37^{\circ}$ C. 
Os diplóides isolados foram purificados, sendo selecionados apenas diplóides verdes. A confirmação se realmente eram colônias diplóides ocorreu de duas maneiras: a primeira pela capacidade das colônias diplóides de crescerem em meio mínimo através de susceptíveis repicagens, sendo possível já que as linhagens parentais possuem marcadores auxotróficos complementares; o segundo critério é a média do diâmetro dos conídios diplóides assim como a média do diâmetro dos núcleos diplóides das linhagens analisadas nos cruzamentos. Roper (1952), relacionou o tamanho entre conídios haplóides e diplóides, como 1:1,3.

Neste trabalho, utilizou-se o cruzamento MSE x bi meth como padrão, tanto para medição dos conídios e núcleos haplóides e diplóides.

$\mathrm{Na}$ tabela 13, é possível observar as médias do diâmetro dos conídios e núcleos diplóides após coloração Giemsa-HCl.

Tabela 13. Média e desvio padrão do diâmetro dos conídios e núcleos diplóides, obtidos nos cruzamentos, após coloração Giemsa-HCl.

\begin{tabular}{ccccc}
\hline \hline Cruzamentos & $\begin{array}{c}\text { Média dos conídios } \\
\text { diplóides (um) }\end{array}$ & $\begin{array}{c}\text { Desvio } \\
\text { padrão }\end{array}$ & $\begin{array}{c}\text { Média dos núcleos } \\
\text { diplóides (um) }\end{array}$ & $\begin{array}{c}\text { Desvio } \\
\text { padrão }\end{array}$ \\
\hline Bi meth // MSE & 4,06 & 0,16 & 1,86 & 0,09 \\
VB 7 // MSE & 4,17 & 0,15 & 1,62 & 0,14 \\
VB 8 // MSE & 4,14 & 0,14 & 1,55 & 0,13 \\
VB 9 // MSE & 4,10 & 0,17 & 1,64 & 0,13 \\
VB 10 // MSE & 4,19 & 0,13 & 1,72 & 0,09 \\
VB 11 // MSE & 4,05 & 0,13 & 1,69 & 0,08 \\
\hline \hline
\end{tabular}

Comparando a tabela 13 com as tabelas 11 e 12, observou-se a diferença de tamanhos entre conídios e núcleos haplóides e diplóides. Os conídios e núcleos diplóides são maiores que os haplóides, respeitando a proporção sugerida por Roper (1952). 


\subsubsection{Haploidização}

A obtenção de segregantes a partir de diplóides ocorre espontaneamente durante as susceptíveis repicagens, isto devido a perdas cromossômicas espontâneas que ocorrem durante as divisões mitóticas. (Kafer, 1960; Clutterbuck, 1996). Para acelerar o processo de haploidização, diversos agentes químicos e físicos têm sido testados. Os agentes mais utilizados são os químicos, onde se destacam: $\rho$ - fluorfenilalanina ( $\rho$ FA)(Morpurgo, 1961; Lhoas, 1961), benomil (Hastie, 1970), cloroneb (Paccola, 1982) e Nglycosyl polifungin (Bal et al, 1975).

Paccola (1982) utilizou três agentes haploidizantes, $\rho$-FA, benlate e cloroneb em cruzamentos com linhagens deterioradas provenientes da linhagem $\mathrm{A}$. $\mathrm{O}$ cloroneb não demostrou ser um bom agente haploidizante, uma vez que aumenta a freqüência de permutas mitóticas. As linhagens com duplicação cromossômicas, portanto, ficam mais susceptíveis a esse agente, ocorrendo um aumento na taxa de crossing-over, alterando a instabilidade (Nga \& Roper, 1969). Estudos realizados por Pizzirani-Kleiner (1981) e Monteiro (1989) demostraram que o cloroneb seleciona algumas marcas, como a galactose e riboflavina, além de ser seletivo para mapear o gene bncA1, selecionando apenas setores haplóides pyroA4. Sendo a localização do gene bncA1 determinada por $\rho-$ FA, encontrando-se no grupo de ligação IV.

Segundo Menezes (1974), Pizzirani-Kleiner (1981), Paccola (1982) e Pascon (1994), o uso do $\rho$-FA como agente haploidizande demostrou melhor eficiência, inclusive com o aparecimento de setores deteriorados. $\mathrm{O}$ motivo desse agente haploidizante não ter sido utilizado neste trabalho foi devido à indisponibilidade da droga.

Bal et al (1975) realizaram estudos com o N-glycosyl - polifungin em colônias diplóides de $A$. nidulans, obtendo resultados efetivos na seleção de recombinates mitóticos para o estudo de ligações. Esse agente haploidizante, não foi utilizado neste trabalho devido à sua indisponibilidade. 
O agente haploidizante benlate foi a opção escolhida devido à sua disponibilidade. Estudos realizados por Favraud (1984); Paccola (1982), Queiroz (1988) e Pascon (1994) demostraram que o benlate provoca uma queda na proporção de setores haplóides deteriorados, sendo que isso pode estar relacionado com algum tipo de inibição que ocorra nesse tipo de setor, sendo seu desenvolvimento impedido pelo fungicida ou ainda ocorre um menor valor adaptativo em relação a outros segregantes. Neste trabalho, esse efeito de diminuição de setores deteriorados não foi observado tão drasticamente, sendo necessário para prosseguir esde estudo utilizar outros agentes haploidizantes para fins de comparação.

Foi utilizado o benlate na concentração de $1,4 \mu \mathrm{g}$ por $\mathrm{mL}$ de meio completo. Na tabela 14, é possível observar os resultados obtidos nos diferentes cruzamentos. O cruzamento MSE//bi meth foi utilizado como padrão.

Tabela 14. Total de setores obtidos por benlate e purificados dos cruzamentos.

\begin{tabular}{cccc}
\hline \hline Cruzamentos & $\begin{array}{c}\text { Número de colônias } \\
\text { diplóides inoculadas }\end{array}$ & $\begin{array}{c}\text { Total de setores } \\
\text { obtidos }\end{array}$ & $\begin{array}{c}\text { Total de setores } \\
\text { purificados }\end{array}$ \\
\hline bi meth //MSE & 104 & 130 & 123 \\
VB 7// MSE & 72 & 32 & 26 \\
VB 8// MSE & 72 & 33 & 27 \\
VB 9// MSE & 208 & 34 & 13 \\
VB 10// MSE & 72 & 30 & 26 \\
VB 11// MSE & 408 & 9 & 0 \\
\hline \hline
\end{tabular}

A haploidização e purificação dos segregantes das linhagens deterioradas foram extremamente trabalhosas, devido ao pequeno tamanho que os setores emitidos, isso possivelmente em decorrência da duplicação cromossômica.

Tentou-se utilizar outro método de haploidização, através de radiação ultra-violeta aplicada diretamente nas colônias diplóides por cinco segundo após inoculação em placa de Petri com meio completo (Rocha, comunicação pessoal). Esse método foi 
aplicado apenas para os cruzamentos VB 9 // MSE e VB $11 / /$ MSE, que apresentaram menor quantidade de setores segregantes obtidos por benlate. Os resultados dos segregantes haplóides obtidos por radiação U.V. encontram-se na Tabela 15.

Tabela 15. Total de setores obtidos por radiação U.V. e purificados dos cruzamentos.

\begin{tabular}{|c|c|c|c|}
\hline Cruzamentos & $\begin{array}{l}\text { Número de colônias } \\
\text { diplóides inoculadas }\end{array}$ & $\begin{array}{c}\text { Total de setores } \\
\text { obtidos }\end{array}$ & $\begin{array}{c}\text { Total setores } \\
\text { purificados }\end{array}$ \\
\hline bi meth//MSE & 64 & 4 & 2 \\
\hline VB 9//MSE & 96 & 40 & 11 \\
\hline VB $11 / / \mathrm{MSE}$ & 96 & 2 & 0 \\
\hline
\end{tabular}

Os resultados obtidos por haploidização com radiação U.V. foram pequenos quando comparados com o agente químico benlate. Além disso, os segregantes haplóides do cruzamento VB 9 // MSE apresentaram um número alto de colônias prototróficas, sendo os dados da análise mitótica não conclusivos. Para a obtenção de dados conclusivos, sugerem estudos mais detalhados e rigorosos sobre os efeitos da haploidização com radiação U.V., uma vez que essa fonte de mutagenisidade causa quebras cromossômicas, podendo afetar mais intensamente as linhagens com duplicação cromossômica.

\subsubsection{Análise Mitótica}

Os dados referentes à análise mitótica dos segregantes haplóides obtidos por benlate encontra-se na Tabela 16. A análise mitótica do variante deteriorado VB 11 não foi realizada devido à ausência de segregantes haplóides.

Na tabela 17 , observam-se os resultados referentes à localização do variante de deterioração dos cruzamentos. 
Tabela 16. Análise Genética Mitótica dos Cruzamentos

\begin{tabular}{|c|c|c|c|c|c|c|c|c|c|}
\hline \multirow{2}{*}{$\begin{array}{l}\text { Grupo de } \\
\text { Ligação }\end{array}$} & \multirow{2}{*}{$\begin{array}{c}\text { Marcadores } \\
\text { Genéticos }\end{array}$} & \multicolumn{2}{|c|}{ VB 7} & \multicolumn{2}{|c|}{ VB 8} & \multicolumn{2}{|c|}{ VB 9} & \multicolumn{2}{|c|}{ VB 10} \\
\hline & & $\mathrm{N}$ & D & $\mathrm{N}$ & D & $\mathrm{N}$ & D & $\mathrm{N}$ & $\mathrm{D}$ \\
\hline \multirow[t]{2}{*}{ I } & pro $^{+}$paba $^{+}$ & 14 & 6 & 20 & 2 & 10 & 3 & 14 & 10 \\
\hline & pro $^{-}$paba ${ }^{-}$ & 4 & 2 & 2 & 3 & 0 & 0 & 1 & 1 \\
\hline \multirow[t]{2}{*}{ II } & $\mathrm{W}^{+}$ & 12 & 2 & 15 & 1 & 3 & 0 & 9 & 2 \\
\hline & $\mathrm{w}^{-}$ & 6 & 6 & 7 & 4 & 7 & 9 & 6 & 9 \\
\hline \multirow[t]{2}{*}{ III } & $\mathrm{Gal}^{+}$ & 0 & 1 & 0 & 4 & 7 & 3 & 0 & 3 \\
\hline & $\mathrm{Gal}^{-}$ & 18 & 7 & 22 & 1 & 3 & 0 & 15 & 8 \\
\hline \multirow[t]{2}{*}{ IV } & Pyro $^{+}$ & 1 & 8 & 1 & 3 & 10 & 3 & 0 & 3 \\
\hline & Pyrol $^{-}$ & 17 & 0 & 21 & 2 & 0 & 0 & 15 & 8 \\
\hline \multirow[t]{2}{*}{ V } & $\mathrm{Fac}^{+}$ & 0 & 1 & 0 & 1 & 0 & 3 & 1 & 2 \\
\hline & $\mathrm{Fac}^{-}$ & 18 & 7 & 22 & 4 & 10 & 0 & 14 & 9 \\
\hline \multirow[t]{2}{*}{$\mathrm{VI}$} & $\mathrm{S}^{+}$ & 7 & 6 & 15 & 4 & 9 & 3 & 11 & 8 \\
\hline & $\mathrm{s}^{-}$ & 11 & 2 & 7 & 1 & 1 & 0 & 4 & 3 \\
\hline \multirow[t]{2}{*}{ VII } & $\mathrm{Nic}^{+}$ & 11 & 4 & 7 & 2 & 10 & 2 & 1 & 10 \\
\hline & $\mathrm{Nic}^{-}$ & 7 & 6 & 15 & 3 & 0 & 1 & 14 & 1 \\
\hline \multirow[t]{2}{*}{ VIII } & $\mathrm{Ribo}^{+}$ & 14 & 5 & 15 & 3 & 9 & 2 & 11 & 8 \\
\hline & Ribo $^{-}$ & 4 & 3 & 7 & 2 & 1 & 1 & 4 & 3 \\
\hline Total & & 18 & 8 & 22 & 5 & 10 & 3 & 15 & 11 \\
\hline
\end{tabular}

$$
\begin{aligned}
& \mathrm{N}=\text { normal } \\
& \mathrm{D}=\text { deteriorado }
\end{aligned}
$$


Tabela 17. Localização dos determinantes de deterioração nos grupos de ligação.

\begin{tabular}{cc}
\hline \hline Determinante de Deterioração & Grupo de Ligação \\
\hline VB 7 & IV \\
VB 8 & III \\
VB 9 & V \\
VB 10 & VII \\
VB 11 & $*$ \\
\hline
\end{tabular}

* não foi possível determinar a localização do determinante de deterioração.

\subsubsection{Análise Meiótica}

Em Aspergillus nidulans, a diferenciação dos ciclo sexual não é comumente encontrado na natureza sendo induzida. Para isto, basta proporcionar ao fungo algumas situações de estresse onde esse imediatamente responde com a formação de estruturas reprodutivas do ciclo sexual.

Para testar a localização dos determinantes de deterioração realizada via ciclo parassexual com os marcadores auxotróficos, procedeu-se os cruzamentos dos variantes deteriorados com a linhagem testadora MSE. Após induzir a heterocariose, vedou-se a placa de Petri com fita adesiva, provocando estresses por baixa tensão de oxigênio no interior da placa (Pontecorvo et al, 1954). Essas placas permaneceram incubadas por 12 dias a $37^{\circ} \mathrm{C}$. Após esse período, foi possível observar os cleistotécios. Analisando na lupa os cleistotécios formados dos cruzamentos bi meth x MSE, VB 7 x MSE, VB 8 x MSE, VB 9 x MSE, VB 10 x MSE, VB 11 x MSE, observaram-se alguns detalhes interessantes, como exemplo a quantidade de cleistotécios menor na linhagens 
deterioradas, quando comparadas com a linhagem padrão, além de possuírem um tamanho reduzido.

Pascon (1994) obteve uma alta taxa de cleistotécios abortivos, com os cruzamentos com variantes deteriorados originários da linhagem Abnc, o que não ocorreu neste trabalho, sendo obtidos cleistotécios híbridos procedendo à análise sexual dos cruzamentos.

Os dados da segregação meiótica encontram-se na tabela 18. A proporção esperada de segregantes normais e deteriorados foi de $1: 1$, sendo aplicado o teste de $\mathrm{x}^{2}$ para detectar se os desvios encontrados ocorrem ao acaso. Caso essas proporções não fossem seguidas, o teste de $\mathrm{x}^{2}$ foi aplicado à proporção de $2: 1$. Na tabela, 19 encontram-se os dados referentes às análises dos variantes deteriorados. Foi considerada ligação entre os marcadores genéticos quando a freqüência de recombinação entre eles foi menor que $40 \%$.

Tabela 18. Teste de $x^{2}$ para os cruzamentos analisados

\begin{tabular}{cccccc}
\hline Cruzamentos & \multicolumn{2}{c}{ Segregantes } & Total & \multicolumn{2}{c}{$\mathrm{X}^{2}$} \\
& normal & deteriorado & & $1: 1$ & $2: 1$ \\
\hline VB 7 x MSE & 68 & 32 & 100 & $12,96^{*}$ & $2,613^{\mathrm{n} / \mathrm{s}}$ \\
VB 8 x MSE & 68 & 27 & 95 & $17,7^{*}$ & $0,596^{\mathrm{n} / \mathrm{s}}$ \\
VB 9 x MSE & 71 & 8 & 79 & $50,24^{* *}$ & $9,32^{*}$ \\
VB 10 x MSE & 33 & 17 & 50 & $5,12^{*}$ & $1,8^{\mathrm{n} / \mathrm{s}}$ \\
VB 11 x MSE & 43 & 29 & 72 & $2,72^{\mathrm{n} / \mathrm{s}}$ & $6,41^{*}$ \\
\hline \hline
\end{tabular}

$\alpha+5 \%$, com gl. $=1$

* significativo

** altamente significativo

n/s não significativo 
Tabela 19. Análise Meiótica dos cruzamentos

\begin{tabular}{cccccc}
\hline \hline Cruzamentos & $\begin{array}{c}\text { Grupo de } \\
\text { Ligação }\end{array}$ & $\begin{array}{c}\text { Marcador } \\
\text { Genético }\end{array}$ & \multicolumn{2}{c}{ Colônias } & $\begin{array}{c}\text { Freqüência de } \\
\text { recombinação }\end{array}$ \\
\hline VB 7 & IV & pyro $^{+}$ & 20 & 20 & 32,0 \\
nyro- & 48 & 12 & \\
VB 8 & III & gal $^{+}$ & 0 & 2 & 26,31 \\
& & gal $^{-}$ & 68 & 25 & \\
VB 9 & V & fac $^{+}$ & 0 & 3 & 6,32 \\
& & fac $^{-}$ & 73 & 5 & \\
VB 10 & VII & nic $^{+}$ & 4 & 7 & 26,0 \\
& & nic $^{-}$ & 30 & 9 & \\
\hline \hline
\end{tabular}

Os cruzamentos das variantes deteriorados VB 7, VB 8 e VB 10 apresentaram desvios significativos para a proporção 1 normal : 1 deteriorado. Apenas o cruzamento VB 9 apresentou desvios significativos para as duas proporções analisadas (1:1 e 2:1, normal - deteriorado). Paccola (1982) e Monteiro (1989), analisando cruzamentos com variantes deteriorados provenientes da linhagem $\mathrm{A}$, obtiveram resultados semelhantes, descrevendo que a presença de aberrações cromossômicas heterozigotas em cruzamentos, possuem como consequiência a produção de ascos com um número inferior a 8 ou ascos, contendo vários ou todos os ascósporos defectivos, sendo isso uma provável explicação para os desvios significativos encontrados para a segregação 1:1.

O cruzamento VB 11 // MSE não possibilitou a detecção do determinante de deterioração pelo ciclo parassexual, mas apresentou cleistotécios viáveis, sendo possível verificar a provável localização pelo ciclo sexual. Em análise estatística, observou-se que a proporção 1:1 deste cruzamento não foi significativa. A análise pelo ciclo sexual apresentou que o determinante de deterioração dessa linhagem encontra-se, provavelmente, no grupo de ligação $\mathrm{V}$ ligado ao marcador acetato com a freqüência de recombinação de $34,5 \%$, mas esses dados não são conclusivos para a precisa localização desse determinante de deterioração, sendo necessários estudos mais detalhados. 


\section{CONCLUSÃO}

O gene bncAl causa alterações morfológicas nas estruturas do conidióforo de $A$. nidulans como septação de fiálides, diminuição na quantidade de métulas e fiálides e formação de conídios bi e trinucleados. Todos os variantes deteriorados analisados, portadores e não portadores do gene $b n c \mathrm{~A} 1$, apresentam anormalidades na estrutura do conidióforo como alongamentos e indiferenciações de métulas e fiálides. Estas anormalidades podem estar relacionadas com os determinantes de deterioração.

A obtenção de setores haplóides durante a análise parassexual foi limitada, sugerindo-se uma ação estabilizadora parcial do gene bncA1, impedindo o pareamento entre homólogos e/ou restringindo a ocorrência de permutas durante o processo mitótico. Na análise genética sexual, a não constatação de proproção 1:1 entre segregantes normais:deteriorados sugere a interferência do gene bncAl ou do determinante de deterioração no processo meiótico. 


\section{REFERÊNCIAS BIBLIOGRÁFICAS}

ADAMS, T. H.; DEISING, H. \& TIMBERLAKE, W. E. brlA requires both zinc finger to induce development. Molecular Cellular Biology, v. 10, p. 1815-17. 1990.

ADAMS, T.H.; BOYLAN, M.T.; TIMBERLAKE, W.E. brlA is necessary and sufficient to direct conidiophore development in Aspergillus nidulans. Cell, v. 54, p. 353-62. 1988.

ADAMS, T.H.; WIESER, J. K. \& YU, J.H. Asexual sporulation in Aspergillus nidulans. Microbiology and Molecular Biology Reviews, v. 62, n. 1, p. 35-54. 1998.

ALEXOPOULO, C.G. Introductory mycology, 2. Nd. Ed. Wiley. New York. 613 p. 1962.

ASPIRON, D. A general system for the automatic selection of auxotrophs from prototrophic and vice versa in micro-organisms. Nature, v. 195, p. 959-961. 1962

AXELROD, D.E. Kinetics of differentiation of conidiophores and conidias by colonies of Aspergillus nidulans. Journal of General Microbiology, v. 73, p. 181-84, 1972.

AXELROD, D.E.; GEALT, M.; PASTUSHOK, M.; Gene control of developmental competence in Aspergillus nidulans. Developmental Biology, v 34, p. 9-15, 1973.

AZEVEDO, J.L \& SANTANA, E.P. The use of cloroneb to obtain haploid segregants from heterozygous diploid of Aspergillus nidulans. Aspergillus Newsletter, v. 13, p. 6. 1975.

AZEVEDO, J.L. \& COSTA, S.O.P. Exercícios Práticos de Genética. São Paulo. Ed. Nacional, 1973. 288p.

AZEVEDO, J.L. \& ROPER, J.A. Mitotic non-conformity in Aspergillus nidulans: successive and transposable genetic changes. Genetical Research, v. 16, p. 79-93. 1970.

AZEVEDO, J.L. Altered instability due to genetic changes in a duplication strain of Aspergillus nidulans. Genetical Research, v. 26, p. 55-61. 1975. 
AZEVEDO, J.L. Mitotic non-conformity in Aspergillus nidulans. Sheffield, 1971 p. 240. Tese $(\mathrm{PhD})$ - University of Sheffield.

AZEVEDO, J.L.; OLIVEIRA, A. \& ROCHA CAMPOS, A.J. Replicador multifio para transferência de esporos de fungos filamentosos. Summa Phytopathologia, v. 2, p. 237 41. 1976.

BAINBRIDGE, B.W. \& ROPER, J.A. Observations on the effects of a chromosome duplication in Aspergillus nidulans. Journal of General Microbiology, v. 42, p. 417-424. 1966.

BAL, J.; BARTNIK, E.; GORYLUK, B. \& PIENIAZEK, N.J. An easy of obtaining Aspergillus nidulans haploid in the parassexual cycle using $\mathrm{N}$-glycosul polifungin. Genetical Research, v. 25, p. 249-52. 1975.

BALL, C \& AZEVEDO, J.L. A "fluffy" mutant in Aspergillus nidulans. Aspergillus Newsletter, v. 5, p. 9. 1964.

BARNETT, W.E \& DE SERES. Fixed genetic instability in Neurospora crass. Genetics, v. 48, p. 717-23. 1963

BERGEN, L.G. \& MORRIS, N.R. Kinetics of nuclear division cycle of Aspergillus nidulans. Journal of Bacteriology, v. 156, p. 155-60. 1983.

BOYLAN, M.T.; MIRABITO, P.M.; WILLET, C.E.; ZIMMERMAN, C.R.; TIMBERLAKE, W.E. Isolation and physical characterization of three essential conidiation gene from Aspergillus nidulans. Molecular and Cellular Biology, v. 7, p. 3113-18. 1987.

BUSBY, B.M; MILLER, K.Y.; MILLER, B.L. Suppression and enhancement of the Aspergillus nidulans medusa mutation by altered dosage of the bristle and stunted genes. Genetics, v. 143, p 155-63. 1996.

BUTNICK, N.Z.; YAGER, L.N.; KURTZ, M.B.; CHAMPE, S.P. Genetic analysis of mutants of Aspergillus nidulans blocked at an early stage of sporulation. Journal of Bacteriology, $v$. 160, p. 541-45. 1984.

CASTRO-PRADO, M.A.A \& ROCHA, C.L.S. Cytological and Genetic characterization of a conidiogenesis mutants of Aspergillus nidulans. Cytologia, v. 63, p. 99-106. 1998.

CHAE, K.S; KIM, J.H.; CHOI, Y.; HAN, D.M. \& JAHNG, K.Y. Isolation and characterization of genomic DNA fragment complementing an nsd mutation of Aspergillus nidulans. Molecular Cells, v. 5, p. 146-50. 1995.

CHAMPE, S.P. \& EL-ZAYAT, A. Isolation of a sexual sporulation hormone from Aspergillus nidulans. J. Bacteriology, v. 171, p. 3982-88. 1989.

CHAMPE, S.P.;KURTZ, M; YAGER, I.; BUTNICK, N. \& AXELROD,D. Spore formation in Aspergillus nidulans: competence and other developmental processes. In.: The Fungal Spore Morphogenetic Control, ed. H.R. Hohl and G. Turian. Academic Press. New York. p.255-76. 1981. 
CHAMPE, S.P; RAO, P. \& CHANG, A. An endogenous induced of sexual developmental in Aspergillus nidulans. Journal of General Microbiology, v. 133, p. 1383-87. 1987.

CHANG, Y.C. \& TIMBERLAKE, W.E. Identification of Aspergillus brl A response elements (BREs) by genetic selection in yeast. Genetics, v. 135, p. 29 - 38. 1992.

CLUTTERBUCK, J. \& SPATHAS, D.H. Genetic and environmental modification of gene expression in the brl A12 variegated position effect mutants of Aspergillus nidulans. Genetical Research, v. 43, p. 123-38. 1984.

CLUTTERBUCK, J. \& TIMBERLAKE, W.E. Genetic regulation of sporulation in the fungus Aspergillus nidulans. In. RUSSO, V.E.A.; BRODY, S.; COVE, D; OTTOLENGHE, S. ed. Development. London: Spring-Verlag, cap 7, p. 103-18. 1992.

CLUTTERBUCK, J. A mutational analysis of conidial development in Aspergillus nidulans. Genetics, v. 63, p. 317-27. 1969.

CLUTTERBUCK, J. A variegated position effect in Aspergillus nidulans. Genetical Research, v. 16, p. 303-16. 1970.

CLUTTERBUCK, J. Parassexual recombination in fungi. Journal Genetical, v. 75, n. 3, p. 28186. 1996.

CLUTTERBUCK, J. Synchronous nuclear division and septation in Aspergillus nidulans. Journal of General Microbiology, v 60, p. 133-35. 1970.

CLUTTERBUCK, J. The genetics of conidiation in Aspergillus nidulans. In Genetics and Physiology of Aspergillus, ed. J.A. Paterman and J.E. Smith. Academic Press. New York pp 305-317. 1977.

CLUTTERBUCK, J. The genetics of conidiation pigmentation in Aspergillus nidulans. Journal of Genetical Microbiology, v 136, p. 1731-38. 1990.

CLUTTERBUCK, J. The validity of the Aspergillus nidulans linkage Map. Fungal Genetics and Biology, v. 21, p. 267-77. 1997.

DUTTON, J.R.; JOHNS, S. \& MILLER, B. StuAp is a sequence-specific transcription factor that regulation developmental complexity in Aspergillus nidulans. The EMBO Journal, v. 16, n. 18, p. $5710-21.1997$.

EIDAM, E. Zur Kenntniss der entwicklung ber den Ascomyceten III. Sterigmatocystis nidulans n. sp. Cohn. Buth. Biolo, pfk, v. 3, p. 392-411, 1883.

ELLIOT, C.G. The cytology of Aspergillus nidulans. Genetical Research, v. 1, p. 462-76. 1960.

FAVRAUD, L. Instabilidade mitótica em Aspergillus nidulans com duplicação cromossômica. Piracicaba, 1984. 160 p. (Doutorado - Escola Superior de Agricultura Luíz de Queiroz ESALQ/USP). 
GIANCOLI, A.C.H.; PASCON, R.C.; PIZZIRANI-KLEINER, A.A. \& KITAJIMA, E.W. Caracterização de variantes deteriorados de aspergillus nidulans via microccopia eletrônica de varredura. Revista Brasileira de Genética, v. 20, n. 3, p. 290, 1997. Suplemento./Apresentado ao 43. Congresso Nacional de Genética, Goiânia, 1997 Resumo/

GIMENO, C.J.; LJUNDGAHL, P.; STYLES, C.A. \& FINKS, G.R. Unipolar cell divisions in the yeast $S$. cerevisae lead to filamentous growth: regulation by starvation and Ras. Cell, v 68, p 1077-90, 1992.

GOODAY, G.W. The hyphae tip. In: SMITH, J.E. Fungal Differentiation. A Contemporary Synthesis. New York, Dekker, 1983. p. 315-356.

HAN, D.M.Y.; HAN, J.H.; KIM, K.Y.; JAHNG, Y.S.; CHUNG, J.H.; CHUNG, J. \& CHAE, K.S. Isolation and characterization do NSD mutants in Aspergillus nidulans. Kor. Journal Mycology, v. 22, p. 1-7. 1994.

HAN, D.M.Y.; HAN, J.H.; LEE, K. J.; JAHNG, K.S. \& CHAE, K.S. Inhibitory conditions of asexual developmental and their application for the screening of mutants defective in sexual developmental. Kor. Journal Mycology, v. 18, p. 225-232. 1990.

HAN, S.; NAVARRO, J.; GREVE, R.A.; ADAMS, T.H. Translation repression of brlA expression prevents premature developmental in Aspergillus. The EMBO Journal, v. 12, p. $2439-48,1993$.

HARRIS, S.D. \& KRAUS, P. Regulation of septum formation in Aspergillus nidulans by a DNA damages checkpoint pathway. Genetics, v. 148, p. 1055-67. 1998.

HASTIE, A.C. Benlate - induced instability of Aspergillus diploids. Nature, v. 226, p. 771. 1970.

HERMAN, L; KURTZ, M. \& CHAMPE, S. Laccase localized in Hülle cells and cleistothecial primorfia of Aspergillus nidulans. J. Bacteriology, v. 154, n² 2, p. 955-64. 1983.

JOHNSTONE, J.L.; HUGHES, S.G.; CLUTTERBUCK, A.J. Cloning an Aspergillus nidulans developmental gene by transformation. The EMBO Journal, v. 4, 1307-12. 1985.

KÄFER, E. High frequency of spontaneous and induced somatic segregation in Aspergillus nidulans. Nature, v. 186, p. 619-620. 1960.

KÄFER, E. The process of spontaneous recombination on in vegetative e nuclei of Aspergillus nidulans. Genetics, v. 46, p. 1581-09. 1961

KIRK, K.E \& MORRIS, N. The tub-B alfa tubulin gene is essential for sexual development in Aspergillus nidulans. Genes \& Developmental, v. 5, p. 2014-23. 1991. 
LAW, D.J. \& TIMBERLAKE, W.E. Developmental regulation of lacase level in Aspergillus nidulans. Journal of Bacteriology, v. 144, p. 509-17. 1980.

LEE, B.N \& ADAMS, T.H. The Aspergillus nidulans flu $\mathrm{G}$ gene is required for production of an extracelular developmental signal. Genes and Development, v. 8, p. 641-51, 1994.

LHOAS, P. Mitotic haploidization by treatment of Aspergillus niger diploids with $p$ fluorfenilalanina. Nature, v. 190, p. 744. 1961.

LIEBER, M.M. The effects of temperature on genetic instability in Aspergillus nidulans. Mutation Research, v. 34, p. 93-122. 1976.

LUNA, E.A. Características citológicas e genéticas de linhagens selvagens, mutantes e diplóides de Metarhizium anisopliae (Metsch.) Sorokin. Rio de Janeiro, 1985. 259p. (Doutorado Universidade Federal do Rio de Janeiro).

MARSHALL, M.A. \& TIMBERLAKE, W.E. Aspergillus nidulans wetA regulates sporespecific gene expression. Molecular and Cellular Biology, v. 11, p. 55-62, 1991.

MARTINELLI, S.D. \& CLUTTERBUCK, J.A quantitative survey conidiation mutants in Aspergillus nidulans. Journal of General Microbiology, v. 69, p. 261-68. 1971.

MAZUR, P. MEYERS, H.V. \& NAKANISHI, K. Structural elucidation of sporogenic fatty acid metabolites from Aspergillus nidulans Tetrahedron Letters, v. 27, p. 3837-40. 1990.

McCULLY, KS \& FORBES, E. The use of p-fluorphenilalanine with "master" strain of Aspergillus nidulans form assigning gene of to linkage groups. Genetical Research, v. 6, p. 352-59. 1965.

MENEZES, E.M. Análise genética de variantes deteriorados e suas reversões em Aspergillus nidulans (Eidam) Winter. Piracicaba, 1974. p. 141 (Mestrado- Escola Superior de Agricultura Luíz de Queiroz - ESALQ/USP).

MILLER, B.L. The developmental genetics of asexual reproduction in Aspergillus nidulans. Developmental Biology, v. 1, p. 207-19. 1990.

MILLER, B.L., MILLER, K.Y. \& TIMBERLAKE, W.E Direct and indirect gene replacements in Aspergillus nidulans. Molecular Cell Biology, v. 5, p. 1714-21. 1985.

MILLER, K.Y.; WU, J.; MILLER, B.L. Stu A is required for cell pattern formation in Aspergillus. Genes and Development, v. 6, p. 1770-82. 1992.

MIMS, C.W.; RICHARDSON, E.A.; TIMBERLAKE, W.E. Ultrastructural analysis of conidiophore development in the fungus Aspergillus nidulans using freeze-substitution. Protoplasma, v. 144, p. 132-41, 1988.

MIRABITO, P.M.; ADAMS, T.H.; TIMBERLAKE, W.E. Interaction of three sequentially expressed gene control temporal and spatial specificity in Aspergillus development. Cell, v. 57, p. 859-68. 1987. 
MOLINA, S.M.G. \& AZEVEDO, J.L. Estudos da fenocópia em variantes deteriorados de Aspergillus nidulans. In. Reunião anual da Sociedade Brasileria para o Progresso da Ciência, 41, Fortaleza, 1989. Resumos. Fortaleza SBPC, 1989, p728.

MOLINA, S.M.G. Estudo de fenocópias em variantes com determinantes de deterioração em Aspergillus nidulans. Piracicaba, 1993. 274 p. (Mestrado - Escola Superior de Agricultura Luíz de Queiroz - ESALQ/USP).

MONTEIRO, C.B. Avaliação da instabilidade mitótica de Aspergillus nidulans através de técnicas genética clássicas e fussão de protoplastos. Piracicaba, 1989. 135 p. (Mestrado Escola Superior de Agricultura Luíz de Queiroz - ESALQ/USP).

MOONEY, J.L \& YAGER, L.N. Light is required of conidiation in Aspergillus nidulans. Genes and Development, v. 4, p. $1473-82.1990$.

MOONEY, J.L.; HASSETT, D.E.; YAGER, L.M. Genetic analysis of suppressors of the veA1 mutation in Aspergillus nidulans. Genetics, v. 126, p. 869-74. 1990.

MORPURGO, G. Research in Aspergillus nidulans genetics. Genetica, v. 94, p 283-89. 1994.

MORPURGO, G. Somatic segregation induced by p-fuorphenylalanine. Aspergillus Newsletter, v. 2, p. 10. 1961.

MORRIS, N.R. Mitotic mutants of Aspergillus nidulans. Genetical Research, v. 26, p 237 - 54. 1976.

NGA, B.H. \& ROPER, J.A A chromosomal process giving rise vegetative instability in Aspergillus nidulans. Heredity, v. 21, p. 530-31. 1966

NGA, B.H. \& ROPER, J.A. A system generation spontaneous in intrachromosomal changes at mitosis in Aspergillus nidulans. Genetical Research, v. 14, p. 63-70. 1969.

NGA, B.H. \& ROPER, J.A. Quantitative intrachromosomal changes arising at mitosis in Aspergillus nidulans. Genetics, v. 5, p. 193-209. 1968

NIFFINEGGER E SOUZA. Aspectos genéticos e citológicos da instabilidade mitótica em Aspergillus nidulans. . Piracicaba, 1979. 224 p. (Mestrado - Escola Superior de Agricultura Luíz de Queiroz - ESALQ/USP).

O'HARA, E.B. \& TIMBERLAKE, W.E. Molecular characterization of the Aspergillus nidulans yA locus. Genetics, v. 121, p. 249-54. 1989.

OEKLEY, B.R. Gamma-tubulin, the microtubule organiser? Trends in Cellular Biology, v. 2, p. 1-5. 1992.

OLIVEIRA, F.M. Análise de setores melhorados de Aspergillus nidulans. p. 101. 1982. (Doutorado - Escola Superior de Agricultura "Luíz de Queiroz" ESALQ/USP). 
OLIVER, P.T. Conidiophore and spore developmental in Aspergillus nidulans. Journal of General Microbiology, v. 73, p. 45-54, 1972.

PACCOLA, Estudos genéticos e citológicos em variantes deteriorados de Aspergillus nidulans. Piracicaba, 1982. 131 p. (Mestrado - Escola Superior de Agricultura Luíz de Queiroz ESALQ/USP).

PAES BARROS, J. Análise citogenética de algumas linhagens de Aspergillus nidulans (Eidam) Winter. Piracicaba, 1977. 81 p. (Mestrado - Escola Superior de Agricultura Luíz de Queiroz - ESALQ/USP).

PASCON, R.C. Isolamento e caracterização de setores deteriorados da linhagem Abnc de Aspergillus nidulans. Piracicaba, 1994. 140 p. (Mestrado - Escola Superior de Agricultura Luíz de Queiroz - ESALQ/USP).

PASTUSHOK, M. \& AXELROD, D.E. Effect of glucose, ammonium and medio maintenance initiation by colonies of Aspergillus nidulans. Journal of General Microbiology, v. 94, p. 221-24. 1976.

PIZZIRANI, A.A. Características, propriedades e estabilização de dissômicos em Aspergillus nidulans. Piracicaba, 1977. 111 p. (Mestrado - Escola Superior de Agricultura Luíz de Queiroz - ESALQ/USP).

PIZZIRANI-KLEINE, A.A.; PEREIRA, J.; AZEVEDO, J.L. Genética de fungos no laboratório. Série Fundamentos de Biotecnologia. Ed. Univ. Manaus. 1998

PIZZIRANI-KLEINER, A.A. \& AZEVEDO, J.L. Characterization and genetical analysis of an Aspergillus nidulans strain that produces mutinucleate conidia. Transaction of the British Mycological Society, v. 86, p. 123-130. 1986a.

PIZZIRANI-KLEINER, A.A. \& AZEVEDO, J;L. Effect of the bncA gene on the instability of Aspergillus nidulans. Genetical Research, v. 48: p. 145-150, $1986 \mathrm{~b}$.

PIZZIRANI-KLEINER, A.A. Efeito do gene bncAl na formação de conídios de Aspergillus nidulans. Piracicaba, 1981. 141 p. (Doutorado - Escola Superior de Agricultura Luíz de Queiroz - ESALQ/USP).

PONTECORVO, G. Auxanographic techniques in biochemical genetics. Journal of General Microbiology, v3, p. 122-26. 1949b.

PONTECORVO, G. Non random distribution of multiple mitotic crossing-over among nuclei of heterozygous diploid Aspergillus. Nature, v. 170, p. 204, 1952.

PONTECORVO, G. The genetical control of nutritional requirements in microorganisms and its application to microbiological assays. Proceedings of Nutrition, v. 5, p. 182-86. 1946

PONTECORVO, G.; ROPER, J.A.; HEMMONS, L.M.; MacDONALD, K.D.; BUFTON, A.W.J. The genetics of Aspergillus nidulans. Advances in Genetics, v. 5, p. 141-238. 1953. 
PONTECORVO, G.; TAN-GLOOR, E; FORBES, E. Analysis of mitotic recombination in Aspergillus nidulans. Journal of Genetics, v. 52, p. 226-37. 1954.

PRADE, R.A. \& TIMBERLAKE, Q.E. The Aspergillus nidulans brlA regulatory locus consists of overlapping transcription units that are individually required for conidiophore development. The EMBO Journal, v. 12, p. 2439-48. 1993.

QUEIROZ, M.V. O efeito da protoplastização na instabilidade Mitótica de Aspegillus nidulans. Piracicaba, 1988. 136 p. (Mestrado - Escola Superior de Agricultura Luíz de Queiroz ESALQ/USP).

ROBERTS, C.F. A replica plating technique for the isolation of nutritionally is exacting mutants of a filamentous fungus (Aspergillus nidulans). Journal of General Microbiology, v. 20, p. 540-48. 1959.

ROCHA, C.L.M.S.C. Caracterização citológica, genética e molecular de um mutante para conidiogenese em Aspegillus nidulans. Piracicaba, 1997. 202 p. (Doutorado - Escola Superior de Agricultura Luíz de Queiroz - ESALQ/USP).

ROPER, J.A. Production of heterozygous diploids in filamentous fungi. Experientia, v. 8, p 1415. 1952.

ROPER, J.A.; PALMER, H.M. \& WATMOUGH, W.A. Mitotic non-conformity in Aspergillus nidulans : the effects of caffeine. Molecular General Genetics, v. 118, p. 125-33. 1972.

SAXENA, F.H.J. \& SINHA. V. Conidiation of Aspergillus nidulans in submerged liquid culture. Journal of General and Applied Microbiology, v. 19, p. 141-46. 1973.

SCHERER, S. \& DAVIS, R. Replacement of chromosome segments with altered DNA sequences constructed in vitro. Proc. Nat. Acad. Sci. USA, v. 76, p. 4951-55. 1979.

SESSO, Fixação de Sistemas Biológicos. In. SOUZA. W. Manual sobre técnicas básicas em microscopia eletrônica. Volume I. Técnicas Básicas. Sociedade Brasileira de Microscopia Eletrônica, p.105. 1989.

SEWALL, T.C.; MIMS, C.W.; TIMBERLAKE, W.E. aba A control phialides differentiation in Aspergillus nidulans. Plant Cell, v. 2, p. 731-39. 1990.

TAMAME, M. \&SANTOS, E. Demonstration of 5 methyl cytosine occurrence in the genome of Aspergillus nidulans Cellular Biochemistry, v. 13, p 214, 1988.

TAMAME, M.; ANTIQUERA, F.; VILLANUEVA, J. R. \& SANTOS, T. High-frequency conversion o a "fliffy" developmental phenotype in Aspergillus nidulans by 5-azacytidine treatment: evidence for involvement of a single nuclear gene. Molecular and Cellular Biology, v 3, p. 2287-97. 1983.

TIMBERLAKE, W.E. \& CLUTTERBUCK, A. Genetic Regulation of Conidiation. In: MARTINELLI, S.D. \& KINGHORN, J.R. Aspergillus 50 years on. 1994. vol. 29, cap. 16, p.383-427. 
TIMBERLAKE, W.E. Molecular genetics of Aspergillus nidulans development. Annual Review of Genetics, v. 24, p. 5-36. 1990.

YAGER, L.N. Early developmental events during asexual and sexual sporulation in Aspergillus nidulans. In.: BENNETT, J.W. \& KLEIN, M.A. Aspergillus: Biology and Industrial Applications. Slonehom, Butterwourth - Heinemann, 1992. p. 19-41.

YELTON, M.M; TIMBERLAKE, W.E.; VAN DEN HONDEL, C.A.M.J.J. A cosmid for selecting genes by complementation in Aspergillus nidulans: selection of the developmentally regulated yA locus. Proceedings of the National Academy of Science, v. 82, p. 834-38. 1985. 
ANEXO A.

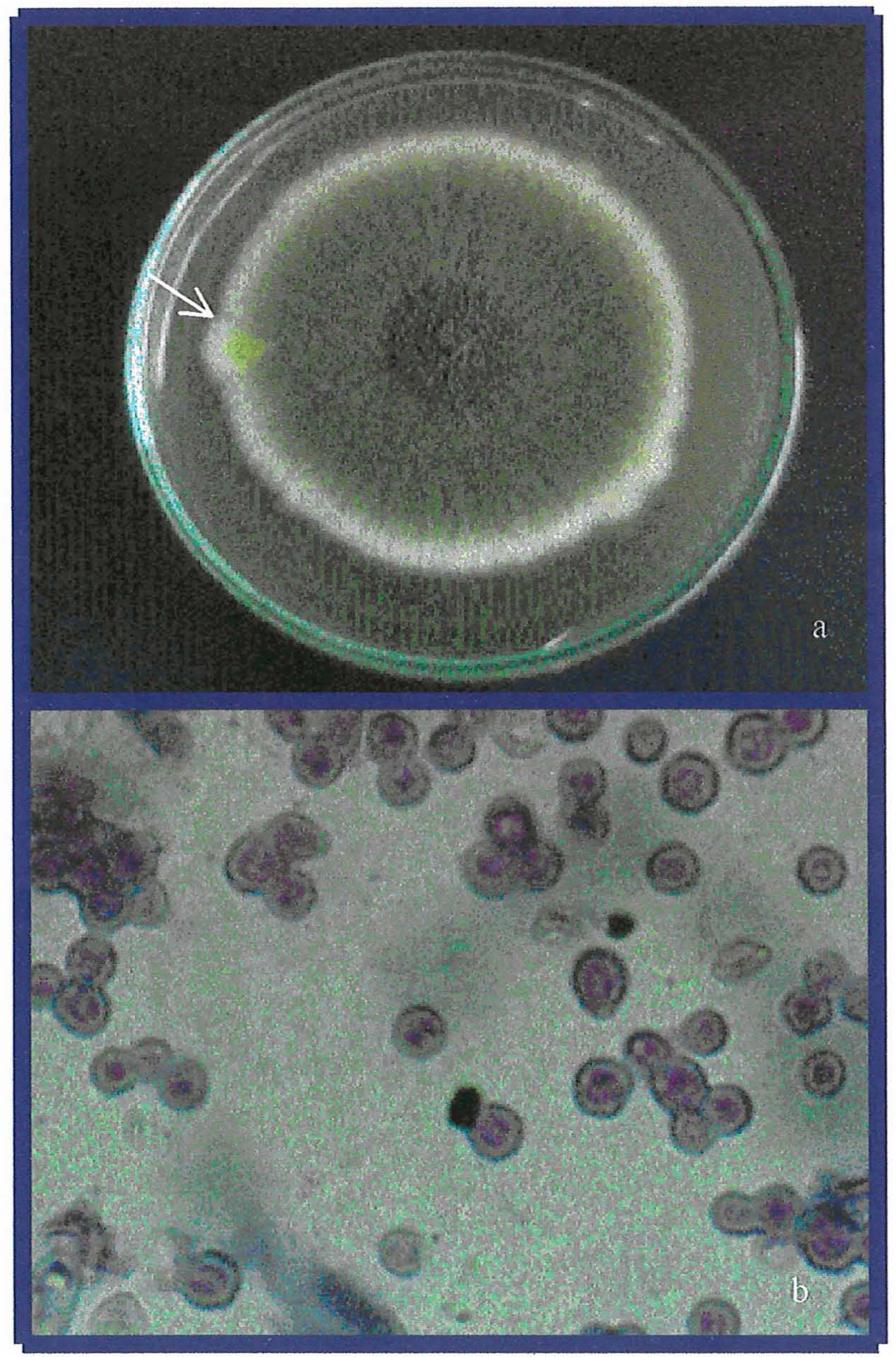

Figura a Linhagem A com detalhe da emissão de Setor melhorado (indicado com uma seta na figura). b. micrografia de conídios uni e binucleados da linhagem Abnc. 